\title{
AVALIAÇÃO DA QUALIDADE DOS NÉCTARES COMUM E DIETÉTICO DE MORANGO DAS VARIEDADES GUARANI E OSO GRANDE
}

\section{LÚCIA CRISTINA COSTA NOVAES}

Engenheiro Agrônomo

Orientador: Prof. Dr. JOÃO NUNES NOGUEIRA

\begin{abstract}
Dissertação apresentada à Escola Superior de Agricultura "Luiz de Queiroz", Universidade de São Paulo, para obtenção do título de Mestre em Ciências, Área de Concentração: Ciência e Tecnologia de Alimentos.
\end{abstract}

\author{
PIRACI C A B A \\ Estado de São Paulo - Brasil \\ Novembro - 1997
}


Dados Internacionais de Catalogação na Publicação (CIP)

DIVISÃo DE BIBLIOTECA E DOCUMENTAÇÃO - Campus "Luiz de Queiroz"/USP

Novaes, Lúcia Cristina Costa

Avaliação da qualidade dos néctares comum e dietético de morango das variedades Guarani e Oso Grande / Lúcia Cristina Costa Novaes. - - Piracicaba, 1997. $119 \mathrm{p}$.

Dissertaçāo (mestrado) - - Escola Superior de Agricultura Luiz de Queiroz, 1997. Bibliografia.

1. Nectar de morango (qualidade) 2. Tecnologia de alimento I. Título

CDD 664.8 


\section{AVALIAÇÃO DA QUALIDADE DOS NÉCTARES COMUM E DIETÉTICO DE MORANGO DAS VARIEDADES GUARANI E OSO GRANDE}

Lúcia Cristina Costa Novaes

Aprovada em: 19.12.1997

Comissão julgadora:

Prof. Dr. João Nunes Nogueira ESALQ/USP

Prof. Dra. Marília Oetterer ESALQ/USP

Prof. Dra. Rachel Elisabeth Domarco CENA

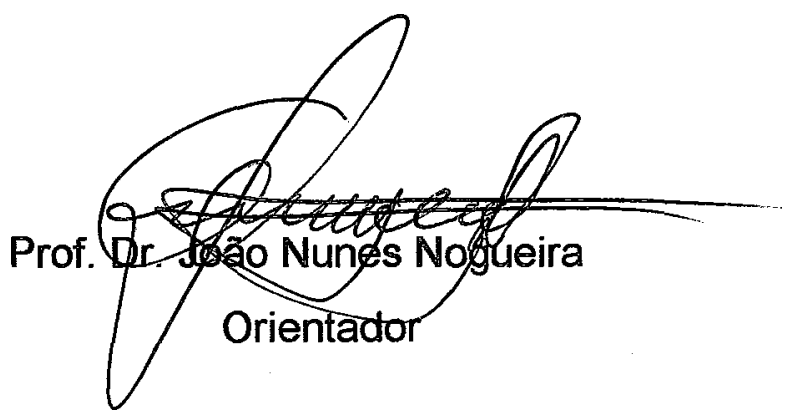


Agradeço a Deus pela fé na vida.

A toda minha família, em especial, meu marido Alexandre, pais, Fernando e Elisabete e irmãos, Paulo André e Ana Paula com muito amor, dedico. 


\section{AGRADECIMENTOS}

- Ao Prof. Dr. João Nunes Nogueira, pela orientação e colaboração na realização deste trabalho.

- Ao corpo docente do Curso de Mestrado, pelos valiosos ensinamentos.

- À Engenheira Agrônoma Regina Pires, e Técnico Agrícola Pereira, pelo auxílio na obtenção da matéria- prima utilizada neste trabalho.

- Aos produtores de morango, Srs. Oswaldo e Benedito Maziero, pela doação da matéria-prima necessária à realização deste trabalho.

- À Prof. Dra. Sônia Maria D. Stéfano Piedade, pela preciosa ajuda nas análises estatísticas.

- Aos técnicos de laboratório do Departamento de Ciência e Tecnologia Agroindustrial, Ivani Aparecida Marchetto Moreno, Rosemary Leonessa S. Mandro e Sylvino Luiz Torrezan, pelo auxílio prestado nas análises laboratoriais.

- À Bibliotecária Beatriz Helena Giongo, pela revisão das referências bibliográficas.

- À Regina Lúcia de Mello Lourenço, secretária da pós-graduação, pelos serviços prestados durante o Curso de Mestrado. 
- Às secretárias do Departamento de Ciência e Tecnologia de Alimentos, Sandra de Marchi Vello e Márcia Regina Severino, pelos auxílios prestados.

- À equipe de análise sensorial.

- À Fundação de Coordenação de Aperfeiçoamento de Pessoal de Nível Superior (CAPES), pelo suporte financeiro.

- A Kátia Sivieri, pela amizade, apoio e companheirismo durante todo o Curso de Mestrado.

- A todos aqueles que, de alguma forma, contribuíram para a execução deste trabalho. 


\section{SUMÁRIO}

Página

LISTA DE FIGURAS ….........................................................

LISTA DE TABELAS .................................................................. vi

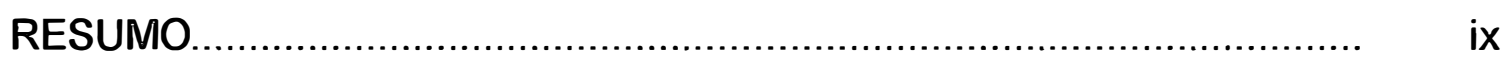

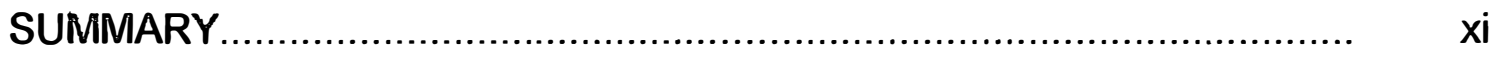

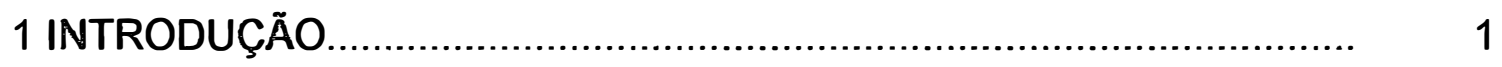

2 OBJETIVOS

3 REVISÃO DE LITERATURA ........................................................ 5

3.1 Considerações gerais................................................................... 5

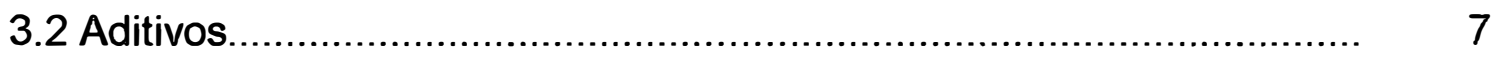

3.2.1 Ácido sórbico e seus derivados................................................... 11

3.3 Produtos dietéticos.............................................................. 13

3.3.1 Edulcorantes.................................................................... 15

3.4 Fatores que afetam a qualidade do morango................................... 21

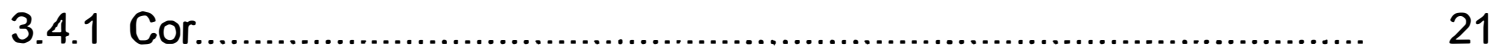

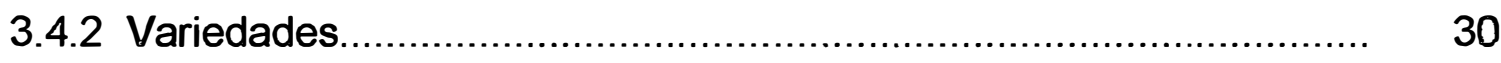

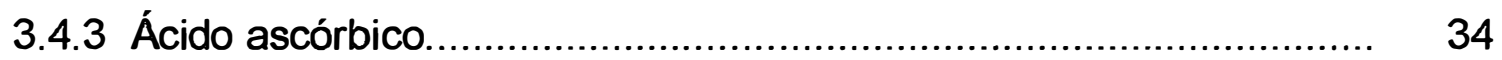

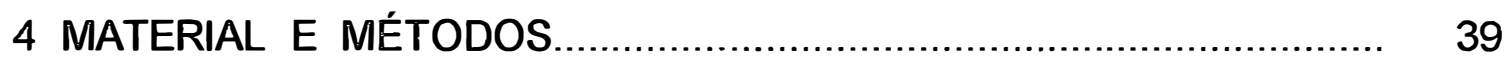

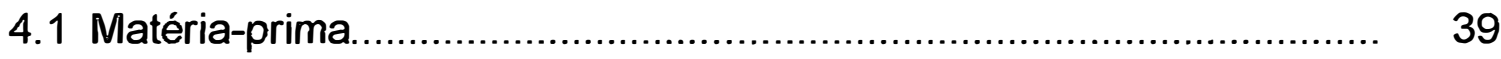


4.2 Caracterização da matéria-prima................................................... 40

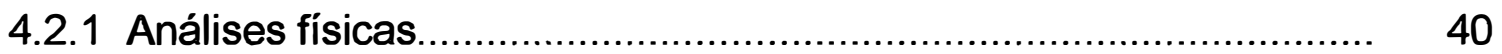

4.2.2 Análises químicas.................................................................. 41

4.3 Processamento dos morangos ........................................................ 43

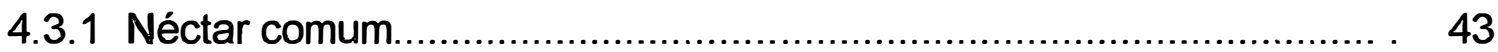

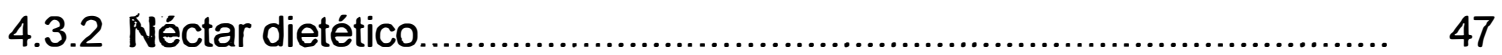

4.3.3 Acondicionamento............................................................... 52

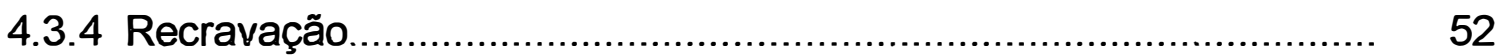

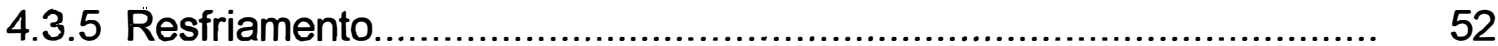

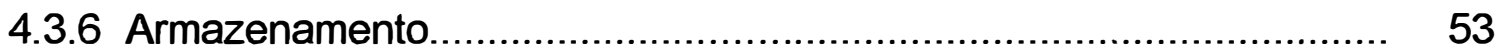

4.4 Avaliação dos néctares comum e dietético....................................... 53

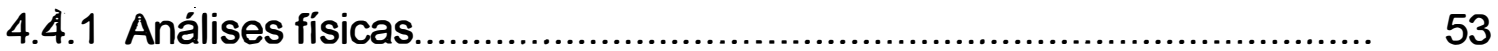

4.4.2 Análises químicas................................................................. 54

4.4.3 Análise sensorial.................................................................... 54

4.4.4 Análises estatísticas.............................................................. 57

5 RESULTADOS E DISCUSSÃO...................................................... 58

5.1 Caracterização da matéria-prima.................................................... 58

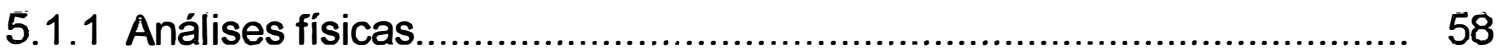

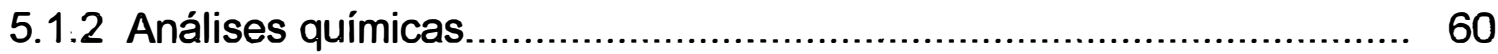

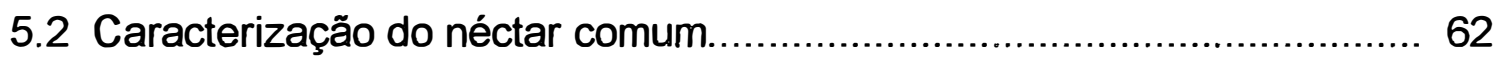

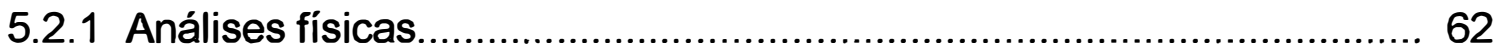




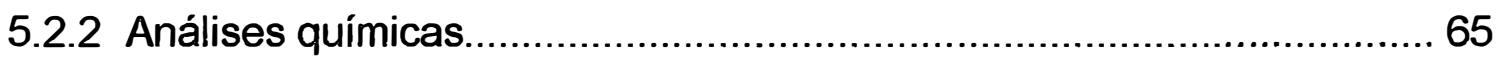

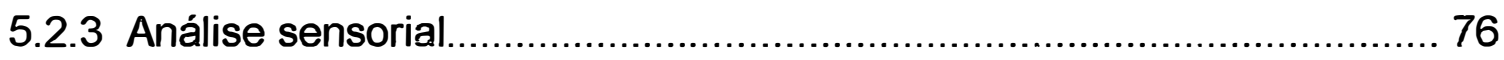

5.3 Caracterização do néctar dietético...................................................... 81

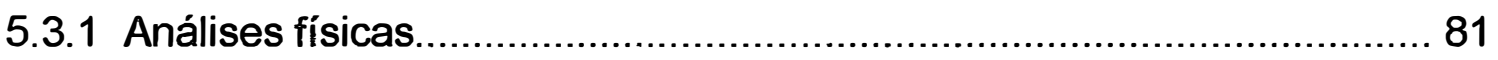

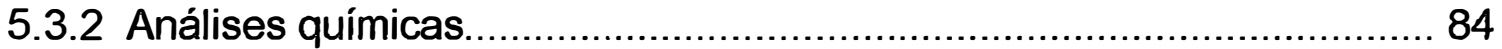

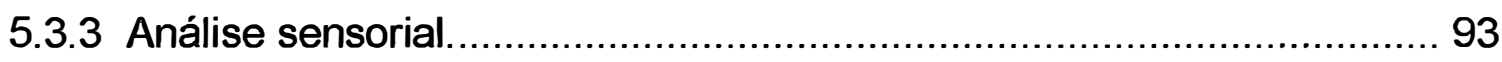

6 CONCLUSÕES

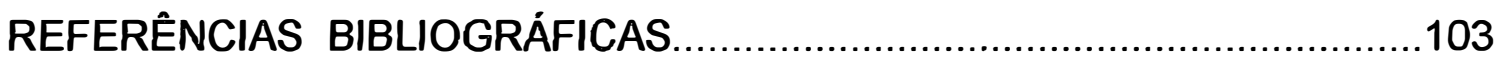




\section{LISTA DE FIGURAS}

Página

1. Fluxograma das operações utilizadas para obtenção do néctar comum.

2. Fluxograma dos tratamentos aos quais o purê de morango de cada variedade foi submetido para obtenção do néctar comum

3. Fluxograma das operações utilizadas para obtenção do néctar dietético.

4. Fluxograma dos tratamentos aos quais o purê de morango da variedade Oso Grande foi submetido .51 para obtenção do néctar dietético

5. Modelo de ficha utilizado na avaliação sensorial das amostras de néctar quanto à cor.

6. Modelo de ficha utilizado na avaliação sensorial das amostras de néctar quanto à consistência

7. Modelo de ficha utilizado na avaliação sensorial das amostras de néctar quanto ao sabor. 
8. Teores de ácido ascórbico dos néctares comuns de morango da variedade Guarani, em função do tempo de armazenamento

9. Teores de ácido ascórbico dos néctares comuns de morango da variedade Oso Grande, em função do tempo de armazenamento. 68

10. Teores de ácido ascórbico dos néctares comuns de morango, em função do tempo de armazenamento 68

11. Teores de acidez total titulável em néctares comuns de morango da variedade Guarani, em função do tempo de armazenamento. .70

12. Teores de acidez total titulável em néctares comuns de morango da variedade Oso Grande, em função do tempo de armazenamento.

13. Teores de acidez total titulável em néctares comuns de morango, em função do tempo de armazenamento. .71

14. Valores de $\mathrm{pH}$ dos néctares comuns de morango da variedade Guarani, em função do tempo de armazenamento. .73

15. Valores de $\mathrm{pH}$ dos néctares comuns de morango da variedade Oso Grande, em função do tempo de armazenamento 
16. Valores de $\mathrm{pH}$ dos néctares comuns de morango, em função do tempo de armazenamento.

17. Valores de sólidos solúveis totais dos néctares comuns de morango, em função do tempo de armazenamento. .76

18. Valores médios das notas obtidas na avaliação sensorial, quanto à cor dos néctares comuns de morango .78

19. Valores médios das notas obtidas na avaliação sensorial, quanto à consistência dos néctares comuns de morango.

20. Valores médios das notas obtidas na avaliação sensorial, quanto ao sabor dos néctares comuns de morango. .80

21. Valores médios das notas obtidas na avaliação sensorial, quanto aos atributos de qualidade dos néctares comuns.

22. Teores de ácido ascórbico dos néctares dietéticos de morango da variedade Guarani, em função do tempo de armazenamento 86

23. Teores de ácido ascórbico dos néctares dietéticos de morango da variedade Oso Grande, em função do tempo de armazenamento. 86

24. Teores de ácido ascórbico dos néctares dietéticos de morango, em função do tempo de armazenamento. 
25. Teores de acidez total titulável dos néctares dietéticos de morango da variedade Guarani, em função do tempo de armazenamento .89

26. Teores de acidez total titulável dos néctares dietéticos de morango da variedade Oso Grande, em função do tempo de armazenamento

27. Teores de acidez total titulável dos néctares dietéticos de morango, em função do tempo de armazenamento. .90

28. Valores de $\mathrm{pH}$ dos néctares dietéticos de morango da variedade Guarani, em função do tempo de armazenamento. 92

29. Valores de $\mathrm{pH}$ dos néctares dietéticos de morango da variedade Oso Grande, em função do tempo de armazenamento. .92

30. Valores de $\mathrm{pH}$ dos néctares dietéticos de morango, em função do tempo de armazenamento .93

31. Valores de sólidos solúveis totais dos néctares dietéticos de morango, em função do tempo de armazenamento. 94

32. Valores médios das notas obtidas na avaliação sensorial, quanto à cor dos néctares dietéticos de morango 
33. Valores médios das notas obtidas na avaliação sensorial, quanto à consistência dos néctares dietéticos de morango 98

34. Valores médios das notas obtidas na avaliação sensorial, quanto ao sabor dos néctares dietéticos de morango .99

35. Valores médios das notas obtidas na avaliação sensorial quanto aos atributos de qualidade dos néctares dietéticos de morango. 


\section{LISTA DE TABELAS}

Página

1. Características físicas dos morangos in natura (matéria-prima).

2. Características químicas dos morangos in natura (matéria-prima) 60

3. Valores médios de vácuo $(\mathrm{pol} . \mathrm{Hg}$ ) das latas dos néctares comuns de morango, em função do tempo de armazenamento.

4. Valores médios do peso bruto $(\mathrm{g})$ das latas dos néctares comuns de morango, em função do tempo de armazenamento.

5. Valores médios do peso líqüido ( $\mathrm{g}$ ) das latas dos néctares comuns de morango, em função do tempo de armazenamento. 65

6. Valores médios dos teores de ácido ascórbico $(\mathrm{mg} / 100 \mathrm{~g})$ dos néctares comuns de morango, em função do tempo de armazenamento. 66

7. Valores médios de acidez total titulável (g ácido cítrico/100g) dos néctares comuns de morango, em função do tempo de armazenamento. 
8. Valores médios de $\mathrm{pH}$ dos néctares comuns de morango, em função do tempo de armazenamento.

9. Valores médios de sólidos solúveis totais ( $\left.{ }^{\circ} \mathrm{Brix}\right)$ dos néctares comuns de morango, em função do tempo de armazenamento .75

10. Valores médios das análises sensoriais dos néctares comuns de morango, em função dos tratamentos.

11. Valores médios das análises sensoriais dos néctares comuns de morango, em função do tempo de armazenamento.

12. Valores médios de vácuo (pol. $\mathrm{Hg}$ ) das latas dos néctares dietéticos de morango, em função do tempo de armazenamento.

13. Valores médios do peso bruto ( $\mathrm{g}$ ) das latas dos néctares dietéticos de morango, em função do tempo de armazenamento.

14. Valores médios do peso líqüido $(\mathrm{g})$ das latas dos néctares dietéticos de morango, em função do tempo de armazenamento.

15. Valores médios dos teores de ácido ascórbico (mg/100g) dos néctares dietéticos de morango, em função do tempo de armazenamento.

16. Valores médios de acidez total titulável (g ácido cítrico/100g) dos néctares dietéticos de morango, em função do tempo de armazenamento. 
17. Valores médios de pH dos néctares dietéticos de morango, em função do tempo de armazenamento

18. Valores médios dos sólidos solúveis totais ( $\left.{ }^{\circ} \mathrm{Brix}\right)$ dos néctares dietéticos de morango, em função do tempo de armazenamento.

19. Valores médios das análises sensoriais dos néctares dietéticos de morango, em função dos tratamentos .96

20. Valores médios das análises sensoriais dos néctares dietéticos de morango, em função do tempo de armazenamento. .96 


\section{AVALIAÇÃO DA QUALIDADE DOS NÉCTARES COMUM E DIETÉTICO DE MORANGO DAS VARIEDADES GUARANI E OSO GRANDE}

Autora: Lúcia Cristina Costa Novaes Orientador: Prof. Dr. João Nunes Nogueira

\section{RESUMO}

Foram determinadas as características físico-químicas dos morangos das variedades Guarani e Oso Grande e com estes, elaborados néctares nas formas comum e dietética. Os néctares foram submetidos a diferentes tratamentos químicos (adição de sorbato de potássio, cloreto de estanho, ácido cítrico e ácido ascórbico), visando avaliar a qualidade destas variedades de morango para este tipo de processamento.

A qualidade da matéria-prima foi avaliada fisicamente em relação à textura, suculência e rendimento, e quimicamente em termos de $\mathrm{pH}$, sólidos soluveis totais, acidez total titulável e ácido ascórbico. As amostras dos néctares foram submetidas às análises físicas de vácuo, peso bruto e peso líqüido; análises químicas quanto aos teores de ácido ascórbico, acidez total titulável, 
$\mathrm{pH}$ e sólidos solúveis totais, e avaliadas sensorialmente quanto à cor, consistência e sabor.

Os resultados mostraram que a adição de ácido cítrico foi eficaz na preservação da coloração vermelha do néctar comum das duas variedades, bem como na cor, consistência e sabor do néctar dietético da variedade Oso Grande, sendo considerado o melhor tratamento. A variedade Guarani apresentou características mais apropriadas para a obtenção dos néctares comum e dietético, sendo superior à variedade Oso Grande quanto à cor, consistência e sabor. 


\section{QUALITY EVALUATION OF REGULAR AND LOW SUGAR STRAWBERRY NECTARS MADE FROM GUARANI AND OSO GRANDE VARIETIES}

Author: Lúcia Cristina Costa Novaes

Adviser: Prof. Dr. João Nunes Nogueira

\section{SUMMARY}

Physical and chemical characteristics were determined in Guarani and Oso Grande strawberry varieties. Regular and low sugar strawberry nectars were made from those varieties and submitted to different chemical treatments (addition of potassium sorbate, stannic chloride, citric acid and ascorbic acid), in order to evaluate both strawberry varieties'quality for nectars processing.

Quality of raw material was evaluated regarding to texture, succulency, yield, $\mathrm{pH}$, soluble solids, titratable acidity and ascorbic acid. Nectars'samples were submitted to physical determinations for vacuum, gross weight and net weight; chemical analysis for ascorbic acid, titratable acidity, $\mathrm{pH}$, 
and soluble solids, and organoleptic evaluation for color, consistency and flavour.

The results showed the efficiency of citric acid on keeping red color in regular nectar of both varieties, as well as color, consistency and flavour in low sugar nectar of Oso Grande variety, showing the additon of this component as the best treatment. Guarani was the most suitable variety for regular and low sugar nectars processing, being superior to Oso Grande, mainly regarding to color, consistency and flavour. 


\section{INTRODUÇÃO}

A planta do morangueiro é classificada pelos botânicos como pertencente à família das Rosaceas, enquadrando-se no gênero conhecido como Fragaria (Padovani, 1991).

No Brasil, a área cultivada de morango é de aproximadamente 613 ha, com uma estimativa de produção ao redor de 30 ton/ha no ano de 1996 (Instituto de Economia Agrícola, 1997). Dentre os Estados produtores, destacam-se São Paulo e Minas Gerais, onde se comercializam morangos principalmente in natura, e o Rio Grande do Sul, onde a maior parte da produção é industrializada (Passos, 1982 e Tessarioli Neto, 1993).

A produção nacional do morango é totalmente voltada para o mercado interno. Nos últimos anos, no entanto, tem havido exportação em pequena escala da fruta in natura ou industrializada para países como Argentina e Chile. O morangueiro, como cultura comercialmente importante, expandiu-se a partir da década de sessenta, após a obtenção de cultivares melhorados pelo Instituto Agronômico de Campinas (Padovani, 1991).

No Estado de São Paulo existem dois tipos de culturas de morango: uma, em que se produzem frutos e outra, em que se produzem mudas. Isso é feito para que haja uma especialização na produção de mudas e de frutos, de tal forma que a qualidade seja mantida em nível elevado. Normalmente, os 
locais reservados para a produção de mudas se situam isolados dos locais da produção de frutos visando-se, com isso, um melhor controle na sanidade de mudas produzidas. Dessa forma, todo ano o produtor adquire novas mudas que são utilizadas para a produção comercial de frutos (Tessarioli Neto,1993).

A partir de meados do século passado, com o desenvolvimento da ciência agronômica, as variedades foram ainda mais aperfeiçoadas, dando origem aos atuais cultivares. Atualmente o morango consiste numa atividade econômica de grande importância em diversos países da Europa, nos Estados Unidos, Japão e países da América Latina, dentre os quais o Brasil (Padovani, 1991).

Graças ao seu sabor atrativo e à sua boa produtividade, o morango se constitui, em escala mundial, em uma das mais importantes frutas pequenas (Padovani, 1991). Além disso, é uma fruta muito nutritiva, pois é fonte de vitamina $\mathrm{C}$, potássio e fibra dietética, além de apresentar baixas calorias. (Donald, 1994 e Souza, 1976). O seu cultivo, embora não muito fácil, pois exige cuidados constantes e um trabalho sistemático de preparo do solo, irrigação e combate de pragas e moléstias, chega a ser muito lucrativo, pois os preços alcançados no mercado são sempre crescentes (Padovani, 1991).

O desenvolvimento da variedade Guarani constituiu um verdadeiro marco para o mercado de morango industrializado no Estado de São Paulo. $O$ seu advento permitiu a auto-suficiência paulista no tocante ao morango para processamento, já que até o início dos anos oitenta, o morango congelado utilizado em São Paulo era importado do Rio Grande do Sul, com preços cada vez mais elevados devidos ao custo de transporte (Padovani, 1991). A variedade Oso Grande foi desenvolvida na Califórnia e está sendo cultivada no Brasil com bastante sucesso desde meados de 1994. 
Segundo a Legislação brasileira, pode-se definir néctar de fruta como sendo um produto não fermentado, não gaseificado, destinado ao consumo direto, obtido pela dissolução em água potável de parte comestivel da fruta (polpa e suco), adicionado de ácido e açúcares (Brasil, 1974). O néctar de morango é um produto de ótima aceitação, fácil processamento e pode ser elaborado sem maiores problemas nas agroindústrias de pequeno e médio portes. $\mathrm{O}$ aspecto mais importante a ser considerado é o da variedade, que deve ser adequada ao tipo de processamento.

O mercado dos produtos dietéticos vem consolidando-se como a grande tendência industrial da década, pois estes já fazem parte dos hábitos alimentares da sociedade moderna (Rodrigues, 1995). A partir dos anos 60 começaram a surgir os primeiros indícios de alternativas ao consumo do açúcar, visando inicialmente os diabéticos, obesos e hipertensos. Anos depois, preocupações com a forma física e com hábito de vida mais saudável, colocaram em evidência o uso dos adoçantes, que se consolidaram definitivamente na década de 80 e cujo mercado cresceu de maneira significativa (Stringuetto, 1991).

Segundo Fonseca \& Nogueira (1989), a procura e aceitação de qualquer produto depende diretamente de sua qualidade. Daí a importância de se empregar no processamento, além de uma matéria-prima de boa qualidade, técnicas que permitam a máxima preservação das características do produto in natura.

Desta forma, utilizando-se variedades selecionadas e desenvolvendo uma tecnologia adequada para a obtenção de um novo produto, será possivel oferecer tanto ao mercado interno como ao externo um produto de alta qualidade, beneficiando diretamente as indústrias, produtores e consumidores. 


\section{2 - OBJETIVOS}

O presente trabalho tem por objetivos, elaborar e avaliar a qualidade dos néctares comum e dietético das variedades de morango Guarani e Oso Grande. Através do emprego de tecnologia de baixo investimento e, visando-se um maior aproveitamento da produção, pretende-se obter um produto de alta qualidade, atendendo assim as exigências dos consumidores. 


\section{3 - REVISÃO DE LITERATURA}

\subsection{Considerações Gerais}

O morango (Fragaria $s p$ ) é um fruto bastante perecivel, de maturação desuniforme e período de produção relativamente curto (Goldoni et al., 1981), devendo, portanto, ser processado o mais rapidamente possivel após a colheita. Para a industrialização é necessário adaptar e selecionar variedades, empregar, quando necessário, armazenamento refrigerado, bem como técnicas de processamento satisfatórias, a fim de que se possa oferecer ao mercado consumidor um produto tal que satisfaça a sua exigência, que se torna cada vez maior com o passar dos anos (Fonseca \& Nogueira, 1989).

Segundo Gava (1978), a industrialização dos produtos agropecuários pode contribuir consideravelmente para a melhoria da dieta de um pais e do estado nutricional dos seus habitantes. A amplitude dessa contribuição depende de diversos fatores, como a existência de uma agricultura desenvolvida que possa receber uma tecnologia avançada, bem como o nível e poder aquisitivo da população.

Os morangos processados podem ser usados em uma ampla escala de produtos, incluindo os biscoitos, bolos, sucos de frutas e outras bebidas, 
bem como iogurtes, geléias e marmeladas (Donald, 1994 e Goldoni et. al., 1981).

Suco de fruta, segundo a Legislação brasileira (Brasil, 1974), é todo o produto obtido por extração de frutas maduras por processos tecnológicos adequados. Este suco, que leva o nome da fruta que the deu origem, pode ser classificado quanto à concentração ou quanto à forma de preservação.

O suco diluído com água e/ou xarope (de sacarose, de glicose, etc.) não pode ser oficialmente denominado suco, mas sim, deve ser chamado de "néctar", "coquetel", "bebida" ou "juice drink", dependendo da porcentagem de fruta que entra em sua formulação. No néctar, os ingredientes de frutas .podem ser o purê, o suco simples ou concentrado e os ingredientes opcionais, que são: suco de limão, ácidos cítrico, maleico ou fumárico como acidificantes, ácido ascórbico como antioxidante, e outros (Alves \& Garcia, 1993).

Os néctares de frutas tropicais, simples ou misturados, são produtos de larga aceitação em muitos países. Os néctares de goiaba, mamão e manga constituem, inclusive, produtos de exportação nos EUA, Havaí e Índia. A maior parte da produção desses manufaturados porém, destina-se ao mercado interno. No Brasil, o néctar começou a se firmar como um produto de boa aceitação no mercado interno, devido não somente ao hábito que o brasileiro está adquirindo em relação ao consumo de produtos líqüidos de frutas (néctares e sucos), como também à melhoria do poder aquisitivo de certas faixas da população (Salomón et al., 1977).

O Brasil atende aos requisitos para conquistar os consumidores de sucos e néctares, que são: ótima qualidade, sabores agradáveis, aroma, boa aparência de produtos, higiene, além de possuir todas as condições 
necessárias para se fixar como um grande produtor a nível mundial (Dayrell et al., 1982; Menezes, 1988 e Sucos..., 1989).

A conservação de sucos e néctares de frutas é basicamente determinada pelas condições que preservam as suas qualidades organolépticas (aroma, cor, sabor, consistência, etc.) e que previnem o desenvolvimento de microrganismos deteriorantes e a ocorrência de reações químicas ou enzímicas indesejáveis (Uboldi Eiroa, 1989).

Kwasniewska et al. (1985) analisaram e compararam as propriedades físico-químicas e sensoriais de sucos e néctares de morangos, maçãs e amoras. A maior variabilidade nas propriedades foi observada em produtos de amora, os quais são mais sensíveis às condições de armazenamento.

Segundo Chitarra \& Chitarra (1990), o controle de qualidade de frutas, tanto dos produtos destinados ao consumo direto, como daqueles para 0 processamento, tem como objetivo a obtenção de produtos com qualidade padronizada e constante, visando, principalmente, as vantagens econômicas básicas (minimização de custos e maximização de rendimento pela prevenção de defeitos), observando-se também os critérios de segurança de uso desses produtos. Para tal, o controle deve abranger todo o ciclo de produção, incluindo o produto, o material de embalagem, condições de armazenamento e/ou processamento e comercialização.

\subsection{Aditivos}

A presença de um produto no mercado depende, basicamente, da sua aprovação junto ao consumidor. Para isso, são feitos estudos prévios que 
determinam a plasticidade, aroma, cor, sabor, qualidade nutricional, etc. Todos esses ítens são de extrema importância para a pesquisa e desenvolvimento do produto correto para o seu público alvo (Matérias-primas..., 1994).

No Brasil, o Ministério da Saúde, através da Comissão Nacional de Normas e Padrões para Alimentos (CNNPA), define um aditivo como a "substância ou mistura de substâncias, dotada ou não de valor nutritivo, adicionada ao alimento com a finalidade de impedir alterações, manter, conferir e/ou intensificar seu aroma, cor e sabor, modificar ou manter seu estado físico geral ou exercer qualquer ação exigida para uma boa tecnologia de fabricação do alimento" (Volpi, 1985). Além das substâncias e elementos químicos presentes de modo natural nas matérias-primas alimentícias, outros produtos poderão ser incorporados às mesmas, direta ou indiretamente, durante o processamento, acondicionamento e transporte dos alimentos. Esses aditivos compreendem, entre outros, agentes inibidores de crescimento microbiano, antioxidante, acidulantes, aromatizantes, corantes, estabilizantes e emulsificantes, e geralmente são codificados nos rótulos dos alimentos (Pavanello, 1990).

De acordo com Toledo (1986), o advento do uso de aditivos em alimentos no começo deste século, trouxe à sociedade benefícios inegáveis, traduzidos principalmente no aumento de produção e disponibilidade de alimentos, na melhoria de suas propriedades funcionais e sensoriais, bem como numa diminuição de custos. Porém, o seu emprego em alimentos somente é permitido após a consideração de diversos fatores que incluem a necessidade tecnológica do aditivo e, principalmente, o estabelecimento de sua segurança. 
A utilização de aditivos, como os conservantes, ainda é um tabu, sobretudo pela falta de conhecimento a respeito da ação desses elementos. Em paises mais desenvolvidos, onde as informações são, geralmente, passadas com maior clareza para o consumidor, o emprego de conservantes e aditivos, em geral é um assunto que quase já não merece comentários. Mas, são justamente os conservantes que permitem aumentar a vida útil ("shelf-life") dos produtos para que possam suportar, sem alterações em suas propriedades, longos períodos de transporte e de estocagem nos pontos de venda e nas próprias residências dos consumidores (Sucos...,1989).

Gava (1987) afirma que, por várias razões, generalizou-se na mente da população leiga, e até na de muitos profissionais da área de alimentos, a idéia da quimiofobia, aceitando-se que aquilo que é químico é ruim, e o que é natural, é bom. É uma generalização sem fundamento científico, pois todo material do universo é de natureza química, não somente os aditivos, mas todos os alimentos, o nosso corpo humano e todo o ambiente. É preciso analisar cada substância química individualmente, quer seja de origem natural ou sintética.

De acordo com Nazário (1988), desde que se respeitem os limites estabelecidos pela legislação, todos os aditivos alimentícios, sem exceção, são inofensivos à saúde. Da mesma forma, é importante frisar que qualquer substância que compõe uma dieta alimentar, seja de origem natural ou não, poderá provocar prejuízos à saúde se ingerida em quantidades excessivas. Assim, conclui-se que tudo o que consumimos em excesso pode ser tóxico ou provocar danos ao organismo, mesmo em se tratando de produtos de consumo diário, com os quais já estamos habituados. 
Sem os aditivos seria praticamente impossivel a evolução da indústria de alimentos, e hoje não teríamos a diversificação de produtos alimentícos que estão disponiveis no mercado (Pavanello, 1990). A necessidade de seu uso, porém, vem sendo ampliada com o desenvolvimento tecnológico, que faz as indústrias sofisticarem seus produtos para atender um mercado cada vez mais pressionado pela concentração crescente das populações e por alterações constantes nos hábitos de vida (Nazário, 1988).

Segundo Alves \& Garcia (1993) e Uboldi Eiroa (1989), a conservação dos sucos e néctares de frutas é determinada, primeiramente, pela prevenção do desenvolvimento de microrganismos deteriorantes e pela inibição da ação de enzimas naturais, o que é obtido por meio do tratamento térmico a que é submetido o produto e/ou pelo uso de conservantes químicos ou comercialização sob refrigeração / congelação.

As temperaturas de 85 a $90^{\circ} \mathrm{C}$ normalmente empregadas no tratamento térmico para a preservação de sucos podem não ser suficientes para inativar fungos termoresistentes. O uso de temperaturas mais elevadas afeta as características físico-químicas dos sucos e, portanto, o controle da deterioração por esses microrganismos repousa fundamentalmente na adoção de práticas higiênico-sanitárias adequadas, visando diminuir a possibilidade de contaminação das matérias-primas. Também é possível controlar esses tipos de fungos com o uso de conservantes químicos, mesmo em produtos pasteurizados (Alves \& Garcia, 1991).

Dentre as classes funcionais de aditivos alimentares utilizados em bebidas, duas se destacam particularmente, que são os acidulantes e os conservantes. Para que seja aprovado um conservante químico a ser utilizado 
em alimentos para consumo humano, inúmeros estudos são realizados por especialistas da Organização Mundial da Saúde (Almeida, 1996b).

De acordo com Leitão et al. (1977), o uso de conservantes é bastante comum em nossas condições, destacando-se o ácido benzóico ou seus sais de sódio e potássio, o ácido sórbico ou sorbatos e compostos de enxofre. A concentração máxima desses conservantes é controlada pela Legislação, sendo importante destacar que a eficiência do tratamento depende de inúmeros fatores, principalmente concentração, temperatura do alimento, tipo e grau de contaminação presente e pH do produto.

A Legislação brasileira que regulamenta o uso de aditivos em alimentos, permite o emprego do ácido benzóico e seus sais como conservadores em néctares e sucos de frutas, no teor máximo de 0,1\% (Brasil, 1988a).

\section{2. Ácido sórbico e seus derivados}

O ácido sórbico é o único ácido orgânico insaturado produzido sinteticamente, permitido como conservante em alimentos. Em face de sua característica neutra no sabor, é recomendável para uso em sucos e bebidas, em contraste com os benzoatos, os quais alteram o sabor. São eficientes no controle de fungos e leveduras e pouco eficientes no controle de bactérias. $\dot{E}$ ligeiramente solúvel em água $\left(0,16 \mathrm{~g} / 100 \mathrm{ml} \mathrm{H}_{2} \mathrm{O}\right)$ e o sal de potássio é bastante solúvel $\left(139 \mathrm{~g} / 100 \mathrm{ml} \mathrm{H}_{2} \mathrm{O}\right.$ a $\left.20^{\circ} \mathrm{C}\right)$. $\mathrm{O} \mathrm{pH}$ ótimo de atuação estende-se até $6,0 . \mathrm{A}$ adição do sorbato de potássio em produtos processados deve ser feita após o tratamento térmico, evitando-se perdas. (Araújo, 1990). 
O código de rotulagem para os conservantes no Brasil é P.IV. O código internacional do sorbato de potássio é E202 e seu peso molecular é 150,22 ,sendo este o mais solúvel dos sais (Almeida, 1996b).

Von Schelhorn (1953) explica que a ação dos conservantes é resultante de reação com a membrana da célula microbiana, aumentando a sua permeabilidade. A célula passa a admitir toxinas e também há a possibilidade do suco celular se extravasar. Outra possibilidade é a do produto destruir ou inativar enzimas celulares. Entretanto, segundo Goldoni et al.(1981), a hipótese mais interessante é a que se relaciona com o pH do meio. Estudos feitos, relacionando-se o efeito conjunto de substâncias anti-microbianas aliadas a pH baixo, concluíram que estes compostos eram efetivos, desde que o $\mathrm{pH}$ fosse mantido abaixo de 7. Se o pH estiver entre 6 e 5,1, o seu efeito é mínimo, e só é realmente efetivo entre os valores de 4,8 e 3,1.

De acordo com Goldoni et al. (1981), a principal deterioração que ocorre com sucos armazenados é a fermentação por leveduras. As leis brasileiras permitem o uso do ácido sórbico e seus sais em sucos de frutas na concentração máxima de $0,1 \%$, sendo suficiente para inibir leveduras e fungos filamentosos em produtos alimentícios, além de algumas bactérias catalase positiva, como: Salmonella spp, Streptococcus faecalis e Staphylococcus aureus. Leitão et al. (1977) afirmam que as frutas e seus produtos derivados (sucos, refrescos, néctares, refrigerantes e xaropes) normalmente apresentam valores de pH abaixo de 4,0, razão pela qual as bactérias patogênicas não se desenvolvem nem sobrevivem por muito tempo em tais níveis de $\mathrm{pH}$.

Salunkhe (1955) estudou a eficiência da ação conservadora do ácido sórbico em suco pasteurizado de maçã e observou o aumento da vida útil do produto, sem prejudicar as características organolépticas do mesmo. Beneke \& 
Fabian (1955) também utilizaram o ácido sórbico em purê de morangos, e este conseguiu inibir o desenvolvimento de fungos do gênero Botrytis e Rhizopus. Com relação aos tratamentos que envolveram o emprego de conservantes ou não, Goldoni et al. (1981) observaram que aquele com a adição mostrou ser mais eficiente na retenção do ácido ascórbico.

\subsection{Produtos Dietéticos}

De acordo com Stringuetto (1991), a década de 80 foi talvez a que mais questionou os benefícios e malefícios dos alimentos, fazendo com que os pesquisadores se empenhassem nas descobertas promovidas pelos avanços tecnológicos na área. Esse avanço é responsável por uma infinidade de produtos lançados no mercado e, aos cientistas cabe explorar os reais valores de cada elemento do cardápio.

Os chamados produtos dietéticos têm revolucionado o mercado alimentício e conquistado consumidores diabéticos, obesos, pessoas com distúrbios orgânicos e um grande número de pessoas saudáveis, preocupadas com a saúde e a boa forma física. Esse crescimento explosivo aconteceu a partir de 1988, com as modificações na Legislação brasileira que passou a considerar os dietéticos como alimento e não mais como remédio, como eram então chamados. Segundo dados da ABIAD (Associação Brasileira da Indústria de Alimentos Dietéticos), o público consumidor, atualmente, chega à casa dos 30 milhões de pessoas, sendo cerca de 10 milhões o número de produtos dietéticos existentes no país (Arêas, 1991 e Menezes \& Viegas, 1990).

O otimismo dos fabricantes de produtos dietéticos tem fundamento na própria tendência de consumo deste segmento (que engloba adoçantes, doces, 
geléias, massas e pós para pudins e gelatina) que vem registrando um aumento médio anual de $30 \%$ nos últimos cinco anos. Até então, "produto dietético" era sinônimo de edulcorante, que forma a linha mais significativa deste mercado, e era consumido por um público restrito, basicamente os diabéticos, sob recomendação médica. No entanto, a crescente preocupação da população com saúde e estética foi alterando esta situação. Os produtos dietéticos passaram a ser procurados também por atletas ou pessoas interessadas simplesmente em manter a forma física (Freitas, 1988).

Pela portaria que rege as leis da alimentação, consideram-se "alimentos dietéticos" ou "de regime" ou "alimentos para dietas especiais", os alimentos e as bebidas especialmente elaborados e formulados, quer pela escolha adequada de seus ingredientes, quer pela substituição, adição ou supressão parcial ou total de um ou mais de seus componentes, de forma que sua composição atenda às necessidades dietéticas específicas de pessoas com exigências metabólicas, fisiológicas ou físicas, particulares (Costa, 1995).

Pela Legislação brasileira em vigor, os produtos diet são aqueles que possuem redução total de alguns componentes como, açúcar, gordura, colesterol, sódio, aminoácidos e proteínas, especialmente formulados para atender pessoas que tenham disfunção ou distúrbio físico ou metabólico, como os diabéticos e hipertensos. Já os produtos light são aqueles que devem ter $25 \%$ a menos de seu componente mais calórico, seja açúcar, gordura, carboidrato, etc. Porém, mesmo sendo diet ou light, o alimento pode ser altamente calórico (Amoedo, 1997).

De acordo com Rodrigues (1995), várias pessoas ainda acreditam que os produtos diet são apenas indicados para os diabéticos, o que é uma desinformação. Os biscoitos sem glúten, por exemplo, são diet e destinados 
principalmente a portadores de intolerância à ingestão de glúten. $\mathrm{O}$ sal diet, outro exemplo, é uma mistura de sais à base de cloreto de potássio. Como o potássio não causa aumento na pressão arterial, este produto tem como público alvo os hipertensos, mas também pode ser consumido por todas as pessoas.

Belo (1995) e Costa (1995) ressaltam que os produtos dietéticos também não devem ser consumidos à vontade pelos diabéticos, pois os doces, certas bebidas e outros produtos à base de frutas, contêm os carboidratos naturais da própria fruta.

De acordo com Abreu (1995), todos os produtos devem levar em suas embalagens a quantidade de cada componente em $100 \mathrm{~g}$ do produto. Quando a substituição de um componente por outro não significar a diminuição do valor calórico, é obrigatório constar no rótulo a informação: "este produto não é reduzido de calorias". Também deve constar na embalagem as inscrições: "alimentos para fins especiais" ou "alimentos dietéticos", caso sejam estas as destinações do produto.

\subsubsection{Edulcorantes}

Edulcorantes são aditivos alimentares, definidos como substâncias orgânicas não glicídicas, capazes de conferir gosto doce aos alimentos (Brasil, 1988a).

O emprego de edulcorantes na indústria de alimentos encontra justificativa nos produtos destinados a consumidores que necessitam de restrição calórica em suas dietas, bem como para aqueles portadores de 
diabetes, além de ajudar a diminuir a incidência de cárie dental e substituir o açúcar quando este não estiver disponível no mercado (Muradian \& Penteado, 1990).

Segundo Almeida (1996a), o avanço científico e tecnológico sobre edulcorantes, sua aplicação em muitos alimentos, liberação para uso em bebidas, tanto por parte dos países menos desenvolvidos como pelas grandes potências, somados à preocupação das pessoas com a estética e, principalmente, uma representativa parcela da sociedade brasileira que, por ordem médica, tem que ter rigoroso controle de açúcar, como os obesos e os diabéticos, proporcionaram uma Legislação específica para bebidas dietéticas.

Assim sendo, as bebidas dietéticas são definidas como "bebidas não alcoólicas, destinadas a complementar dietas especiais, apresentando características semelhantes às bebidas convencionais, onde o açúcar seja substituido integralmente por edulcorantes". Os edulcorantes permitidos podem ser calóricos ou não calóricos, artificiais ou naturais. Na rotulagem das bebidas dietéticas aprovadas na portaria, além das informações exigidas, deve constar a expressão "contém fenilalanina", quando na bebida contiver o aspartame como edulcorante (Almeida, 1996a).

De acordo com Stringuetto (1991), o ser humano tem a capacidade de sentir quatro tipos de gostos: o doce, o salgado, o amargo e o ácido. No entanto, o gosto adocicado é o que mais the agrada e, desde sua descoberta, o açúcar tornou-se indispensável no mundo ocidental.

Eliminar gorduras e açúcares dos alimentos não é o maior desafio dos pesquisadores da área de alimentos. A tarefa mais difícil é reduzir a quantidade de tais ingredientes sem alterar o sabor e a textura dos produtos, 
eliminando o desagradável gosto residual, conhecido por "after taste". Este surge quando são captados gostos muito distintos em um mesmo alimento, sendo um problema na maioria dos produtos diet e light. Os componentes de alguns substitutos do açúcar são formados por moléculas que deixam um gosto doce quando detectados pela ponta da língua. Mas, ao entrar em contato com a base do órgão, produzem aquele gosto amargo que prejudica a aceitação do produto. (Amoedo, 1997).

De acordo com a Legislação brasileira (Brasil,1988a), os edulcorantes permitidos podem ser calóricos ou não calóricos e artificiais (sacarina, ciclamato, acessulfame $\mathrm{K}$ e aspartame) ou naturais (esteviosídeo, sorbitol e manitol).

Dentre os edulcorantes naturais, o esteviosídeo è um glicosídeo extraído das folhas da Stevia rebaudiana (Bert.), planta nativa do Paraguai e do Brasil. Embora conhecida há séculos pelos índios guarani, o nome científico da planta é uma homenagem ao naturalista Moisés S. Bertoni, que a descobriu em 1889 e do químico Ovídio Rebaudi, um dos primeiros a estudar suas características químicas.

Este edulcorante é cerca de $\mathbf{3 0 0}$ vezes mais doce do que a sacarose e apresenta efeito sinérgico com a sacarina, ciclamato, aspartame, sorbitol e manitol (Almeida, 1996a e Kinghorn \& Soerjato, 1986). Por não ser metabolizável nem calórico, é quase totalmente absorvido pelo trato gastrointestinal alto e eliminado sem alteração pela urina. Os trabalhos de avaliação toxicológica estabeleceram um IDA (Ingestão diária aceitável) de 5,5 $\mathrm{mg} / \mathrm{kg}$ de peso corpóreo (Almeida, 1996a). Além disso, o esteviosídeo é altamente estável em meio ácido e ao aquecimento (Muradian \& Penteado, 1990). 
Segundo Sakaguchi \& Kan (1982), todos os glicosídeos da Stevia rebaudiana apresentam características doces, mas existe uma grande variação quanto à intensidade e qualidade. Destes, os que alcançam maior importância são o esteviosídeo e o rebaudeosídeo A. A intensidade de doçura dos adoçantes da Stevia rebaudiana é semelhante à da sacarose, e o seu gosto residual tem permanência mais evidente e prolongada do que o da sacarose (Randi \& Felipe, 1980).

Os diversos tipos de edulcorantes apresentam características diferentes que podem beneficiar um produto quando combinados (Menezes \& Viegas, 1990) e a mistura entre eles, para a produção de vários produtos, principalmente os líqüidos, se dá devido às propriedades superiores que cada um possui (Stringuetto, 1991).

Ishima \& Katayama', citados por Sakaguchi \& Kan (1982), experimentaram misturar diversos açúcares com esteviosídeo, observando a qualidade e o gosto residual. Após analisarem os dados estatisticamente, concluíram que, para o aperfeiçoamento do gosto doce, o melhor é acrescentar ao esteviosídeo a sacarose, seguindo-se a glicose, frutose, sorbitol e manitol; a que deixa menor gosto residual é a mistura com a frutose. Também existem relatos que revelam que os ácidos cítrico, acético, lático, málico e tartárico diminuem o gosto residual do esteviosídeo.

Abou-Zaid et al. (1991) estudaram várias misturas de edulcorantes na produção de néctar de apricot destinado aos diabéticos. $O$ néctar foi preparado com polpa da fruta e misturas de edulcorantes como, frutose, sorbitol, aspartame e acessulfame $\mathrm{K}$. Os resultados mostraram que a mistura com $50 \%$

1 ISHIMA, N.; KATAYAMA, O. Sensory evaluation of stevioside as a sweetener. Rep. Nat.

Food Resp. Inst., v.3, p.80-85, 1976. 
de frutose e $50 \%$ de acessulfame $\mathrm{K}$ apresentou um néctar com características organolépticas mais adequadas.

El-Zoghbi \& Siliha (1992) estudaram o efeito de misturas de edulcorantes sobre as propriedades químicas e físicas em néctar de apricot. Os néctares ( $3 \%$ de frutose ou $4 \%$ de xilitol $+0,030 \%$ a $0,042 \%$ de acessulfame $K$ ou aspartame) foram analisados durante 6 meses em relação às suas propriedades químicas, físicas e organolépticas. Os resultados mostraram que os sólidos solúveis totais diminuíram acentuadamente com a adição de edulcorantes. A acidez total não alterou, enquanto que o teor de ácido ascórbico diminuiu em cerca de $70-80 \%$, dependendo do tipo de edulcorante utilizado. Comparando-se com o tratamento testemunha (13\% de sacarose), observou-se que a viscosidade aumentou, enquanto que a coloração foi perdida. As avaliações organolépticas mostraram que as combinações de edulcorantes (frutose+aspartame ou xilitol+aspartame) foram altamente aceitáveis.

Pastor et al. (1996) analisaram dezesseis amostras de néctares dietéticos e as compararam com amostras de néctares comuns. Estes autores não observaram diferenças sensoriais quanto ao sabor entre os diferentes tipos de néctares.

Aguiar et al. (1987), após a análise de vários trabalhos, consideraram que o esteviosídeo apresentava uma boa margem de segurança à saúde humana para ser usado como edulcorante em alimentos e bebidas. Rocco et al. (1991) estudaram a preferência entre adoçantes comerciais e concluíram que o preferido foi a sacarose, seguido de ciclamato/sacarina, aspartame, ficando o esteviosídeo em quarto lugar. 
O edulcorante natural sorbitol pertence à categoria dos álcoois poliídricos ou polióis e é obtido pela redução da glicose com catalizador metálico de hidrogênio (Almeida, 1996a; Emodi, 1982 e Muradian \& Penteado, 1991). É o poliol mais encontrado na natureza (maçã, pêra, pêssego, ameixa, etc.) e o seu poder adoçante é cerca de $50 \%$ o da sacarose. É mais lentamente absorvido pelo intestino delgado que a sacarose, mas a porção absorvida é efetivamente metabolizada no fígado, independentemente da insulina. Apesar de ser utilizado como precursor da glicose pelo fígado e o subseqüente metabolismo da glicose requerer insulina, a concentração de glicose no sangue aumenta muito pouco.

A característica principal deste edulcorante é de dar "corpo" à bebida (Aguiar et al., 1987 e Almeida, 1996a). Além de sua aplicação em dietas alimentares especiais, o sorbitol também é utilizado como umectante, estabilizante e seqüestrante de alguns metais multivalentes (Dwivedi, 1986).

Uma propriedade útil do sorbitol é que, embora contenha o mesmo número de calorias da sacarose (4cal/g), é absorvido mais lentamente no trato gastrodigestivo. Outra vantagem do uso do sorbitol é o seu potencial cariogênico relativamente baixo. Estudos realizados demonstraram uma redução de $30 \%$ nas cáries dentais, em ratos que consumiram dieta contendo sorbitol (Muradian \& Penteado, 1990).

De acordo com Soler (1991), o edulcorante sorbitol, embora não substituia totalmente os açúcares, apresenta-se como substituto alternativo em algumas variedades de produtos, especialmente nos regimes com restrições de açúcares. O poder adoçante do sorbitol é de aproximadamente $60 \%$ em relação ao da sacarose. Este edulcorante é utilizado em alimentos, de acordo com regulamentos e normas para o produto. É estável sobre uma larga faixa de 
pH e não sofre modificações quando submetido às temperaturas usuais nos processos de produção de alimentos.

Dwivedi (1986) observou que, três doses diárias de sorbitol adicionado às dietas de crianças diabéticas, durante as refeições, foram toleradas sem que estas apresentassem diarréia e também sem necessidade de aumentar a taxa de insulina.

Gava (1987) afirma que, à medida que a humanidade aumenta seus conhecimentos sobre gosto, segurança, tecnologia e, à medida que novos edulcorantes são aprovados, o conceito do uso combinado de edulcorantes é o que se aproxima do edulcorante não calórico ideal, que nos proverá de infindáveis possibilidades de emprego em produtos alimentícios.

\section{4 - Fatores que afetam a qualidade do morango}

\subsection{1 - Cor}

A percepção do mundo ao nosso redor é dada pelos nossos sentidos. Destes, o impacto visual é o mais marcante, não sendo definido apenas pela forma e aspecto dos objetos, mas também pela cor. Dos três principais atributos de qualidade dos alimentos, a cor torna-se cada vez mais importante, à medida que os alimentos são expostos e vendidos, como por exemplo, em supermercados (Ferreira, 1991).

Quando se escolhe, se seleciona ou simplesmente se observa um objeto qualquer, o impacto visual causado pela cor geralmente se sobrepõe ao causado pelos outros atributos, e isto ocorre porque as cores caracterizam 
sobremaneira os objetos, constituindo-se no primeiro critério para sua aplicação ou rejeição (Clydesdale, 1993 e Ferreira, 1991).

A cor é um fator importante para avaliar a qualidade de um alimento. De fato, freqüentemente está ligado à maturação, presença ou não de impurezas, realização apropriada ou defeituosa de um tratamento tecnológico, condições de armazenamento, começo de deterioração por microrganismos, etc. Por isso é que se baseiam na cor vários métodos oficiais para avaliar a qualidade dos alimentos (Cheftel et al., 1987).

Clydesdale (1993) mostrou que a cor afeta a percepção de outras características sensoriais, como sabor e aroma, afetando direta ou indiretamente a aceitabilidade e a preferência de alimentos e bebidas. De acordo com Salomón et al. (1977), as condições de armazenamento do néctar, qualquer que seja a sua formulação, influenciam as características da cor do produto, notando-se um escurecimento quando ele é deixado por períodos prolongados à temperatura ambiente.

A maioria dos frutos e hortaliças de cor vermelha a púrpura ou violeta, é rica em antocianinas. A variação da cor entre cultivares da mesma espécie é usualmente devida a diferenças nas quantidades desses pigmentos. Estes, encontram-se não somente nos vacúolos celulares, como também nas camadas superficiais da epiderme. Como são de cor forte, em geral ocultam a clorofila e os carotenóides e são muito aprecidados nos produtos destinados ao consumo in natura, bem como em produtos processados (Chitarra \& Chitarra, 1990).

Segundo Abers \& Wrolstad (1979), Little (1977) e Rwabahizi \& Wrolstad (1988), a deterioração relativamente rápida da cor atrativa de 
conservas de morangos frescos, tem sido um problema persistente que vem preocupando os pesquisadores da área de alimentos por vários anos.

Bakker et al. (1992) e Bakker \& Bridle (1992) afirmam que a principal antocianina responsável pela coloração em morangos é a pelargonidina 3 glucosídeo, estando também presente a cianidina 3 - glucosídeo. A establilidade da cor em vários produtos (morango como geléias, sucos e purês) é o principal problema. O escurecimento, provocado pela degradação de ácido ascórbico e polimerização de antocianinas com outros compostos fenólicos, também contribui para a perda da coloração vermelha, aumentando a taxa de escurecimento em suco de morango.

De acordo com Cash \& Sistrunk (1970), a cor em morangos é um importante aspecto de controle de qualidade durante o processamento e armazenamento, devido ao complexo natural de pigmentos antociânicos e de diferentes tipos de reações que acontecem em seus produtos, mesmo após a congelação ou outros tipos de processamento. Estes autores estudaram o efeito de algumas substâncias químicas na coloração do purê de morango e observaram que a descoloração de pigmentos antociânicos foi acelerada pela presença de ácido ascórbico, ácido dehidroascórbico e açúcares.

A interação do ácido ascórbico com as antocianinas e subseqüente degradação destes compostos, é um importante problema já que, muitos produtos de frutas possuem elevado teor de ácido ascórbico. A presença do oxigênio, que favorece a oxidação desta vitamina, é uma das condições responsáveis pela máxima perda de antocianina em sucos de morango, já que quando o oxigênio é excluído, não se observaram mudanças acentuadas de coloração. Estes autores concluíram, através de vários trabalhos em produtos de morango, que o ácido ascórbico acelerou a perda de 
antocianinas tanto em amostras armazenadas na presença de nitrogênio como também do oxigênio, sendo esta mais acelerada sob condições aeróbicas (Bakker et al., 1992).

O exato mecanismo de degradação das antocianinas em sistemas aquosos simples ainda não está bem explicado. Segundo Markakis (1982), o $\mathrm{pH}$ exerce profunda influência sobre a estabilidade da cor das antocianinas, sendo estas mais estáveis em soluções ácidas do que em soluções neutras e alcalinas. Este autor também observou que, em certas faixas de $\mathrm{pH}$, a presença do oxigênio diminui consideravelmente a estabilidade destes pigmentos.

Lukton et al. (1956) mostraram que a taxa de destruição da pelargonidina 3 - glucosídeo, em sucos de morango a $45^{\circ} \mathrm{C}$ e na ausência de oxigênio, foi independente do pH. Entretanto, na presença de $\mathrm{O}_{2}$, a degradação aumentou consideravelmente com a variação do $\mathrm{pH}$. Estes autores também observaram o efeito deletério do oxigênio molecular sobre as antocianinas em sucos de uva engarrafados (passando de uma coloração brilhante púrpura a amarronzada), e concluíram que a mudança de coloração poderia ser altamente reduzida através do preenchimento completo das embalagens, diminuindo-se assim o contato do oxigênio com o suco.

Em suas pesquisas com purê de morango, Cash \& Sistrunk (1970), observaram que a coloração poderia ser estabilizada através do uso de alguns compostos químicos, como por exemplo o antioxidante $\mathrm{SnCl}_{2}$. Observaram também que o pH não foi um dos fatores marcantes na estabilidade da cor no purê de morango.

As transformações das antocianinas e os mecanismos de degradação da cor em produtos de morango, tais como conservas, geléias e sucos 
concentrados, foram intensivamente estudados por Spayd \& Morris (1982) e Spayd et al. (1982). A mudança de cor em produtos concentrados de morango é atribuída à degradação de antocianina monomérica para polimérica. Os pigmentos poliméricos são solúveis em hidróxido de sódio $(1,0 \mathrm{~N})$ e o emprego de aditivos químicos pode diminuir a formação desses pigmentos no purê de morango durante a estocagem. A adição de $\mathrm{NaHSO}_{3}$, ácido cítrico e $\mathrm{SnCl}_{2} \mathrm{em}$ morangos mecanicamente colhidos e congelados melhorou a cor após o congelamento, estocagem e descongelamento.

O efeito da temperatura na estabilidade das antocianinas em produtos alimentícios tem sido estudado por muitos autores. A explicação geral é que os pigmentos antociânicos são prontamente destruídos pelo calor, durante $\mathrm{o}$ processamento e armazenamento dos alimentos. A temperatura possui efeito altamente prejudicial sobre a pelargonidina 3 - glucosídeo, a principal antocianina presente no morango (Markakis, 1982).

Meschter ${ }^{2}$, citado por Markakis (1982), recomenda o processo HTST, a fim de se obter maior retenção do pigmento. Observou também que o ácido dehidroascórbico reage com as antocianinas, porém, em uma taxa consideravelmente menor em relação ao ácido ascórbico.

Adams \& Ongley ${ }^{3}$, também citados por Markakis (1982), mostraram que sucos de frutas vermelhas, enlatados a $100^{\circ} \mathrm{C}$ por menos de 12 minutos, resultam em perdas mínimas de antocianinas quando comparados com as que ocorrem durante um processamento lento e subsequente armazenamento em temperatura ambiente.

\footnotetext{
${ }^{2}$ MESCHTER, E. L. Journal of Agriculture and Food Chemistry, v.1, p.574-79, 1953.

${ }^{3}$ ADAMS, J.B. ; ONGLEY, M.H. Campden Food Pres. Res. Assoc. Tech. Bull. p. 23, 1972.
} 
Abers \& Wrolstad (1979) analisaram as diferenças na composição química de duas variedades de morango (Hood e Tioga) a fim de se determinar quais os fatores que contribuem para a rápida deterioração da cor que ocorre em conservas feitas com morangos da variedade Tioga. Estes autores concluíram que a rápida taxa de escurecimento se deve a uma concentração consideravelmente maior de compostos fenólicos reativos (leucoantocianinas e catequinas) nesta variedade em relação à Hood. Acredita-se que a reação destes fenóis, com posterior formação de compostos poliméricos escuros, é a principal causa da deterioração da cor nas conservas de morango.

Askar et al. (1994) estudaram os fatores que afetam a estabilidade da cor em néctar de manga. As mudanças de coloração foram determinadas através de cálculos relacionados entre os carotenóides totais e substâncias que causaram escurecimento no produto. Estes autores concluíram que a enzima polifenoloxidase foi inativada nos primeiros estágios do processamento da polpa da manga. A adição de ácido ascórbico durante o processamento foi recomendada, e a vida útil do néctar armazenado em temperatura ambiente não ultrapassou seis meses.

Khurdiya (1993) utilizou o néctar de algumas variedades de manga para proporcionar cor, sabor e textura aos néctares de outras frutas.

Wrolstad et al. (1990) estudaram o efeito de uma rápida congelação de morangos e posterior adição de sacarose, sobre a coloração desses frutos, após três anos de armazenamento a $15^{\circ} \mathrm{C}$. Estes pesquisadores observaram que a sacarose possui papel protetor no conteúdo dos pigmentos antociânicos, proporcionando um retardamento no escurecimento dos morangos, bem como na formação de polímeros. 
Hudson et al. (1977) adicionaram ácido cítrico em morangos congelados e observaram que este aditivo químico melhorou a estabilidade da cor, bem como a retenção do ácido ascórbico nos morangos. Os acidulantes desempenham funções importantes nas bebidas, pois abaixam $\mathrm{o} p H$ do produto, diminuindo a resistência dos microrganismos, tornando a bebida mais agradável ao paladar e seqüestram metais que possam causar alterações nas características organolépticas da bebida (Almeida, 1996b).

O efeito da polifenoloxidase na degradação da antocianina também foi analisado por Weshe-Ebeling \& Montgomery (1990). A enzima foi utilizada em combinação com a D-catequina ou com a pelargonidina e cianina. A reação da polifenoloxidase com a D-catequina induziu à formação de pigmentos marrom-amarelados. Já com a cianina, observou-se pequena reação, e nenhuma atividade com a pelargonidina. A polifenoloxidase, juntamente com a cianidina, causaram uma perda de $50-60 \%$ nos pigmentos antociânicos após 24 horas em temperatura ambiente, com a formação de precipitado.

Nelson et al. ${ }^{4}$, citados por Passos (1982), avaliaram a qualidade do morango congelado e encontraram correlações negativas significativas entre $o$ $\mathrm{pH}$ e a acidez titulável, entre o componente " $\mathrm{L}$ " da cor e a cor avaliada subjetivamente, e entre o componente "L" da cor e o sabor. A avaliação subjetiva da cor foi positivamente correlacionada com a aparência e com a firmeza, avaliada objetivamente no fruto in natura.

Bleinroth et al. (1977) e Salomón et al. (1977) estudaram a vida útil de dois tipos de néctares, elaborados a partir da mistura de abacaxi-maracujá e abacaxi-laranja, armazenados em temperatura ambiente por um período de

\footnotetext{
${ }^{4}$ NELSON, J.W.; BARRITT, B.H.; WOLFORD, E.R.; TORRE, L.C. Processing evaluation of strawberry cultivars grown in Western Washington. Pullman, College of Agriculture Research Center, Washington State University. 5p. 1976.
} 
seis meses. Foi observado um escurecimento dos produtos com o tempo de armazenamento, como também uma diminuição na viscosidade.

Pilando et al. (1985) observaram durante seis semanas de armazenamento, a composição dos vinhos de morango obtidos de frutos amadurecidos, superamadurecidos e contaminados por fungos. Os frutos superamadurecidos, os quais apresentavam maiores teores de antocianina e compostos fenólicos, originaram vinhos com melhor coloração em relação aos frutos amadurecidos. A contaminação fúngica aumentou a viscosidade do suco e acelerou a degradação da cor. Estes autores acreditam que as enzimas derivadas da atividade fúngica apresentam importante função na degradação dos pigmentos antociânicos, bem como contribuem para as reações de escurecimento.

Os efeitos da contaminação fúngica na estabilidade do suco de morango também foram estudados por Rwabahizi \& Wrolstad (1988). Estes autores observaram que a contaminação fúngica elevou significativamente o teor de polímeros, provocando um escurecimento nos sucos, e que o processo de ultrafiltração acelerou a perda de antocianinas monoméricas durante a concentração do produto. Os concentrados preparados por filtração convencional apresentaram cor mais aceitável e aparência melhor do que os concentrados por ultrafiltração.

Speers et al. (1987) estudaram a taxa de mudança da coloração vermelha para marrom em suco de morango a $20^{\circ}, 30^{\circ}$ e $45^{\circ} \mathrm{C}$, após doze semanas de armazenamento. Foi desenvolvido um modelo para explicar o aumento da degradação da coloração utilizando reações cinéticas de primeira ordem. As constantes de reação, no aumento da cor marrom e na perda da cor vermelha, foram maiores a $45^{\circ} \mathrm{C}$ do que a $35^{\circ} \mathrm{C}$. $\mathrm{O}$ modelo de primeira ordem 
desenvolvido foi preciso na predição das taxas em relação ao aumento da coloração marrom a $35^{\circ}$ e $45^{\circ} \mathrm{C}$ e as taxas de perda de cor vermelha a $20^{\circ}, 30^{\circ}$ e $45^{\circ} \mathrm{C}$.

A estabilidade da cor em xaropes de morango e amora a $51^{\circ} \mathrm{Brix}$ foi analisada por Skrede et al. (1992). Estes autores observaram que os pigmentos antociânicos apresentaram-se menos estáveis no xarope de morango do que no xarope de amora. Conseqüentemente, a estabilidade da cor depende mais da concentração total de antocianina do que da composição qualitativa do pigmento. Observaram também que a adição de ácido ascórbico diminuiu a estabilidade da cor no xarope de morango.

Sucos concentrados de morango $\left(68^{\circ}\right.$ Brix) foram estocados a $20^{\circ} \mathrm{C}$, por 6 dias. As amostras foram analisadas para se determinar alterações em relação ao gosto, aroma e coloração dos sucos. Estes, após 6 dias de armazenamento, apresentaram alterações como gosto adstringente, "aroma de bolor" e coloração marrom. Estas perdas na qualidade foram acompanhadas de uma produção de $\mathrm{CO}_{2}$ e redução na concentração de aminoácidos livres, enquanto que os açúcares redutores e a acidez titulável se mostraram estáveis (Lundahl et al., 1989).

Askar et al. (1996) observaram o efeito do tipo de embalagem em função do tempo de armazenamento em néctar de pêssego, pasteurizado a $95^{\circ} \mathrm{C}$ por 60 segundos e acondicionado a quente em latas e garrafas de vidro, armazenado a $37^{\circ} \mathrm{C}$, por 12 meses. O tempo de armazenamento, a temperatura de estocagem, bem como o tipo de embalagem, apresentaram um pequeno efeito sobre os sólidos solúveis, acidez total e conteúdo de cálcio no néctar. Após seis meses de armazenamento, o néctar ficou inaceitável quanto à cor e sabor. $\mathrm{O}$ conteúdo de vitamina $\mathrm{C}$ diminuiu e o grau de descoloração 
aumentou com o tempo de armazenamento. A deterioração da cor foi menor nas embalagens de lata do que nas garrafas de vidro.

Uygun \& Acar (1995) estudaram o efeito do $\mathrm{pH}$, ions metálicos $\left(\mathrm{FeCl}_{3} \cdot 6 \mathrm{H}_{2} \mathrm{O}\right.$ ou $\left.\mathrm{SnCl}_{2}\right)$ e tempo de armazenamento sobre a cor em néctares de cereja, pasteurizados a $85^{\circ} \mathrm{C}$ por 20 minutos e armazenados a $20^{\circ} \mathrm{C}$ ou $4^{\circ} \mathrm{C}$ por três meses. Os resultados mostraram que o teor de antocianinas, analisado a cada trinta dias, diminuiu em todas as amostras de néctar durante as primeiras quatro semanas de armazenamento. A principal perda de pigmento ocorreu em amostras que continham $\mathrm{FeCl}_{3} \mathrm{em} \mathrm{pH}$ 4. Observou-se também que, a perda dos pigmentos aumentou com a elevação do $\mathrm{pH}$ e que o armazenamento refrigerado apresentou um efeito estabilizador no néctar de cereja.

\subsection{2 - Variedades de morango}

A seleção de variedades mais apropriadas para uma circunstância particular de produção é um fator muito importante. Muitas variedades têm a capacidade de reter sua qualidade na fase pós-colheita devido às suas características genéticas, bioquímicas e fisiológicas endógenas, bem como a determinadas características físicas (Chitarra \& Chitarra, 1990).

No Brasil, a partir dos anos sessenta, a introdução de variedades mais adaptadas e de novas técnicas de cultivo, bem como a maior oferta de mudas com sanidade controlada, contribuíram para o maior desenvolvimento da cultura do morangueiro (Castellane, 1991).

De acordo com Murayama (1983) e Padovani (1991), todas as variedades de morango cultivadas atualmente são muito distintas entre si no 
que diz respeito às condições ecológicas, bem como em relação à forma, cor, sabor, tamanho, produtividade, época de maturação e resistência às pragas e doenças. As únicas variedades plantadas comercialmente no centro-sul de São Paulo são os clones produzidos no Instituto Agronômico de Campinas (IAC), resultantes do melhoramento genético, envolvendo cruzamentos entre algumas espécies do gênero Fragaria (Filgueira, 1982).

Mc Cance \& Widdowson's (1994) estudaram a composição de diversos alimentos, dentre os quais o morango, o qual apresenta os seguintes elementos, expressos em g/100g de fruta: água $(89,5)$; açúcares totais $(6,0)$; carboidratos $(6,0)$; proteína $(0,8)$; gordura $(0,1)$; e em mg/100 de morango: vitamina C (77,0); $\mathrm{Na}(6,0) ; \mathrm{K}(160) ; \mathrm{Ca}(16) ; \mathrm{Mg}(19,0) ; \mathrm{P}(24,0)$ e Fe $(0,4)$.

Paschoalino (1989) ressalta que a seleção de variedades, a região de cultivo, as práticas culturais e o estágio de maturação na colheita, bem como o manuseio do produto, são fatores importantes a serem considerados, uma vez que a matéria-prima é essencial para a qualidade e característica do produto final. Morris et al. (1985) estudaram os efeitos de duas variedades e do manuseio pós-colheita de morangos frescos, na qualidade do processamento destes. O excessivo manuseio pós-colheita diminuiu a qualidade dos frutos em ambas as variedades, sendo maior a perda em frutos da variedade com características mais sensiveis ao manuseio.

Wrolstad et al. (1990) observaram que a composição química dos sucos de frutas concentrados depende da variedade, maturidade, clima e práticas culturais, sendo estes parâmetros responsáveis pelas mudanças químicas que ocorrem durante o processamento e armazenamento destes produtos. 
O clone Guarani (IAC-5074) foi obtido do cruzamento, realizado em 1974, entre os cultivares Campinas x Monte Alegre e o cultivar Alemanha. A variedade Guarani possui boa produtividade precoce e número total de frutos, competindo nestes aspectos com as variedades Campinas e Monte Alegre. Apresenta também boa estabilidade de produção ao longo de três anos de cultivo, frutos com boa qualidade para industrialização, devido à intensa coloração externa e interna, ao tamanho e à boa firmeza, tendo também um bom desempenho durante a congelação. Esta variedade apresenta maior grau de resistência à Mycosphaerella fragarie do que as variedades Campinas e Monte Alegre, e um pH ao redor de 3,46 (Passos, 1982).

A variedade Oso Grande foi desenvolvida na Califórnia e está sendo cultivada no Brasil com bastante sucesso, desde meados de 1994. É caracterizada por apresentar uma textura firme, aparência brilhante, um sabor pronunciado, tamanho relativamente grande e pH próximo de 3,81 . O sucesso alcançado pela cultura do morango, na Califórnia, é devido ao trabalho de melhoramento genético, com a obtenção de novos cultivares e, paralelamente, também ao desenvolvimento de novas técnicas culturais e à manipulação fisiológica destes novos materiais (Tessarioli Neto, 1993).

Segundo Abers \& Wrolstad (1979), determinadas variedades de morango são caracterizadas por proporcionarem produtos com cores mais aceitáveis quando comparadas com outras. A variedade Hood, por exemplo, é considerada por alguns pesquisadores, por produzir conservas de morango com melhor estabilidade de cor do que a variedade Tioga.

Szilagyi \& Marton (1987) avaliaram duas novas variedades de morango: Kortes e Hakra's Romata, em relação à composição química e atributos organolépticos, bem como a adaptação destas ao processamento. Os 
resultados mostraram que a variedade Kortes apresentava polpa escurecida e se prestava ao consumo in natura e enlatamento. A variedade Hakra's Romata, que era bastante aromática, foi somente aceita a nível de consumo in natura.

Dovillard \& Guichard (1989) e Shenshina et al. (1993) também estudaram a composição química de certas variedades de morango e observaram diferenças consideráveis em relação ao teor de álcool, lactonas e ésteres, os quais implicam em diferentes características sensoriais. Stanley (1988) estudou amostras de treze variedades quanto ao enlatamento e congelação e observou que cada grupo apresentou diferentes características em relação à textura, sabor e cor.

Berbari et al. (1994) determinaram as características físicas, químicas e sensoriais de quatro novas variedades de morango (Sequóia, Chandler, Reiko e IAC - Princesa (sabel), visando avaliar a qualidade destas à conservação por congelação. Os resultados mostraram que a variedade Chandler foi a que apresentou características mais apropriadas para este tipo de processamento, sendo superior às demais em textura e cor, principais atributos de qualidade para o produto congelado.

Richards (1996) avaliou a qualidade das variedades Chandler e Reiko para a obtenção de morango em calda, e também observou que a Chandler foi a que apresentou características mais apropriadas para o tratamento térmico, sendo superior à variedade Reiko em textura e cor.

Aradhita et al. (1995) analisaram a vida útil do néctar de goiaba, armazenado por noventa dias à temperatura ambiente, e observaram um aumento linear, na taxa de escurecimento, teor de sólidos solúveis totais, acidez total e uma redução no teor de ácido acórbico e na qualidade 
organoléptica. O néctar de melhor qualidade foi aquele preparado de variedades híbridas, ao invés de variedades comerciais.

De acordo com Passos (1982), deve-se distinguir as exigências dos vários tipos de processamento para os quais a variedade será utilizada. Visando a manutenção da forma do fruto de interesse para congelação e confecção de compotas, há necessidade de uma textura rígida. As variedades Alemanha, Tioga, Guarani e IAC - 1436 apresentam essa característica. Em suas pesquisas, esse autor ressalta que a variedade Guarani também apresentou a coloração interna mais intensa, o que seria de interesse na conservação da cor por vários meses, no processo de congelação e também na possibilidade de substituir em parte o uso de corantes.

\subsection{3 - Ácido ascórbico}

A composição natural de um mesmo tipo de alimento pode variar muito com a procedência, variedade, trato cultural, etc. Além desta diferença natural, as vitaminas e os minerais podem ser perdidos nas várias etapas de produção, distribuição ou mesmo preparo doméstico de um alimento (Carvalho, 1995).

Segundo Eskin (1991), o ácido ascórbico é um dos componentes mais importantes e pesquisados em morangos. As frutas frescas são fontes ricas dessa vitamina, fornecendo de 50 a $90 \mathrm{mg} / 100 \mathrm{~g}$, valores estes que variam grandemente entre variedades e condições de cultivo. 
Kantor et al. (1984) testaram dez variedades de morangos e os resultados mostraram que os níveis de açúcares variaram de 5,13 a 6,90\% e o teor de ácido ascórbico de 40 a 50mg/100g.

A perda da qualidade nutricional durante o processamento e a estocagem de alimentos tem se tornado um problema crescente com a introdução dos regulamentos de classificação nutricional. Para aumentar o valor nutritivo de alimentos processados, muitos produtos são agora enriquecidos com vitaminas e minerais (Prado,1994).

Durante o processamento, fatores como calor, luz, agentes oxidantes e pH contribuem para a diminuição dos níveis vitamínicos. $\mathrm{O}$ calor, utilizado geralmente para a alteração da estrutura dos tecidos de um alimento, destruição de microrganismos ou mesmo para a inativação de enzimas, pode alterar significativamente os teores de nutrientes, principalmente se sua utilização for acompanhada pela incorporação de ar (oxigênio) ou água. Algumas vitaminas podem ser rapidamente degradadas, como a vitamina C (antioxidante natural), que é facilmente perdida em processos oxidativos (Carvalho, 1995).

De acordo com Andrade \& Camargo (1989), a tecnologia de alimentos pode utilizar os aditivos como recurso para compensar as perdas inevitáveis de nutrientes, mesmo após a escolha dos métodos mais adequados. São os aditivos nutricionais, que compreendem as vitaminas, proteínas, aminoácidos essenciais e minerais. O enriquecimento consiste em aumentar o nível nutricional já existente no produto.

Segundo Johnson (1995), a evidência de que os nutrientes oxidantes (vitamina $\mathrm{C}$, vitamina $\mathrm{E}$ e beta caroteno) são importantes para a saúde humana 
vem crescendo rapidamente. $\mathrm{O}$ conhecimento adquirido pelos nutricionistas e bioquímicos exigem técnicas adequadas, a fim de se obter melhor retenção destes nutrientes.

Várias propriedades destes componentes são importantes para os cientistas de alimentos, já que o gosto, por exemplo, é um importante atributo sensorial que pode afetar as características finais do sabor do alimento ao qual o nutriente é adicionado. As pessoas não consomem alimentos com sabor desagradável. $\mathrm{O}$ ácido ascórbico possui gosto ácido e a maioria dos alimentos enriquecidos com esta vitamina possui pH abaixo de 7 .

A adição de vitaminas e minerais em um alimento e a permissão para que esse produto seja rotulado como "enriquecido" tem feito com que, em vários casos, estes procedimentos sejam também utilizados como apelo de "marketing" (Carvalho, 1995).

O ácido ascórbico é comumente chamado de "a vitamina dos alimentos frescos". Ocorre em partes da planta em crescimento, mas está ausente nas sementes. As frutas e os vegetais são as principais fontes, e a necessidade está em torno de $70 \mathrm{mg} /$ dia para uma pessoa normal. A vitamina C é essencial para a construção dos tecidos cimentantes que unem as células dos tecidos, mantendo firmes os dentes na cavidade dentária, ossos unidos e firmeza dos vasos sangüíneos. Auxilia na absorção de cálcio e ferro e participa da absorção de certos aminoácidos e da síntese de hormônios. Protege contra infecções e é essencial na cicatrização de ferimentos. A maior ingestão de vitamina $C$ recomendada em resfriados se deve a esse fato, porém, os tecidos mantêm um nível de saturação normal e o excesso não é aproveitado pelo organismo, sendo excretado pela urina (Andrade \& Camargo, 1989). 
Segundo Chitarra \& Chitarra (1990), cerca de 90\% das necessidades de vitamina $C$ do ser humano advêm de frutos e hortaliças. Ela é o componente nutricional mais importante destes alimentos e os frutos cítricos são considerados como as melhores fontes, não só pelo teor dessa vitamina (50 a $75 \mathrm{mg} / 100 \mathrm{ml}$ de suco) como pelo seu elevado consumo, nas dietas do mundo inteiro.

A principal causa da degradação da vitamina $C$ é a oxidação aeróbica ou esurecimento enzímico, ambas levando à formação de furaldeídos, compostos que polimerizam facilmente, com a formação de pigmentos escuros. É também rapidamente destruída pela luz. Embora, de modo geral, a estabilidade da vitamina $\mathrm{C}$ aumente com $\mathrm{o}$ abaixamento da temperatura, a maior perda ocorre o armazenamento de alimentos em baixas temperaturas (Bobbio \& Bobbio, 1989).

Goldoni et al. (1981) observaram perdas altamente significativas de ácido ascórbico durante o armazenamento do suco integral de morango, sendo que o valor das médias dos tratamentos pasteurizados foi de $25,16 \mathrm{mg} / 100 \mathrm{~g}$. Em relação aos valores de pH, Berbari et al.(1994) e Richards (1996), observaram que praticamente não houve variação com a diminuição no teor de ácido ascórbico durante o armazenamento de morangos congelados e em calda, respectivamente.

Agganwal et al. (1992) avaliaram a adequabilidade de duas variedades de pêssego para o processamento de néctar, geléia e pêssego em calda. Os produtos apresentaram ótimas qualidades quanto à aparência, sabor e textura. $\mathrm{O} \mathrm{pH}$, acidez total e sólidos solúveis, em todos os produtos, permaneceram estáveis durante seis meses de armazenamento, com exceção 
do ácido ascórbico, o qual diminuiu continuamente, apresentando uma perda total de vitamina $\mathrm{C}$ ao longo do período de armazenamento do néctar.

A qualidade do néctar de manga enlatado foi estudado por Askar et al. (1993). Estes autores observaram que a desaeração e o enchimento das latas a quente foram importantes na redução do teor de oxigênio no néctar e que o armazenamento em baixas temperaturas foi um dos melhores métodos de prevenção das perdas de sabor, cor e vitamina C. O armazenamento e manuseio em temperaturas maiores do que $21^{\circ} \mathrm{C}$ (como normalmente é feito) reduziram em seis meses a vida útil do néctar de manga enlatado.

Otto (1984) armazenou sucos e néctares de sete frutas acondicionados em embalagens de vidro. As amostras foram analisadas em intervalos de 4 a 6 semanas em relação ao ácido ascórbico, formação de hidroximetilfurfural, mudanças de coloração e qualidade organoléptica. Os resultados indicaram que os limites químicos de tolerância em relação à perda de vitamina $C$ e mudanças na coloração, não são necessariamente idênticos aos limites de tolerância sensorial.

Gofur et al. (1994) estudaram a composição química do néctar de manga engarrafado e armazenado em temperatura ambiente, por 380 dias. Com exceção do teor de vitamina $\mathrm{C}$, o qual diminuiu já no início do armazenamento, os outros parâmetros como cor, acidez, pH e sólidos solúveis totais não apresentaram mudanças significativas aos 360 dias de armazenamento do produto. Posteriormente, a deterioração da cor e do sabor foram também observados. 


\section{4 - MATERIAL E MÉTODOS}

As atividades desta pesquisa foram conduzidas em laboratório do Departamento de Ciência e Tecnologia Agroindustrial da Escola Superior de Agricultura "Luiz de Queiroz" - USP - Campus de Piracicaba - São Paulo.

\subsection{Matéria-prima}

No presente trabalho foram utilizadas as variedades de morangos Guarani e Oso Grande, por possuírem características favoráveis para a elaboração de néctares, conforme resultados obtidos em testes preliminares deste trabalho, e também, por não estarem, até então, incluídas em pesquisa a nivel de processamento.

Foram recebidos no laboratório do Departamento de Ciência e Tecnologia Agroindustrial, lotes de $15 \mathrm{~kg}$ de morango (Fragaria ananassa Duch.) de cada uma das variedades em estudo, provenientes da cidade de Jarinu (região de Atibaia), Estado de São Paulo.

As amostras foram levadas ao laboratório no mesmo dia da colheita e refrigeradas $\left(3\right.$ a $4^{\circ} \mathrm{C}$ ), sendo o material selecionado e processado dentro de um período máximo de 48 horas após seu recebimento. 
Os frutos processados apresentavam ótimas condições para o consumo in natura e estavam no seu ponto ótimo de colheita, ou seja quando estes apresentavam $75 \%$ de sua superfície externa com coloração vermelha (Filgueira, 1982).

\subsection{Caracterização da Matéria-prima}

\subsubsection{Análises físicas}

a) Rendimento: para as determinações de rendimento da matériaprima, foram utilizadas amostras de $1000 \mathrm{~g}$ de frutos, tomadas aleatoriamente dos lotes do material.

Inicialmente, os morangos foram pesados em balança semi-analítica; a seguir foram limpos, lavados em água corrente e drenados por 15 minutos, sendo então, novamente pesados. Os resultados são expressos em porcentagem do peso da matéria-prima pronta para o processamento, em relação ao peso original da matéria-prima.

b) Textura: para as determinações da textura dos frutos, foi utilizado o "Texture Testing System" (texturômetro), modelo Tp-1, acoplado a um registrador automático de variações de força, operando com célula-padrão de compressão e cisalhamento CS-1, com 10 lâminas de 1/8 polegada de espessura e ângulo de $90^{\circ}$. $O$ instrumento estava provido de um sensor eletrônico de $300 \mathrm{lbf}$ e a velocidade de descida do pistão foi de $20 \mathrm{~cm} /$ minuto. 
As amostras foram previamente pesadas ( $50 \mathrm{~g}$ de morangos inteiros sem cálice) e colocadas ao acaso na célula-teste. Os resultados são apresentados em lbf/g de amostra.

c) Suculência: para as determinações de suculência dos frutos foi utilizado o "Texture Testing System", empregando a célula-padrão de suculometria CR-1 (succulometer cell). O instrumento estava provido de um anel sensor de $3.000 \mathrm{lbf}$ e a velocidade de descida do pistão foi de 20 $\mathrm{cm} /$ minuto.

As amostras foram previamente pesadas $(50 \mathrm{~g}$ de morangos inteiros sem os cálices) e colocadas ao acaso na célula-teste, sendo o volume de suco liberado, coletado em proveta graduada de $50 \mathrm{ml}$. Os dados apresentados correspondem ao volume de suco liberado ( $\mathrm{ml}$ ) por grama de amostra, quando submetida a uma força máxima de compressão, pelo tempo de 2 minutos.

Todas as determinações foram efetuadas com 2 repetições em amostras tomadas aleatoriamente dos lotes das duas variedades de morango.

\subsection{2 - Análises químicas}

a) Ácido ascórbico: foi determinado por extração em ácido oxálico e titulação, segundo Método de Tillmans (Ranganna, 1977).

Amostras de $10 \mathrm{~g}$ de morangos foram trituradas em liqüidificador com $50 \mathrm{ml}$ de ácido oxálico a 4:1000, durante três minutos. A seguir, a mistura foi passada para um balão volumétrico de $100 \mathrm{ml}$. 0 copo do liqüidificador foi 
lavado com porções de $20 \mathrm{ml}$ de ácido oxálico, que eram adicionadas ao balão volumétrico de $100 \mathrm{ml}$, até completar o volume. O conteúdo do balão foi filtrado e $2 \mathrm{ml}$ deste foram pipetados para um erlenmeyer de $125 \mathrm{ml}$ e adicionados $50 \mathrm{ml}$ de água destilada; a seguir foi titulado sob agitação, com solução corante de 2,6 diclorofenolindofenol. Os teores de ácido ascórbico das amostras foram calculados tomando-se por base um padrão de ácido ascórbico, previamente determinado. Os resultados são expressos em $\mathrm{mg}$ de ácido ascórbico por $100 \mathrm{~g}$ da amostra.

b) Acidez total titulável: na determinação da acidez total titulável, $10 \mathrm{~g}$ de néctar foram diluídos em $90 \mathrm{ml}$ de água destilada e titulados com solução de hidróxido de sódio $0,1 \mathrm{~N}$, tendo como indicador a fenolftaleína a $1 \%$, conforme Kanesiro et al. (1982). Os resultados são expressos em gramas de ácido cítrico por $100 \mathrm{~g}$ de néctar de morango.

c) pH: foi determinado em potenciômetro Alphalab, modelo PA-200. Os resultados são expressos em unidades de pH.

d) Sólidos solúveis totais: foram determinados em refratômetro Atago, modelo $\mathrm{N}-1$. Os resultados são expressos em ${ }^{\circ}$ Brix (Tressler \& Joslyn, 1961).

Todas as análises químicas foram efetuadas com duas repetições, utilizando amostras tomadas ao acaso dos lotes das duas variedades de morango. 


\section{3 - Processamento dos morangos}

\subsection{1. - Néctar comum}

As operações utilizadas para a obtenção do néctar comum de morango estão indicadas na Figura 1. Após recebimento dos lotes de morango no laboratório, os frutos foram imediatamente selecionados, os cálices removidos e em seguida lavados em água corrente e drenados por cerca de 15 minutos. Cada lote de morangos $(6 \mathrm{~kg})$ foi desintegrado em despolpadeira mecânica ITAMETAL, modelo $0.25 \mathrm{df}$, com peneira de $0,6 \mathrm{~mm}$, obtendo-se assim o purê, o qual foi misturado manualmente ao xarope de sacarose.

O néctar elaborado consistiu da mistura, em peso, de 50 partes de purê e 50 partes de xarope de sacarose com ${ }^{\circ}$ Brix suficiente para se obter 0 néctar com Brix de equilíbrio ao redor de $13^{\circ}$. Com a aplicação de calor durante a pasteurização, ocorre uma pequena concentração e maior troca osmótica entre a sacarose dos frutos, ocasionando uma elevação no teor de sólidos solúveis do néctar (de $13^{\circ}$ para $14^{\circ} \mathrm{Brix}$ ). A seguir, o néctar foi homogeneizado, aplicando-se os tratamentos e pasteurizado por aquecimento em banho-maria, em recipientes de aço inox, até atingir a temperatura de $90^{\circ} \mathrm{C}$, com um tempo de retenção de 15 segundos nesta temperatura, estando assim, pronto para o acondicionamento, recravação, resfriamento e armazenamento à temperatura ambiente.

O néctar comum das duas variedades de morango apresentou os seguintes valores por lata: 207,55 cal e 45,5 g açúcar ( 35 g adicionado + $10,5 \mathrm{~g}$ da fruta).

Os tratamentos aplicados estão esquematizados na Figura 2. 


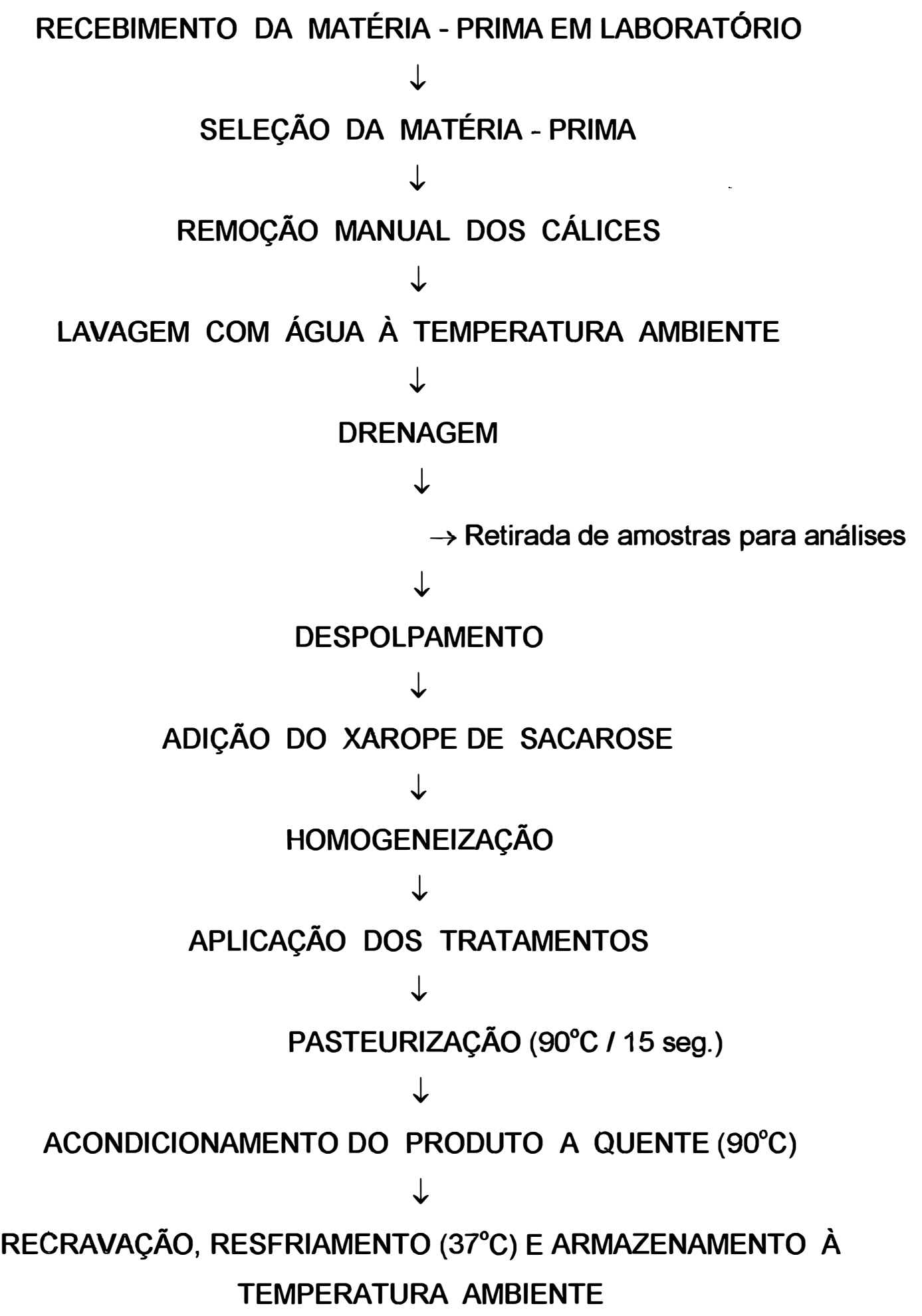

Figura1. Fluxograma das operações utilizadas para obtenção do néctar comum. 


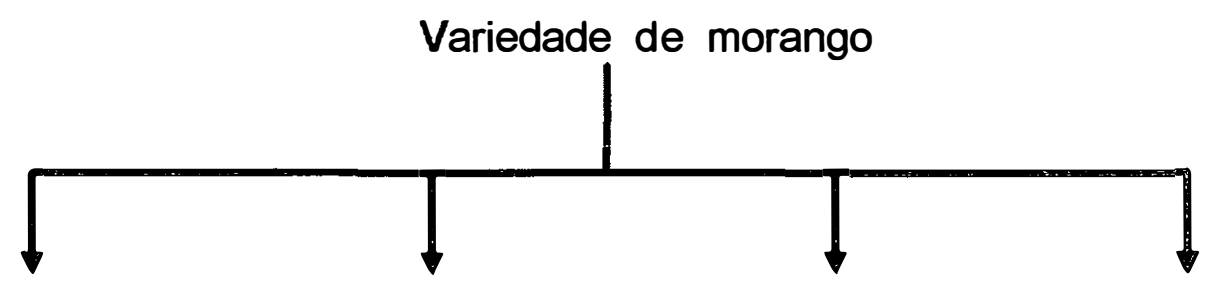

purê de morango purê de morango purê de morango purê de morango $+$

xarope de

xarope de

xarope de

xarope de

sacarose

sacarose

sacarose

sacarose

$+$

$+$

$+$

sorbato de

sorbato de

sorbato de

potássio

potássio

potássio

$+$

$+$

$+$

cloreto de

cloreto de

cloreto de

estanho

estanho

estanho

$+$

$+$

ácido cítrico

ácido cítrico

$+$

ácido ascórbico

Figura 2. Fluxograma dos tratamentos aos quais cada variedade de morango foi submetida para obtenção do néctar comum. 


\section{A) Tratamentos para a obtenção do néctar comum}

\section{Tratamento 1 (Testemunha) : purê de morango + xarope de sacarose}

Após o preparo e despolpamento dos frutos, um lote de $2.500 \mathrm{~g}$ de purê de morango a $5,26^{\circ} \mathrm{Brix}$ (variedade Guarani) e outro lote de mesmo peso a $8,62^{\circ} \mathrm{Brix}$ (variedade Oso Grande) foram misturados, respectivamente, com $2.500 \mathrm{~g}$ de xarope de sacarose a $20,7^{\circ} \mathrm{Brix}$ (variedade Guarani) e $2.500 \mathrm{~g}$ do xarope a $17,4^{\circ} \mathrm{Brix}$ (variedade Oso Grande), a fim de se obter o néctar, de cada variedade, a $13^{\circ}$ Brix (selecionado em testes preliminares).

\section{Tratamento 2: purê de morango + xarope de sacarose + sorbato de potássio + cloreto de estanho}

Este tratamento seguiu o mesmo procedimento que o tratamento 1, porém, com adição de $0,1 \%$ de sorbato de potássio e $0,0025 \%$ de cloreto de estanho em relação ao peso do néctar. $O$ sorbato de potássio foi utilizado como conservante e o cloreto de estanho como estabilizante químico da cor, já que as latas não eram estanhadas. As quantidades adicionadas estão dentro dos limites permitidos pela Legislação brasileira (Brasil, 1988b).

\section{Tratamento 3: purê de morango + xarope de sacarose + sorbato de potássio + cloreto de estanho + ácido cítrico}

Este tratamento seguiu o mesmo procedimento que o tratamento 2, porém, com adição de ácido cítrico em quantidade suficiente para reduzir o pH do néctar até o valor próximo de 3,3 (Brasil, 1988b). 


\section{Tratamento 4 : purê de morango + xarope de sacarose + sorbato de potássio + cloreto de estanho + ácido cítrico + ácido ascórbico}

Este tratamento seguiu o mesmo procedimento que o tratamento 3, porém, com adição de $0,03 \%$ de ácido ascórbico em relação ao peso do néctar. O ácido ascórbico foi adicionado como antioxidante e para a revitaminação do produto. A quantidade adicionada está dentro do limite permitido pela Legislação brasileira (Brasil, 1988b).

\subsection{2 - Néctar dietético}

O néctar dietético consistiu da mistura, em peso, de 50 partes de purê e 50 partes de xarope de edulcorantes (sorbitol + esteviosídeo) com ${ }^{\circ}$ Brix suficiente para se obter o néctar com Brix de equilíbrio ao redor de $13^{\circ}$. As operações utilizadas para a obtenção do néctar dietético estão indicadas na Figura 3.

O néctar dietético das duas variedades de morango apresentou os seguintes valores por lata: 205,45 cal e $10,5 \mathrm{~g}$ de açúcar da fruta.

Os tratamentos aplicados à variedade Oso Grande estão esquematizados na Figura 4. Para a variedade Guarani foram aplicados somente três tratamentos. Nesta, os tratamentos 1 e 2 foram idênticos aos aplicados à variedade Oso Grande e o tratamento 3 consistiu de: purê de morango + xarope de edulcorantes + sorbato de potássio + cloreto de estanho + ácido ascórbico. 


\section{A) Tratamentos para a obtenção do néctar dietético}

Tratamento1 (Testemunha): purê de morango + xarope de edulcorantes

Após o preparo e despolpamento dos frutos, um lote de $2.500 \mathrm{~g}$ de purê de morango a $5,26^{\circ} \mathrm{Brix}$ (variedade Guarani) e outro lote de mesmo peso a $8,62^{\circ}$ Brix (variedade Oso Grande) foram, respectivamente, misturados com $2.500 \mathrm{~g}$ de xarope de edulcorantes (97\% de sorbitol e $3 \%$ de esteviosídeo) a $20,7^{\circ} \mathrm{Brix}$ (variedade Guarani) e $2.500 \mathrm{~g}$ do xarope a $17,4^{\circ} \mathrm{Brix}$ (variedade Oso Grande), a fim de se obter o néctar, para cada variedade, a $13^{\circ} \mathrm{Brix}$ (selecionado em testes preliminares). A seguir, os néctares foram homogeneizados e pasteurizados, por aquecimento em banho-maria, em recipientes de aço inox, até atingir a temperatura de $90^{\circ} \mathrm{C}$, com um tempo de retenção de 15 segundos, estando pronto para o acondicionamento.

\section{Tratamento 2: purê de morango + xarope de edulcorantes + sorbato de potássio + cloreto de estanho}

Este tratamento (idêntico para as duas variedades) seguiu o mesmo procedimento que o tratamento 1 , porém, com adição de $0,1 \%$ de sorbato de potássio e $0,0025 \%$ de cloreto de estanho em relação ao peso do néctar. 0 sorbato de potássio foi utilizado como conservante e o cloreto de estanho como um estabilizante químico da cor, já que as latas não eram estanhadas. As quantidades adicionadas estão dentro dos limites permitidos pela Legislação brasileira (Brasil, 1988b). 
Tratamento 3 (somente para a variedade Oso Grande): purê de morango xarope de edulcorantes + sorbato de potássio + cloreto de estanho + ácido cítrico

Este tratamento seguiu o mesmo procedimento que o tratamento 2, porém, com adição de ácido cítrico em quantidade suficiente para reduzir o $\mathrm{pH}$ do néctar até o valor próximo de 3,3 (Brasil, 1988b).

Tratamento 4 (somente para a variedade Oso Grande): purê de morango + xarope de edulcorantes + sorbato de potássio + cloreto de estanho + ácido cítrico + ácido ascórbico

Este tratamento seguiu o mesmo procedimento que o tratamento 3, porém, com adição de $0,03 \%$ de ácido ascórbico em relação ao peso do néctar. $\mathrm{O}$ ácido ascórbico foi adicionado como antioxidante e para enriquecimento nutricional do produto. A quantidade adicionada está dentro do limite permitido pela Legilação brasileira (Brasil, 1988b).

Tratamento 3 (somente para a variedade Guarani): purê de morango + xarope de edulcorantes + sorbato de potássio + cloreto de estanho + ácido ascórbico

Este tratamento seguiu o mesmo procedimento que o tratamento 2, porém, com adição de $0,03 \%$ de ácido ascórbico em relação ao peso do néctar. $\mathrm{O}$ ácido ascórbico foi adicionado como antioxidante e para enriquecimento nutricional do produto. A quantidade adicionada está dentro do limite permitido pela Legilação brasileira (Brasil, 1988b). 


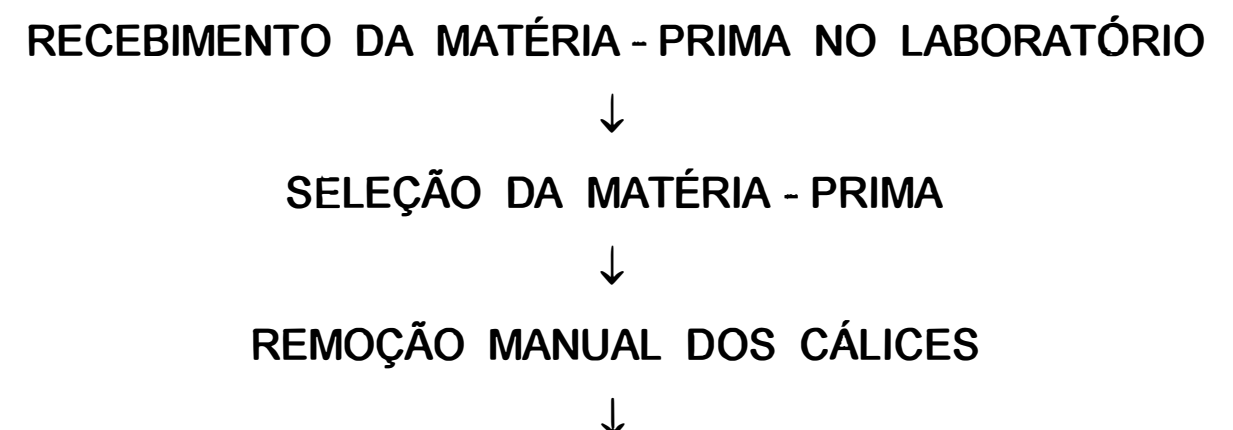

LAVAGEM COM ÁGUA À TEMPERATURA AMBIENTE

$\downarrow$

DRENAGEM

$\downarrow$

$\rightarrow$ Retirada de amostras para análises

$\downarrow$

DESPOLPAMENTO

$\downarrow$

ADIÇÃO DO XAROPE DE EDULCORANTES

$\downarrow$

HOMOGENEIZAÇÃO

$\downarrow$

APLICAÇÃO DOS TRATAMENTOS

$\downarrow$

PASTEURIZAÇÃO $\left(90^{\circ} \mathrm{C} / 15\right.$ seg. $)$

ACONDICIONAMENTO DO PRODUTO A QUENTE $\left(90^{\circ} \mathrm{C}\right)$

$\downarrow$

RECRAVAÇÃO, RESFRIAMENTO $\left(37^{\circ} \mathrm{C}\right)$ E ARMAZENAMENTO À

TEMPERATURA AMBIENTE

Figura 3 - Fluxograma das operações utilizadas para obtenção do néctar dietético. 


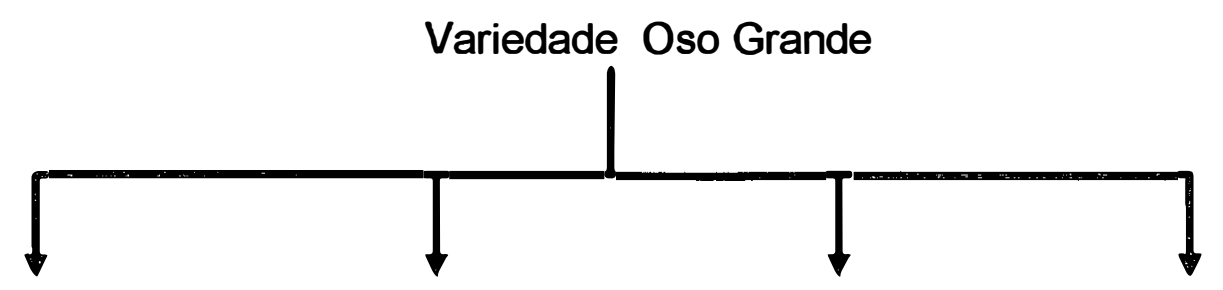

purê de morango purê de morango purê de morango purê de morango

$+$

xarope de

edulcorantes

\begin{abstract}
xarope de
edulcorantes

$+$

sorbato de

potássio
\end{abstract}

$+$

cloreto de

estanho xarope de

edulcorantes

$+$

sorbato de

potássio

$+$

cloreto de

estanho

$+$

ácido cítrico xarope de

edulcorantes

$+$

sorbato de

potássio

$+$

cloreto de

estanho

$+$

ácido cítrico

$+$

ácido ascórbico

Figura 4. Fluxograma dos tratamentos aos quais a variedade de morango Oso Grande foi submetida para obtenção do néctar dietético. 
Os edulcorantes não possuem a capacidade de "mascarar"o gosto ácido de um produto, como é o caso da sacarose. Assim sendo, ao néctar dietético da variedade Guarani não foi aplicado o tratamento com adição de ácido cítrico, uma vez que esta variedade já apresenta um pH natural mais baixo $(3,46)$ em relação à Oso Grande.

\subsection{3 - Acondicionamento}

$\mathrm{O}$ acondicionamento dos néctares das duas variedades de morango foi feito a quente $\left(90^{\circ} \mathrm{C}\right)$ em latas metálicas de folha-de-flandres, com capacidade de $410 \mathrm{~g}(74,6 \times 95,2 \mathrm{~mm})$, revestidas internamente com verniz epóxi, próprias para produtos ácidos. Em cada lata foram colocados cerca de $350 \mathrm{~g}$ de néctar de morango, deixando um espaço livre de aproximadamente $5 \mathrm{~mm}$.

\subsection{4. - Recravação}

Após o preenchimento do volume das latas com o néctar de morango, estas foram recravadas com 0 auxílio de recravadeira mecânica e posteriormente invertidas, a fim de se processar a pasteurização das tampas.

\subsection{5 - Resfriamento}

O resfriamento das latas, imediatamente após a recravação, foi feito por imersão das mesmas em tanque com circulação de água fria, até atingir a temperatura de $37^{\circ} \mathrm{C}$. 


\subsection{6 - Armazenamento}

Uma vez resfriadas, as latas foram armazenadas em prateleiras à temperatura ambiente.

\section{4 - Avaliação dos néctares comum e dietético}

Para avaliar a qualidade dos néctares comuns e dietéticos, assim como determinar qual variedade de morango melhor se adaptou ao processamento e também a eficiência dos tratamentos, foram realizadas análises físicas e químicas (aos 0, 30, 60, 90, 120, 150 e 180 dias de armazenamento) e sensorial (aos 30, 60 e 90 dias de armazenamento).

\subsection{1 - Análises físicas}

a) Vácuo: o vácuo das latas foi determinado com o auxílio de um vacuômetro "Marshaltown", em polegadas de mercúrio (pol.Hg).

b) Peso Bruto: foi utilizada uma balança semi-analítica (com precisão de $0,1 \mathrm{~g}$ ) para a determinação do peso total (embalagem + produto).

c) Peso Líqüido: foi determinado descontando-se do peso bruto, o peso da lata vazia, limpa e seca, utilizando balança semi-analítica (com precisão de $0,1 \mathrm{~g}$ ). 


\subsection{2. - Análises químicas}

a) Ácido ascórbico: determinado conforme já descrito no ítem 4.2.2.a

b) Acidez total titulável: determinada conforme já descrito no ítem 4.2.2.b

c) pH: determinado conforme já descrito no ítem 4.2.2.c

d) Sólidos solúveis totais: determinados conforme já descrito no ítem 4.2.2.d

Todas as determinações químicas realizadas no produto final foram efetuadas com duas repetições, em amostras tomadas aleatoriamente dos lotes dos produtos processados das duas variedades em estudo.

\subsection{3 - Análise sensorial}

As amostras dos néctares (comuns e dietéticos) das duas variedades foram avaliadas subjetivamente, após 30, 60 e 90 dias de armazenamento, quanto à cor, sabor e consistência. As avaliações das amostras foram realizadas por uma equipe de 8 provadores, previamente selecionados e treinados para este tipo de avaliação, utilizando uma escala numérica estruturada de nove pontos (Dawson, 1964; Girardot et al., 1952 e Martin, 1973). A seleção inicial dos provadores foi realizada com um número de 50 participantes, utilizando-se a sacarose no teste de diluição, determinando-se assim, os limites de deteção e identificação para o gosto doce, sendo então, 
selecionados os provadores mais sensiveis. A seleção final destes foi feita com os néctares comum e dietético de morango, através do teste triangular. Os modelos de fichas utilizados nestas avaliações estão apresentados nas Figuras 5,6 e 7 .

Para a avaliação da cor dos néctares, as amostras, devidamente codificadas, foram colocadas em placas de petri, as quais foram dispostas aleatoriamente em bandeja de plástico branco, colocada em local com iluminação de luz fluorescente.

Para a avaliação da consistência e sabor do produto, os néctares foram servidos em copos de plástico branco $(50 \mathrm{ml})$, codificados com números aleatórios de três dígitos e colocados em cabines individuais iluminadas com luz vermelha, a fim de mascarar a cor dos produtos.

\section{AVALIAÇÃO SENSORIAL}

Produto:

Nome do provador:

Data I...............

Por favor, analise as amostras e indique a intensidade da Cor, de acordo com a escala abaixo:

\begin{tabular}{|l|c|cc|ccc|cc|c|l|}
\hline \multirow{2}{*}{ Amostras } & Péssima & \multicolumn{2}{|c|}{ Ruim } & \multicolumn{2}{|c|}{ Regular } & \multicolumn{2}{|c|}{ Boa } & Ótima & Observações \\
& 1 & 2 & 3 & 4 & 5 & 6 & 7 & 8 & 9 & \\
\hline & & & & & & & \\
\hline & & & & & & & \\
\hline & & & & & & & \\
\hline & & & & & & & \\
\hline
\end{tabular}

Figura 5. Modelo de ficha utilizado na avaliação sensorial das amostras de néctar quanto à cor. 
AVALIAÇÃO SENSORIAL

Produto:

Nome do provador:

Data

...............

Por favor, prove as amostras e indique a intensidade da Consistência, de acordo com a escala abaixo:

\begin{tabular}{|c|c|cc|ccc|cc|c|l|}
\hline \multirow{2}{*}{ Amostras } & Péssima & \multicolumn{2}{|c|}{ Ruim } & \multicolumn{2}{|c|}{ Regular } & \multicolumn{2}{|c|}{ Boa } & Ótima & Observações \\
& 1 & 2 & 3 & 4 & 5 & 6 & 7 & 8 & 9 & \\
\hline & & & & & & & \\
\hline & & & & & & & & \\
\hline & & & & & & & \\
\hline
\end{tabular}

Figura 6 - Modelo de ficha utilizado na avaliação sensorial das amostras do néctar quanto à consistência.

Por favor, prove as amostras e indique a intensidade do Sabor, de acordo com a escala abaixo:

\begin{tabular}{|l|c|cc|ccc|cc|c|l|}
\hline \multirow{2}{*}{ Amostras } & $\begin{array}{c}\text { Péssimo } \\
1\end{array}$ & 2 & \multicolumn{2}{|l|}{ Ruim } & \multicolumn{2}{|l|}{ Regular } & \multicolumn{2}{|c|}{ Bom } & Ótimo & Observações \\
\hline & & & 4 & 5 & 6 & 7 & 8 & 9 & \\
\hline & & & & & & & & & \\
\hline & & & & & & & \\
\hline & & & & & & & \\
\hline
\end{tabular}

Figura 7 - Modelo de ficha utilizado na avaliação sensorial das amostras do néctar quanto ao Sabor. 
A análise sensorial foi efetuada sempre duas horas antes ou após as refeições, períodos estes mais adequados para realização do teste. As avaliações foram feitas com duas repetições, de forma que cada provador avaliasse a mesma amostra duas vezes (em sessões diferentes).

\subsection{4 - Análises estatísticas}

\section{a) Matéria-prima}

Os resultados da matéria-prima foram apresentados através de médias com seus respectivos erros-padrão, correspondente às duas repetições.

\section{b) Néctares comum e dietético}

Os dados dos néctares foram estatisticamente analisados através do delineamento em blocos casualizados com quatro tratamentos (três para o néctar dietético da variedade Guarani) e duas repetições para cada variedade, com a utilização do teste de Tukey ao nível de $5 \%$ de significância (Moraes, 1985 e Shirose, 1985).

As médias obtidas na avaliação sensorial foram analisadas por meio de delineamento em blocos casualizados com quatro tratamentos (três para o néctar dietético da variedade Guarani) e oito repetições para cada produto testado, com utilização do teste de Tukey ao nivel de $5 \%$ de significância. Cada provador foi designado como sendo um bloco. 


\section{RESULTADOS E DISCUSSÃO}

\subsection{Caracterização da matéria-prima}

\subsubsection{Análises físicas}

Na Tabela 1, são apresentados os resultados da avaliação objetiva dos atributos físicos da matéria-prima (textura, suculência e rendimento).

Tabela 1 - Características físicas dos morangos in natura (matéria-prima)

\section{MÉDIAS DAS ANÁLISES}

\begin{tabular}{lcc}
\hline \multicolumn{1}{c}{ Caracteristicas } \\
\multicolumn{1}{c}{ Fisicas } & Guarani & Oso Grande \\
Textura $(\mathrm{lbf} / \mathrm{g})$ & $0,84 \pm 0,024$ & $0,93 \pm 0,076$ \\
Suculência $(\mathrm{ml} / \mathrm{g})$ & $0,50 \pm 0,007$ & $0,50 \pm 0,007$ \\
Rendimento $(\%)$ & 94,0 & 93,5 \\
\hline
\end{tabular}

Segundo Chitarra \& Chitarra (1990), a textura é definida como "o conjunto de propriedades do alimento, compostas por características físicas perceptiveis pelo tato e que se relacionam com a deformação, desintegração e fluxo do alimento, sob a aplicação de uma força". As sensações que caracterizam a textura de frutos e hortaliças são múltiplas, na sua maioria induzidas por características mecânicas, embora também possam ser induzidas por características geométricas ou químicas. As principais sensações são de 
dureza, maciez, fibrosidade, suculência, granulosidade, qualidade farinácea, resistência e elasticidade. Em frutos, a textura é caracterizada pela maciez.

A variedade Guarani apresentou menor textura $(0,84)$ quando comparada com a variedade Oso Grande $(0,93)$, sendo que a suculência foi igual $(0,50)$ para ambas as variedades. Os valores da textura das variedades de morango Reiko e Chandler, estudadas por Richards (1996), foram de 0,58 e 0,89 respectivamente, e segundo Berbari et al. (1994), de 0,64 para IACPrincesa Isabel e 0,61lbf/g para a variedade Sequóia.

Chitarra \& Chitarra (1990) afirmam que frutos e hortaliças destinados ao processamento, devem ser firmes o suficiente para suportarem os tratamentos térmicos, estando a firmeza diretamente correlacionada ao conteúdo e tipo de pectina presentes. As substâncias pécticas são os principais componentes químicos dos tecidos, responsáveis pelas mudanças de textura dos frutos e hortaliças.

Segundo Hudson et al. (1975), a suculência é um atributo físico dos frutos frescos inversamente proporcional à textura destes, isto é, quanto mais firme, menos suculento ele será. Apesar da variedade Guarani ter apresentado uma textura menor $(0,84)$ em relação à Oso Grande $(0,93)$, as duas variedades apresentaram o mesmo valor de suculência $(0,50)$. Este fato pode estar relacionado ao rendimento dos frutos, que foi praticamente igual para as duas variedades.

O rendimento é um parâmetro de qualidade para a indústria de concentrados (purês, doces em massa, néctares, sucos, etc.), já que reflete quantitativamente, a qualidade da matéria-prima. As porcentagens de rendimento das duas variedades estudadas também não diferiram muito entre 
si já, que para cada $1.000 \mathrm{~g}$ de morango in natura, $940 \mathrm{~g}$ da Guarani e $935 \mathrm{~g}$ da Oso Grande foram utilizados para o processamento, o que representa um alto aproveitamento e boa qualidade da matéria-prima, praticamente com ausência de frutos amassados, machucados ou deteriorados por microrganismos.

\subsubsection{Análises químicas}

Na Tabela 2, são apresentados os resultados das determinações do teor de ácido ascórbico, pH, acidez total titulável e do teor de sólidos solúveis totais da matéria-prima.

Tabela 2 - Características químicas dos morangos in natura (matéria-prima)

\section{MÉDIAS DAS ANÁLISES}

Características

Químicas
Guarani

\section{Variedades}

\begin{tabular}{llr}
\multicolumn{1}{c}{ Químicas } & Guarani & Oso Grande \\
\hline ácido ascórbico $(\mathrm{mg} / 100 \mathrm{~g})$ & $70,71 \pm 1,010$ & $69,04 \pm 3,600$ \\
pH & $3,46 \pm 0,034$ & $3,81 \pm 0,015$ \\
acidez total titulável (\%) & $0,81 \pm 0,060$ & $0,67 \pm 0,100$ \\
sólidos solúveis totais ( ${ }^{\circ}$ Brix) & $5,26 \pm 0,500$ & $8,62 \pm 0,500$ \\
\hline
\end{tabular}

Comparando os valores do teor de ácido ascórbico das variedades Guarani e Oso Grande, verifica-se que os mesmos são semelhantes $(70,71$ e 69,04 respectivamente). Estes resultados estão de acordo com os obtidos em frutas frescas, que variam de 50 a 90mg/100g (Eskin, 1991), porém, representam teores menores em relação ao valor médio de $77 \mathrm{mg} / 100 \mathrm{~g}$, relatado por Mc Cance \& Widdowson's (1994) e de 78,75 encontrado por Novaes (1993) para a variedade Lassen. Já, comparando-se com as variedades estudadas por Paschoalino et al. (1973/74), cujo intervalo de 
valores variou entre 24 e $64 \mathrm{mg} / 100 \mathrm{~g}$, observa-se que as variedades do presente trabalho apresentaram maiores teores de ácido ascórbico. É bom ressaltar que os teores deste componente variam grandemente com fatores como variedades e condições de cultivo (Eskin, 1991).

A acidez das variedades em estudo foi analisada em termos de valores de $\mathrm{pH}$ e acidez total titulável ( $\mathrm{g}$ ácido cítrico/100g de fruto). De acordo com Chitarra \& Chitarra (1990), os ácidos orgânicos encontram-se dissolvidos nos vacúolos das células, tanto na forma livre, como combinada com sais, ésteres, glicosídeos, etc. Em frutos, não só contribuem para a acidez, como também para o aroma característico, porque alguns componentes são voláteis.

O teor de ácidos orgânicos diminui com a maturação, em decorrência do processo respiratório ou de sua conversão em açúcares. Os compostos ácidos são numerosos e possuem natureza química variada. Dentre eles, os mais abundantes em frutos são o cítrico e o málico, havendo predominância desses ou de outros, de acordo com a espécie. No caso do morango, a acidez é expressa em gramas de ácido cítrico/100g do fruto.

$\mathrm{O}$ valor médio de $\mathrm{pH}$ (Tabela 2) obtido para a variedade Guarani $(3,46)$ foi intermédiário aos apresentados pelas variedades IAC-Princesa Isabel $(3,71)$, Reiko $(3,62)$, Sequóia $(3,36)$ e Chandler $(3,39)$ (Berbari et al., 1994).

A variedade Guarani apresentou valor médio de acidez total titulável (0,81 $\mathrm{mg}$ de ácido cítrico/100g do fruto) próximo ao da variedade Reiko $(0,83)$, estudada por Richards (1996) e intermediário aos das variedades analisadas por Berbari et al. (1994), (que variaram de 0,73 a 1,00). Comparando-se os valores de $\mathrm{pH}$ e acidez total titulável (Tabela 2 ), pode-se dizer que a variedade Oso Grande apresenta menor acidez do que a Guarani, já que aquela 
apresentou valor médio de acidez total titulável $(0,67)$ menor do que o da outra variedade $(0,81)$, bem como maior valor de $\mathrm{pH}(3,81)$ quando comparado com o da Guarani $(3,46)$.

Os sólidos solúveis totais (Tabela 2) indicam a quantidade, em gramas, de sólidos que se encontram dissolvidos no produto. São comumente designados em ${ }^{\circ}$ Brix e, no caso dos frutos, têm tendência de aumento com a maturação, através de processos de biossíntese ou pela degradação de polissacarídeos. Este parâmetro químico representa uma das melhores formas de avaliação do grau de doçura do produto, já que o teor de açúcares normalmente constitui 65 a $85 \%$ do teor de sólidos solúveis totais (Chitarra \& Chitarra, 1990).

A Tabela 2 mostra que a variedade Guarani apresentou menor teor de sólidos solúveis $\left(5,26^{\circ} \mathrm{Brix}\right)$ do que a variedade Oso Grande $\left(8,62^{\circ} \mathrm{Brix}\right)$ que, por sua vez, possui valor médio intermediário aos encontrados nas variedades estudadas por Berbari et al. (1994), que variaram de 6,6 a $8,7^{\circ} \mathrm{Brix}$, e valor médio inferior ao da variedade Lassen ( $\left.9^{\circ} \mathrm{Brix}\right)$, analisada por Novaes (1993).

\section{2 - Caracterização do néctar comum}

\subsection{1 - Análises físicas}

Os valores médios de vácuo das latas dos néctares, para ambas variedades (Tabela 3) não apresentaram diferenças significativas em relação aos tratamentos, bem como em função do tempo de armazenamento.

Estes valores estão dentro da faixa de vácuo normal numa lata de fruta em calda, que deve ser entre 8 e 15 pol. de $\mathrm{Hg}$. De acordo com Martin 
(1965/66), o vácuo é dependente das operações de exaustão e da temperatura do produto na operação de fechamento das latas. Assim sendo, pode-se dizer que a operação de recravação das latas foi feita de maneira adequada, evitando-se o efeito prejudicial das reações oxidativas, as quais resultam na deterioração do ácido ascórbico, escurecimento e alterações organolépticas do néctar.

O oxigênio dissolvido em sucos é rapidamente exaurido, unindo-se ao ácido ascórbico, ou é removido pelo tratamento térmico de pasteurização. Como consequência, o potencial redox dos sucos é baixo; no entanto, a embalagem constituída de materiais mais ou menos permeáveis, ou embalagens que permitam um grande espaço livre, pode aumentar significativamente o teor de oxigênio dissolvido e o potencial redox, exercendo uma influência significativa sobre o produto (Uboldi Eiroa, 1989).

Tabela 3 - Valores médios do vácuo (pol. $\mathrm{Hg}$ ) das latas dos néctares comuns de morango, em função do tempo de armazenamento

\begin{tabular}{|c|c|c|c|c|c|c|c|c|c|c|}
\hline \multirow[b]{3}{*}{ Tempo(dias) } & \multicolumn{10}{|c|}{ VARIEDADES } \\
\hline & \multicolumn{4}{|c|}{ GUARANI } & \multicolumn{6}{|c|}{ OSO GRANDE } \\
\hline & T1 & T2 & T3 & T4 & MÉDIAS & T1 & T2 & T3 & T4 & MÉDIAS \\
\hline 0 & 11,50 & 11,50 & 11,25 & 12,75 & $11,75^{A}$ & 11,50 & 13,25 & 11,250 & 12,00 & $12,00^{A}$ \\
\hline 30 & 12,50 & 10,50 & 11,75 & 13,00 & $11,94^{\mathrm{A}}$ & 12,00 & 11,00 & 11,250 & 12,75 & $11,75^{A}$ \\
\hline 60 & 10,75 & 10,25 & 9,75 & 10,50 & $10,31^{A}$ & 11,75 & 11,25 & 10,50 & 11,50 & $11,25^{A}$ \\
\hline 90 & 10,75 & 12,50 & 12,00 & 12,00 & $11,81^{A}$ & 10,75 & 11,00 & 12,50 & 11,50 & $11,44^{A}$ \\
\hline 120 & 13,25 & 11,25 & 12,25 & 11,75 & $12,12^{A}$ & 12,25 & 10,75 & 10,75 & 10,75 & $11,43^{A}$ \\
\hline 150 & 10,50 & 11,00 & 11,75 & 13,25 & $11,63^{A}$ & 10,75 & 11,50 & 11,00 & 10,75 & $11,00^{A}$ \\
\hline 180 & 11,00 & 11,50 & 10,75 & 11,75 & $11,25^{A}$ & 11,25 & 11,00 & 11,25 & 12,25 & $11,44^{A}$ \\
\hline MÉDIAS & $11,46^{A}$ & $11,21^{A}$ & $11,36^{A}$ & $12,14^{A}$ & - & $11,46^{A}$ & $11,39^{A}$ & $11,24^{A}$ & $11,64^{A}$ & - \\
\hline F(TRAT.) & & $2,00^{\text {n.s. }}$ & & & - & & $0,43^{\text {n.s. }}$ & & & - \\
\hline F(TEMPO) & & $2,17^{\text {n.S. }}$ & & & - & & $2,02^{\text {n.s. }}$ & & & - \\
\hline
\end{tabular}

T1, T2, T3 e T4 = tratamentos

n.s. = não significativo

médias com a mesma letra não diferem entre si ao nível de $5 \%$ de significância 
Muitas vezes, o oxigênio dissolvido no produto elou presente no espaço-livre, já é suficiente para desencadear as reações de oxidação, não bastando apenas a barreira da embalagem ao oxigênio. Logo, a desaeração do produto antes do acondicionamento e o emprego de técnicas que reduzam o espaço-livre ou que diminuam a concentração de oxigênio no espaço-livre irão contribuir decididamente para aumentar a vida útil dos sucos de frutas (Alves \& Garcia, 1991).

Os pesos médios (bruto e líqüido) das latas dos néctares das duas variedades (Tabelas 4 e 5) também não apresentaram diferenças estatísticas significativas entre os diferentes tratamentos e ao longo do período de armazenamento. Estas análises mostraram que o preenchimento das latas foi feito de maneira adequada, obtendo-se assim, produtos com pesos semelhantes, fato este altamente desejável em qualquer tipo de processamento de alimentos, já que o peso é um dos importantes fatores no controle de qualidade.

Tabela 4 - Valores médios do peso bruto $(\mathrm{g})$ das latas dos néctares comuns de morango, em função do tempo de armazenamento

\section{VARIEDADES}

GUARANI

OSO GRANDE

\begin{tabular}{c|cccc|c|cccc|c}
\hline Tempo(dias) & T1 & T2 & T3 & T4 & MÉDIAS & T1 & T2 & T3 & T4 & MEDIAS \\
\hline 0 & 391,9 & 410,7 & 406,3 & 407,7 & $404,2^{\mathrm{A}}$ & 408,9 & 408,3 & 408,0 & 409,1 & $408,6^{\mathrm{A}}$ \\
30 & 399,7 & 395,5 & 408,6 & 396,7 & $400,1^{\mathrm{A}}$ & 406,6 & 408,4 & 408,6 & 407,5 & $407,8^{\mathrm{A}}$ \\
60 & 400,2 & 395,8 & 405,4 & 396,8 & $400,3^{\mathrm{A}}$ & 406,7 & 408,8 & 407,4 & 407,9 & $407,7^{\mathrm{A}}$ \\
90 & 401,7 & 708,1 & 407,8 & 407,7 & $406,3^{\mathrm{A}}$ & 407,1 & 408,2 & 408,3 & 408,3 & $407,9^{\mathrm{A}}$ \\
120 & 405,7 & 409,3 & 403,1 & 408,0 & $406,5^{\mathrm{A}}$ & 408,1 & 408,7 & 408,3 & 408,8 & $408,5^{\mathrm{A}}$ \\
150 & 396,2 & 402,2 & 401,8 & 400,1 & $400,1^{\mathrm{A}}$ & 407,7 & 407,8 & 408,2 & 408,3 & $408,0^{\mathrm{A}}$ \\
180 & 404,6 & 408,9 & 406,7 & 401,1 & $407,4^{\mathrm{A}}$ & 409,3 & 408,7 & 406,4 & 407,9 & $408,6^{\mathrm{A}}$ \\
\hline MÉDIAS & $400,9^{\mathrm{A}}$ & $404,2^{\mathrm{A}}$ & $405,6^{\mathrm{A}}$ & $403,9^{\mathrm{A}}$ & - & $407,7^{\mathrm{A}}$ & $408,4^{\mathrm{A}}$ & $408,2^{\mathrm{A}}$ & $408,3^{\mathrm{A}}$ & - \\
\hline F(TRAT.) & \multicolumn{7}{c}{$1,35^{\text {n.S. }}$} \\
\hline F(TEMPO) & $2,35^{\text {n.S. }}$ \\
\hline
\end{tabular}

T1, T2, T3 e T4 = tratamentos n.s. = não significativo

médias com a mesma letra não diferem entre si ao nivel de $5 \%$ de significância 
Tabela 5 - Valores médios do peso líqüido $(\mathrm{g})$ das latas dos néctares comuns de morango, em função do tempo de armazenamento

\begin{tabular}{|c|c|c|c|c|c|c|c|c|c|c|}
\hline \multirow[b]{3}{*}{ Tempo(dias) } & \multicolumn{10}{|c|}{ VARIEDADES } \\
\hline & \multicolumn{4}{|c|}{ GUARANI } & \multicolumn{6}{|c|}{ OSO GRANDE } \\
\hline & T1 & T2 & T3 & T4 & MÉDIAS & T1 & T2 & T3 & T4 & MÉDIAS \\
\hline 0 & 334,2 & 354,0 & 349,6 & 348,5 & $346.6^{A}$ & 352,3 & 350,2 & 353,0 & 353,2 & $352,2^{A}$ \\
\hline 30 & 347,8 & 345,7 & 351,8 & 344,1 & $347,3^{A}$ & 349,7 & 350,7 & 353,4 & 350,6 & $351,1^{A}$ \\
\hline 60 & 345,2 & 347,5 & 355,7 & 348,5 & $349,2^{A}$ & 350,4 & 353,1 & 350,7 & 350,9 & $351,3^{A}$ \\
\hline 90 & 348,2 & 347,8 & 355,5 & 352,7 & $351,0^{A}$ & 351,7 & 355,1 & 354,6 & 350,6 & $353,0^{A}$ \\
\hline 120 & 349,9 & 352,8 & 346,8 & 353,2 & $350,7^{A}$ & 350,6 & 353,6 & 353,9 & 352,8 & $352,7^{A}$ \\
\hline 150 & 344,3 & 353,0 & 346,7 & 346,1 & $347,5^{\mathrm{A}}$ & 351,8 & 355,4 & 353,1 & 353,1 & $353,3^{A}$ \\
\hline 180 & 353,1 & 354,2 & 351,8 & 354,5 & $353,4^{A}$ & 354,7 & 353,8 & 348,6 & 352,1 & $352,3^{A}$ \\
\hline MÉDIAS & $346,1^{A}$ & $350,7^{A}$ & $351,1^{A}$ & $349,7^{A}$ & - & $351,6^{A}$ & $353,1^{A}$ & $352,5^{A}$ & $351,9^{A}$ & - \\
\hline F(TRAT.) & & $2,06^{\text {n.s. }}$ & & & - & & $1,02^{\text {n.s. }}$ & & & - \\
\hline$\overline{F(T E M P O)}$ & & $2,33^{\text {n.S. }}$ & & & - & & $0,79^{\text {n.s. }}$ & & & - \\
\hline
\end{tabular}

T1, T2, T3 e T4 = tratamentos

n.s. = não significativo

médias com a mesma letra não diferem entre si ao nível de $5 \%$ de significância

\subsection{2 - Análises químicas}

$\mathrm{Na}$ Tabela 6 encontram-se os valores médios de ácido ascórbico constatados nas amostras do néctar das variedades Guarani e Oso Grande. Pela observação dos resultados, verifica-se que as perdas desta vitamina, ao longo do período de armazenamento dos néctares de ambas variedades foram significativas ao nível de $1 \%$ e que os valores das médias dos tratamentos 1, 2 e 3 da variedade Guarani, não diferiram estatisticamente entre si, porém, como era de se esperar, diferiram do tratamento 4 , o qual recebeu adição de ácido ascórbico. Já, para a variedade Oso Grande, houve diferença significativa entre o tratamento testemunha (T1) e os tratamentos 3 e 4; este último foi estatisticamente diferente dos demais, pois recebeu adição de ácido ascórbico. 
Bleinroth et al. (1977) analisaram o teor de ácido ascórbico em néctar de abacaxi-laranja durante seis meses de armazenamento, também em temperatura ambiente, e os valores finais encontrados desta vitamina ficaram entre 4 e $6 \mathrm{mg} / 100 \mathrm{~g}$, dependendo da formulação utilizada, sendo que os valores iniciais de ácido ascórbico encontravam-se entre 8 e $10 \mathrm{mg} / 100 \mathrm{~g}$.

Berbari et al. (1994), Goldoni et al. (1981) e Richards (1996) também observaram perdas altamente significativas em morangos congelados, sucos de morango e morangos enlatados, respectivamente. Segundo estes autores, as perdas de ácido ascórbico aumentam com a elevação da temperatura, já que este ácido transforma-se em ácido dehidroascórbico.

Tabela 6 - Valores médios dos teores de ácido ascórbico $(\mathrm{mg} / 100 \mathrm{~g})$ dos néctares comuns de morango, em função do tempo de armazenamento

\section{VARIEDADES}

\begin{tabular}{|c|c|c|c|c|c|c|c|c|c|c|}
\hline & \multicolumn{4}{|c|}{ GUARANI } & \multicolumn{6}{|c|}{ OSO GRANDE } \\
\hline Tempo(dias) & T1 & T2 & T3 & T4 & MÉDIAS & T1 & T2 & T3 & T4 & MEDIAS \\
\hline 0 & 42,65 & 42,50 & 43,34 & 74,64 & $50,78^{A}$ & 41,00 & 41,25 & 41,25 & 71,43 & $48,73^{A}$ \\
\hline 30 & 40,60 & 40,62 & 41,75 & 71,43 & $48,60^{A B}$ & 38,25 & 38,80 & 41,10 & 66,08 & $46,06^{B}$ \\
\hline 60 & 38,65 & 36,58 & 39,65 & 67,38 & $45,57^{\mathrm{BC}}$ & 34,16 & 35,16 & 39,25 & 61,96 & $42,70^{C}$ \\
\hline 90 & 35,90 & 33,75 & 37,50 & 64,65 & $42,95^{C D}$ & 30,50 & 31,50 & 36,25 & 55,75 & $38,50^{\mathrm{D}}$ \\
\hline 120 & 27,00 & 31,71 & 33,67 & 62,50 & $38,72^{\mathrm{DE}}$ & 24,45 & 29,35 & 33,68 & 53,03 & $35,32^{E}$ \\
\hline 150 & 24,75 & 31,60 & 32,50 & 57,50 & $36,59^{\mathrm{EF}}$ & 22,75 & 27,50 & 31,00 & 52,50 & $33,44^{E}$ \\
\hline 180 & 24,40 & 24,32 & 29,73 & 53,58 & $33,01^{F}$ & 21,06 & 24,33 & 27,15 & 48,77 & $30,42^{F}$ \\
\hline MEDIAS & $33,42^{B}$ & $34,44^{B}$ & $36,87^{B}$ & $64,53^{A}$ & - & $30,38^{C}$ & $32,59^{B C}$ & $35,76^{B}$ & $58,50^{A}$ & - \\
\hline F(TRAT.) & & $453,17^{\star \star}$ & & & _ & & $227,52^{* \star}$ & & & - \\
\hline (TEMPO) & & $46,10^{* \star}$ & & & - & & $160,58^{* \star}$ & & & \\
\hline
\end{tabular}

$\mathrm{T} 1, \mathrm{~T} 2, \mathrm{~T} 3$ e $\mathrm{T} 4=$ tratamentos

** $=$ significativo ao nível de $1 \%$

médias com a mesma letra não diferem entre si ao nível de $5 \%$ de significância 
É possivel observar, pelas Figuras 8 e 9, a diminuição do teor de ácido ascórbico, em função do tempo de armazenamento dos néctares das duas variedades em estudo, e pela análise das Tabelas 2 e 6, conclui-se que durante $o$ processamento da matéria-prima e armazenamento dos néctares (T1, T2 e T3), as perdas em média foram de $50,62 \%$ e $52,33 \%$ para as variedades Guarani e Oso Grande, respectivamente.

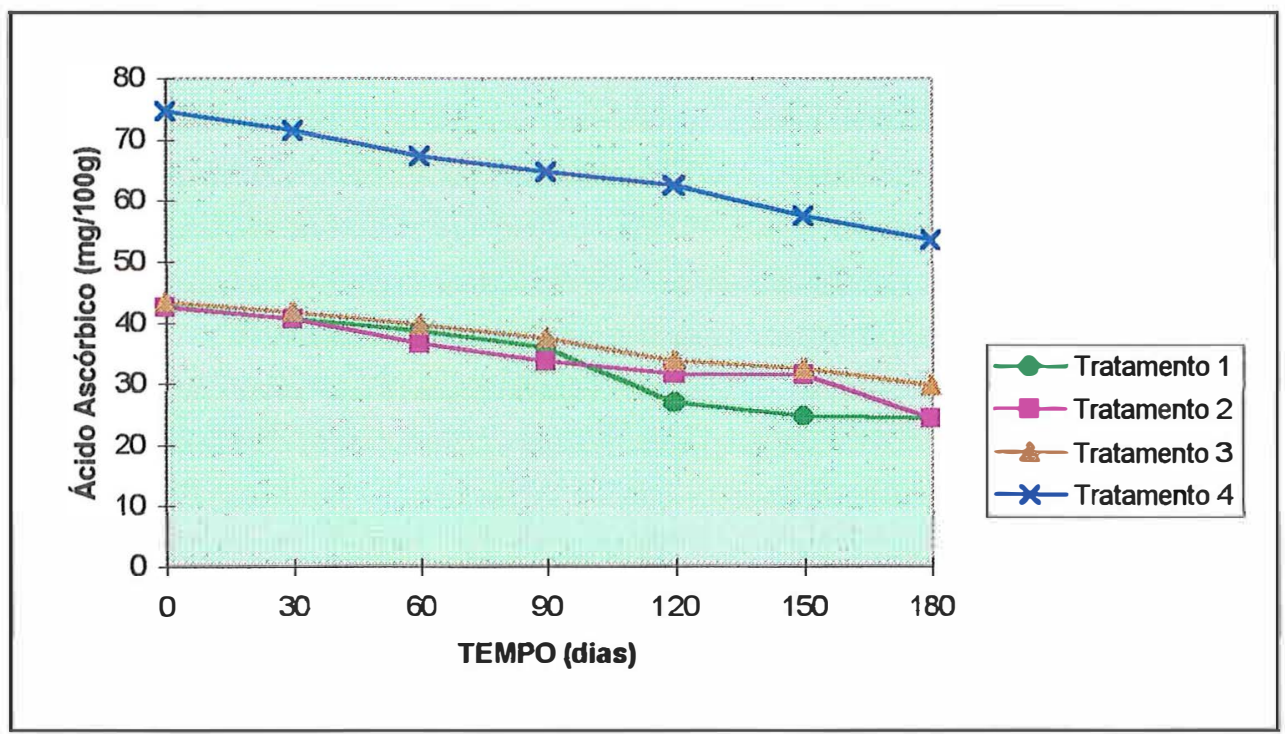

Figura 8 -Teores de ácido ascórbico dos néctares comuns de morango da variedade Guarani, em função do tempo de armazenamento

Mesmo após seis meses de armazenamento, os néctares que não receberam adição de ácido ascórbico (T1, T2 e T3), apresentaram razoáveis teores desta vitamina (ao redor de $25 \mathrm{mg} / 100 \mathrm{~g}$ ). O tratamento que recebeu adição de ácido ascórbico (T4) permitiu que os néctares das duas variedades, após 180 dias de armazenamento, apresentassem um teor médio final bem mais elevado (ao redor de $50 \mathrm{mg} / 100 \mathrm{~g}$ ) em relação aos outros tratamentos, enriquecendo assim o produto. Comparando-se o teor de ácido ascórbico, entre os néctares das duas variedades (Figura 10), observa-se que os da 
Guarani apresentaram maiores teores da vitamina ao longo do período de armazenamento.

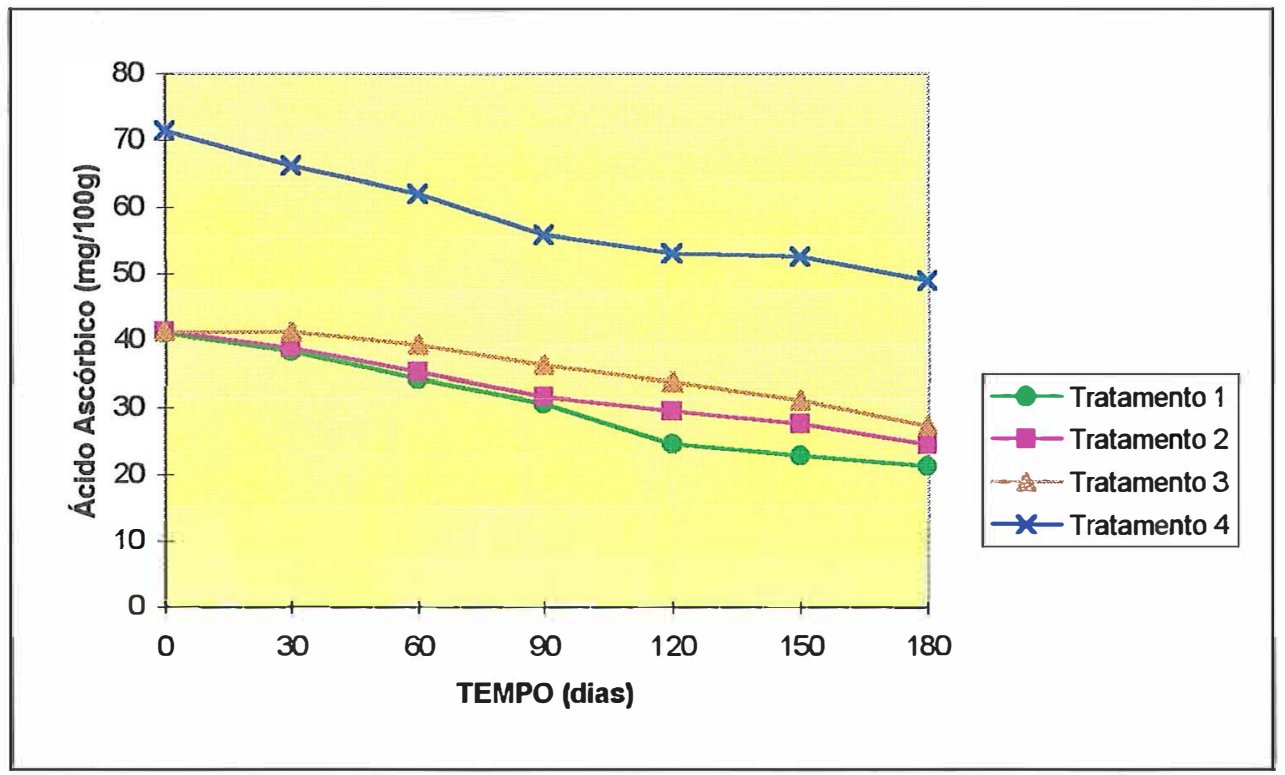

Figura 9 - Teores de ácido ascórbico dos néctares comuns de morango da variedade Oso Grande, em função do tempo de armazenamento

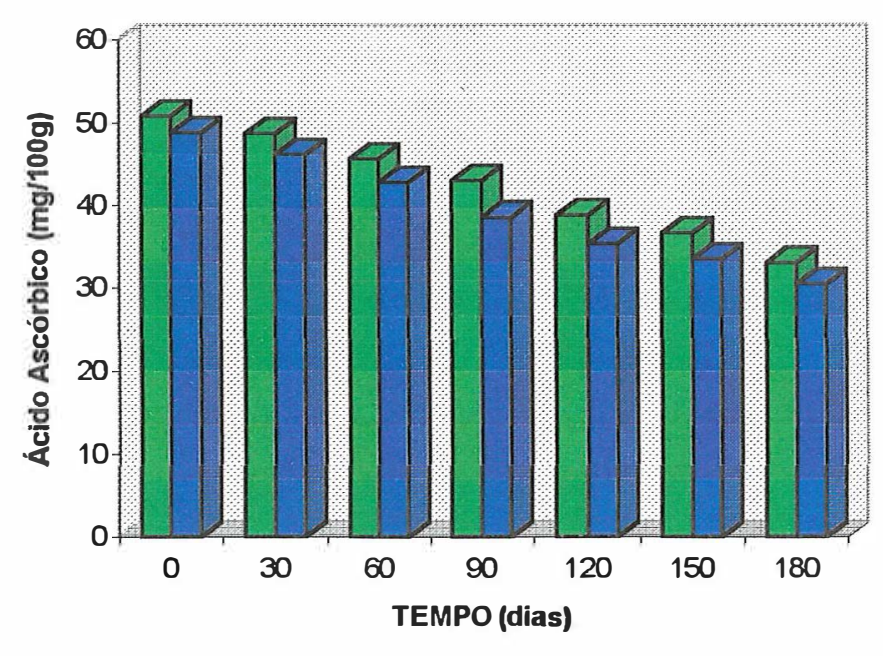

GGUARANI DOSO GRANDE

Figura 10 - Teores de ácido ascórbico dos néctares comuns de morango, em função do tempo de armazenamento 
Os valores médios de acidez total titulável dos néctares das duas variedades de morango (Tabela 7) diminuiram significativamente ao longo do tempo de armazenamento e apresentaram diferenças significativas entre os tratamentos (Tabela 7 e Figuras 11 e 12), apresentando a variedade Guarani, néctares com valores médios de acidez maiores em todo o período (Figura13). A redução da acidez total titulável das duas variedades, foi provavelmente acompanhada pela diminuição no teor de ácido ascórbico, já que este é um dos componentes da acidez total titulável. Observa-se também pela Tabela 7 que o tratamento 4, para o néctar da variedade Oso Grande, diferiu estatisticamente dos demais tratamentos, já que neste, houve adição de ácido ascórbico e, conseqüentemente, um aumento no teor de acidez.

Tabela 7 - Valores médios de acidez total titulável (g ácido cítrico/100g) dos néctares comuns de morango, em função do tempo de armazenamento

VARIEDADES

GUARANI

OSO GRANDE

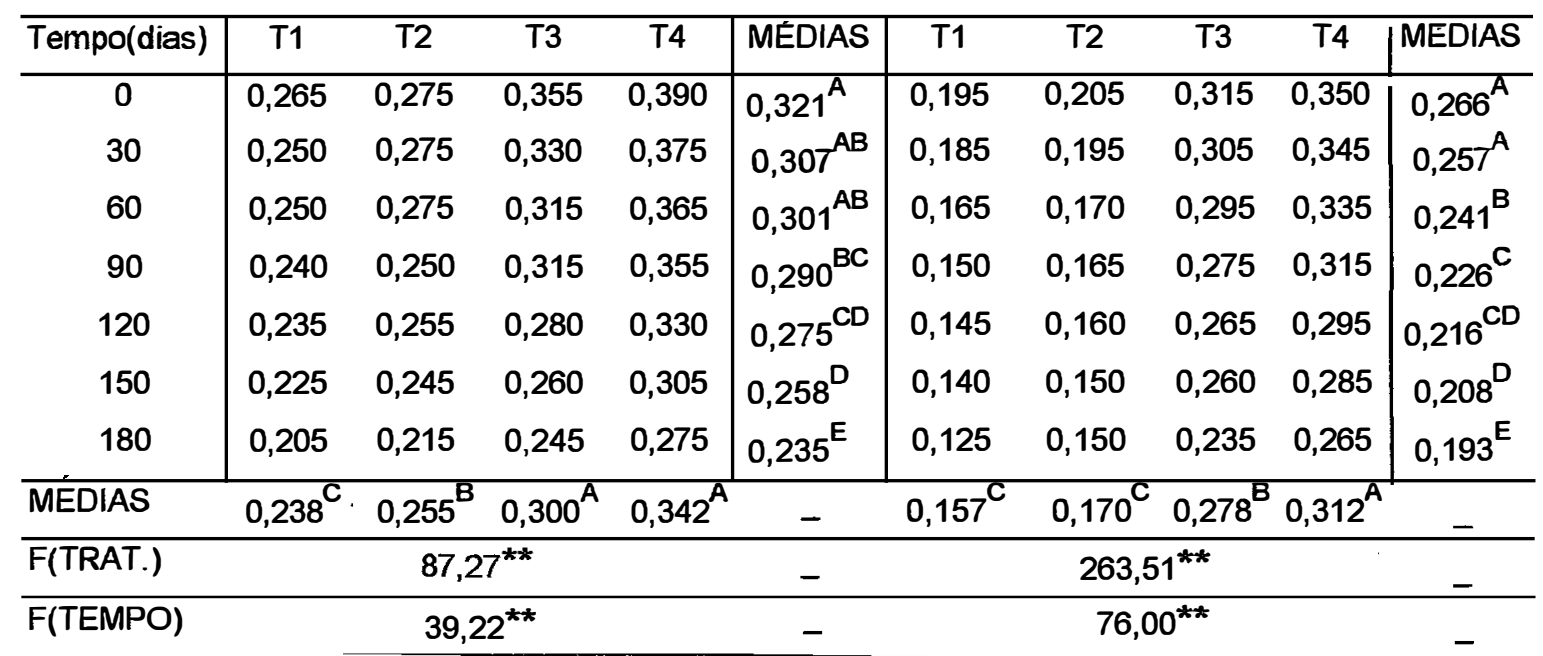

$\mathrm{T} 1, \mathrm{~T} 2, \mathrm{~T} 3$ e $\mathrm{T} 4=$ tratamentos

${ }^{* *}=$ significativo ao nível de $1 \%$

médias com a mesma letra não diferem entre si ao nível de $5 \%$ de significância 


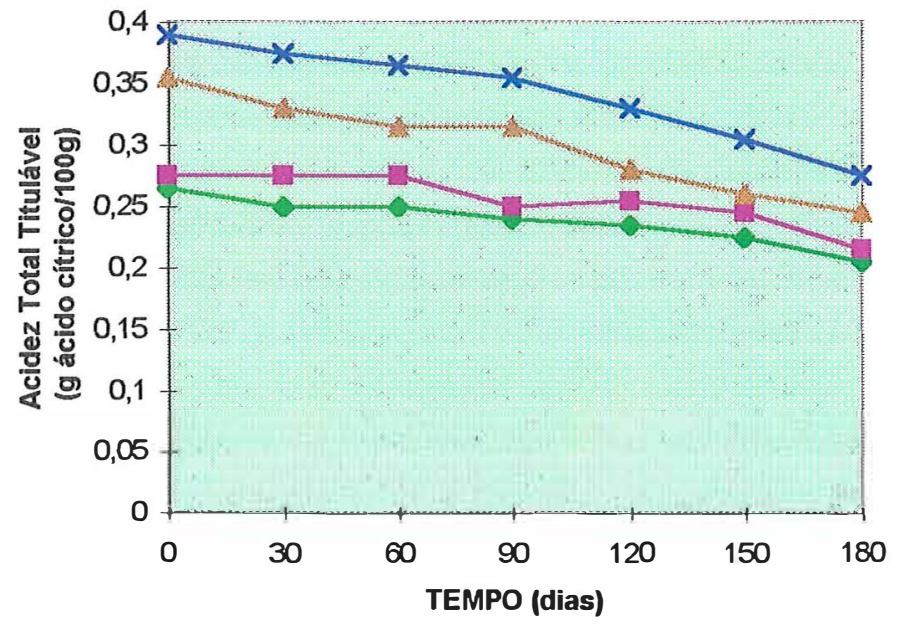

- Tratamento 1

- Tratamento 2

-..n- Tratamento 3

$x$ Tratamento 4

Figura 11 - Teores de acidez total titulável em néctares comuns de morango da variedade Guarani, em função do tempo de armazenamento
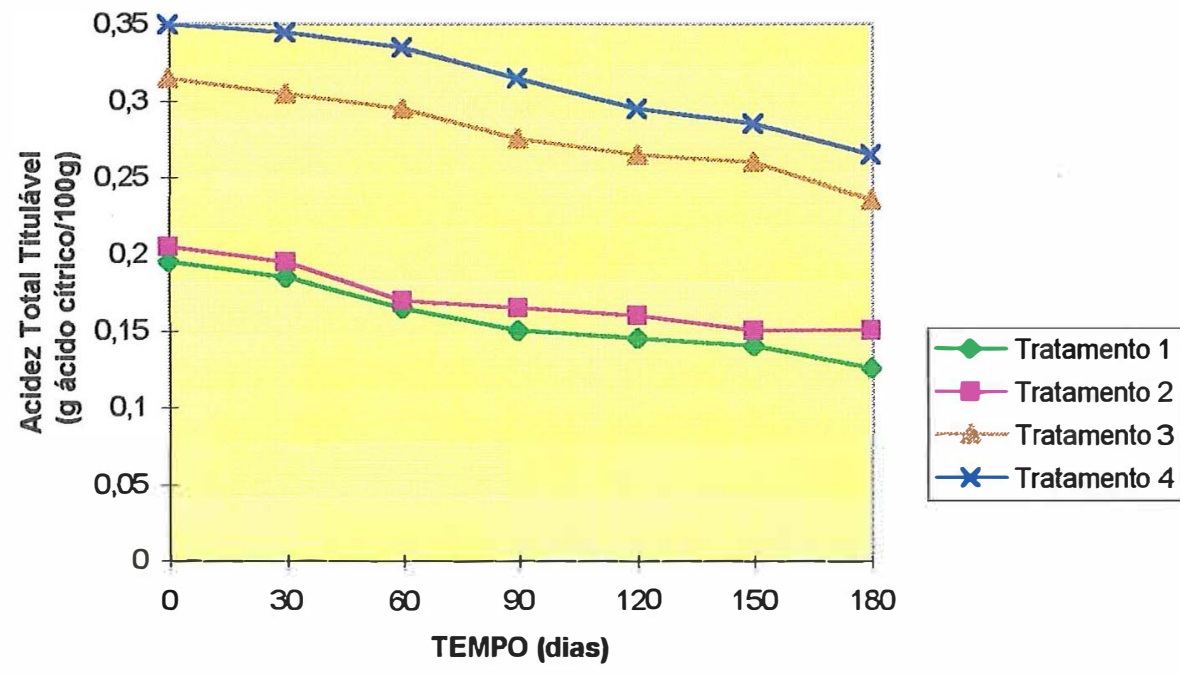

Figura 12 - Teores de acidez total titulável em néctares comuns de morango da variedade Oso Grande, em função do tempo de armazenamento 
Para o néctar da Guarani (Tabela 7), o tratamento 4 diferiu apenas dos tratamentos 1 e 2. As médias de acidez dos néctares da variedade Guarani foram maiores do que as da variedade Oso Grande, mostrando que a matériaprima com maior acidez, no caso a variedade Guarani, caracterizou um produto final também mais ácido em relação ao da variedade Oso Grande.

Salomón et al. (1977) não observaram variação significativa de acidez total titulável em néctares de mamão-maracujá até seis meses de armazenamento, sendo os valores médios $(0,50 \mathrm{~g}$ ácido cítrico/100g) superiores aos do néctar do presente trabalho. Aradhita et al. (1995) analisaram quimicamente néctares de goiaba, e os resultados mostraram um aumento linear nos valores de acidez total titulável ao longo do período de armazenamento. Gofur et al. (1994) conservaram néctar de manga utilizando vários tipos de formulações e não observaram diferenças significativas em relação à acidez total titulável, em função do tempo de estocagem do néctar.

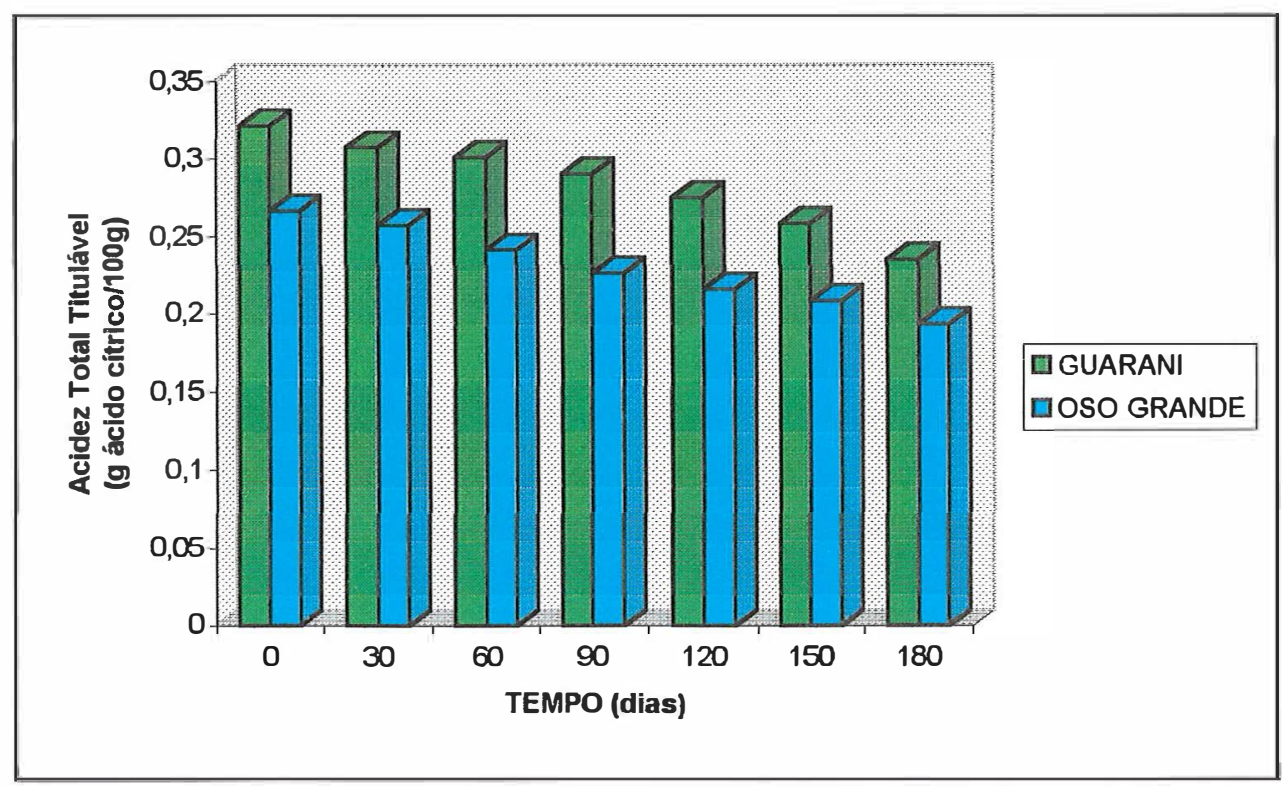

Figura 13 -Teores de acidez total titulável em néctares comuns de morango, em função do tempo de armazenamento 
Pela análise da Tabela 8 , observa-se que os valores médios de $\mathrm{pH}$ dos néctares das duas variedades em questão, não variaram estatisticamente em função do período de armazenamento. Entretanto, houve diferença significativa entre os quatro tratamentos do néctar da variedade Guarani, enquanto os tratamentos 3 e 4 da variedade Oso Grande diferiram tanto entre si como dos tratamentos 1 e 2 . Esta variação do $\mathrm{pH}$ do néctar de morango em função dos diferentes tratamentos aplicados, para ambas variedades, pode ser visualizada pelas Figuras 14, 15 e 16.

Tabela 8 - Valores médios de $\mathrm{pH}$ dos néctares comuns de morango, em função do tempo de armazenamento

\begin{tabular}{|c|c|c|c|c|c|c|c|c|c|c|}
\hline \multirow[b]{3}{*}{$\overline{T e m p o(d i a s)}$} & \multicolumn{10}{|c|}{ VARIEDADES } \\
\hline & \multicolumn{4}{|c|}{ GUARANI } & \multicolumn{6}{|c|}{ OSO GRANDE } \\
\hline & T1 & T2 & T3 & T4 & MÉDIAS & T1 & T2 & T3 & T4 & MÉDIAS \\
\hline 0 & 3,46 & 3,52 & 3,35 & 3,32 & $3,43^{A}$ & 3,75 & 3,80 & 3,32 & 3,30 & $3,59^{A}$ \\
\hline 30 & 3,46 & 3,54 & 3,39 & 3,30 & $3,42^{\mathrm{A}}$ & 3,75 & 3,77 & 3,33 & 3,31 & $3,56^{A}$ \\
\hline 60 & 3,48 & 3,53 & 3,36 & 3,30 & $3,42^{A}$ & 3,77 & 3,79 & 3,32 & 3,31 & $3,55^{A}$ \\
\hline 90 & 3,44 & 3,54 & 3,38 & 3,31 & $3,42^{A}$ & 3,76 & 3,79 & 3,35 & 3,31 & $3,55^{A}$ \\
\hline 120 & 3,46 & 3,54 & 3,40 & 3,33 & $3,41^{A}$ & 3,77 & 3,76 & 3,33 & 3,30 & $3,55^{A}$ \\
\hline 150 & 3,44 & 3,54 & 3,37 & 3,29 & $3,41^{A}$ & 3,77 & 3,78 & 3,38 & 3,29 & $3,55^{A}$ \\
\hline 180 & 3,46 & 3,52 & 3,36 & 3,30 & $3,41^{A}$ & 3,76 & 3,80 & 3,36 & 3,30 & $3,54^{A}$ \\
\hline MÉDIAS & $3,46^{\mathrm{B}}$ & $3,54^{A}$ & $3,37^{\mathrm{C}}$ & $3,31^{D}$ & \multicolumn{2}{|r|}{$3,77^{A}$} & $3,78^{A}$ & $3,34^{B}$ & $3,31^{C}$ & - \\
\hline \multicolumn{2}{|l|}{$\overline{\text { F(TRAT.) }}$} & \multicolumn{2}{|c|}{$363,87^{\star *}$} & & - & & \multicolumn{2}{|c|}{$26,63^{* *}$} & & - \\
\hline \multicolumn{2}{|l|}{$\overline{F(T E M P O)}$} & \multicolumn{2}{|c|}{$1,37^{\text {n.S. }}$} & & - & & \multicolumn{2}{|c|}{$1,04^{\text {n.s }}$} & & - \\
\hline
\end{tabular}

T1, T2, T3 e T4 = tratamentos

n.s.= não significativo

** = significativo ao nivel de $1 \%$

médias com a mesma letra não diferem entre si ao nivel de $5 \%$ de significância

Goldoni et al. (1981) também observaram que os valores de $\mathrm{pH}$ em suco pasteurizado de morango, permaneceram praticamente estáveis ao longo do período de armazenamento. 


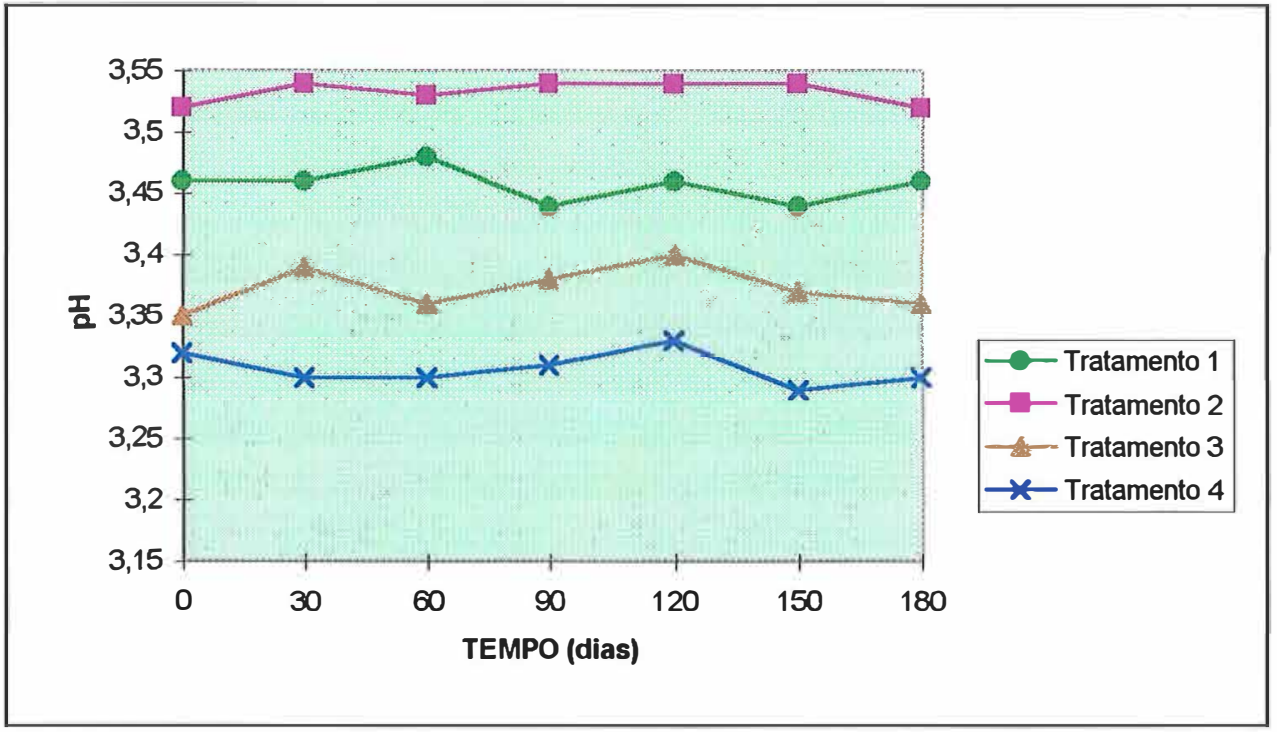

Figura 14 - Valores de $\mathrm{pH}$ dos néctares comuns de morango da variedade Guarani, em função do tempo de armazenamento

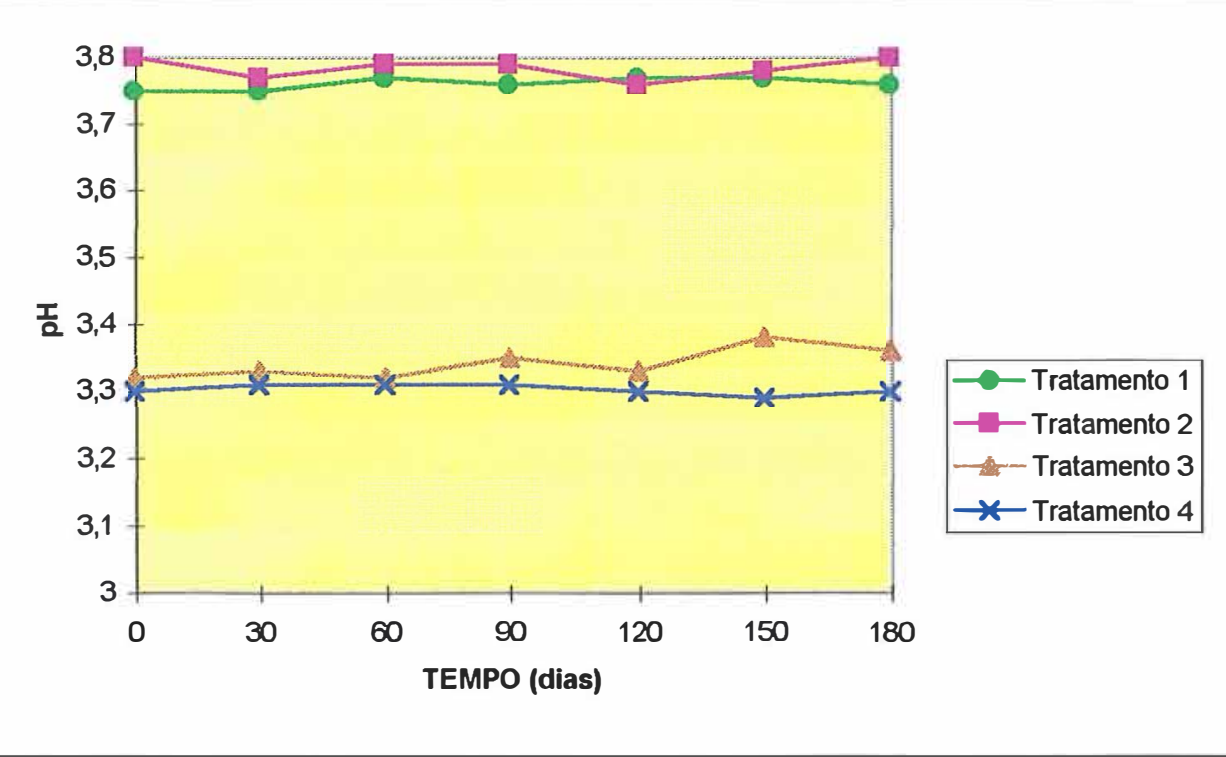

Figura 15 -Valores de $\mathrm{pH}$ dos néctares comuns de morango da variedade Oso Grande, em função do tempo de armazenamento 
Comparando-se as Tabelas 7 e 8, observa-se que, apesar da acidez total titulável dos néctares das duas variedades ter variado em função do tempo de armazenamento, o mesmo não ocorreu em relação ao $\mathrm{pH}$, sendo este mantido praticamente estável. Segundo Chitarra \& Chitarra (1990), numa faixa de concentração de ácido entre 2,5 e 0,5\%, o pH aumenta com a redução da acidez, sendo utilizado como indicativo dessa variação; porém, a capacidade tampão de algumas substâncias permite que ocorram grandes variações na acidez titulável, sem variações apreciáveis no $\mathrm{pH}$.

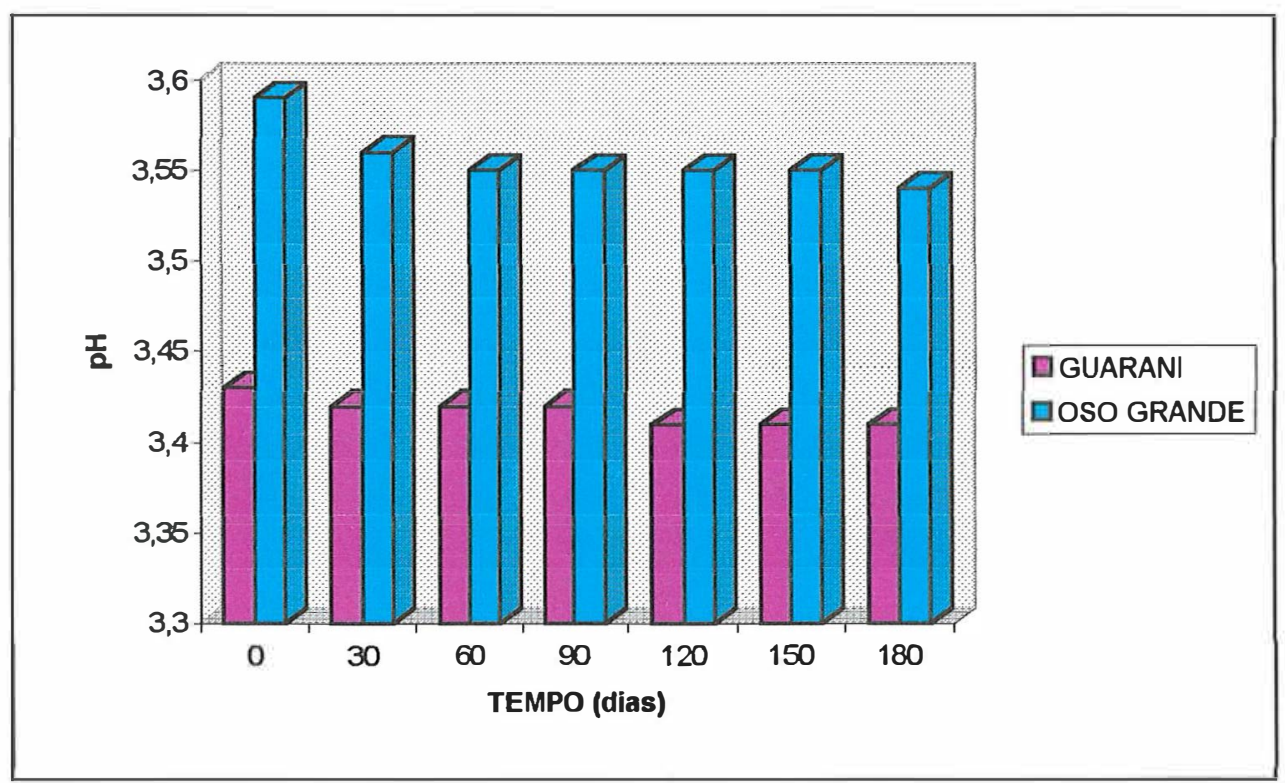

Figura 16 - Valores de $\mathrm{pH}$ dos néctares comuns de morango, em função do tempo de armazenamento

Os valores médios de sólidos solúveis totais, para os néctares das duas variedades em estudo (Tabela 9), mostraram que este parâmetro praticamente não se alterou em função dos tratamentos, bem como ao longo do período de armazenamento. 
Tabela 9 - Valores médios de sólidos solúveis totais ( $\left.{ }^{\circ} \mathrm{Brix}\right)$ dos néctares comuns de morango, em função do tempo de armazenamento

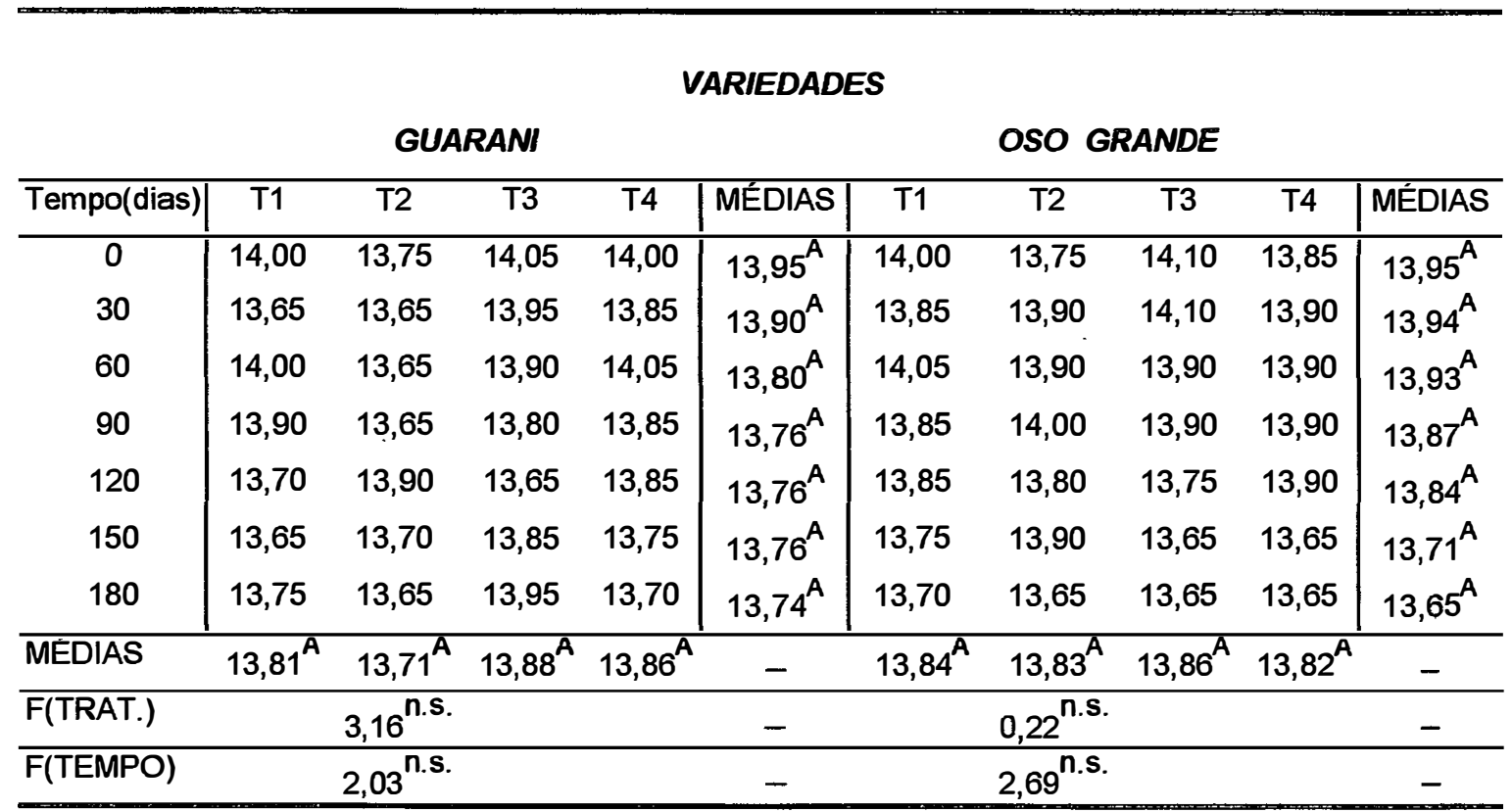

T1, T2, T3 e T4 = tratamentos

n.s. = não significativo

médias com a mesma letra não diferem entre si ao nível de $5 \%$ de significância

Aggarwal et al. (1992), Berbari et al.(1994) e Richards (1996) também não observaram mudanças nos valores de sólidos solúveis totais em néctar de pêssego, morangos congelados e morangos em calda, respectivamente, produtos estes também armazenados por seis meses.

Comparando-se os valores médios dos néctares das duas variedades (Figura 17), observa-se que a variedade Oso Grande, que apresentou matériaprima com maior teor de sólidos solúveis em relação à Guarani, manteve os néctares também com valores médios superiores aos da outra variedade até os 120 dias de armazenamento. A partir desta etapa, os valores da Oso Grande apresentaram quedas $(13,71$ e 13,65$)$, enquanto que os néctares da Guarani 
permaneceram quase que estáveis durante este período no que diz respeito aos sólidos soúveis totais.

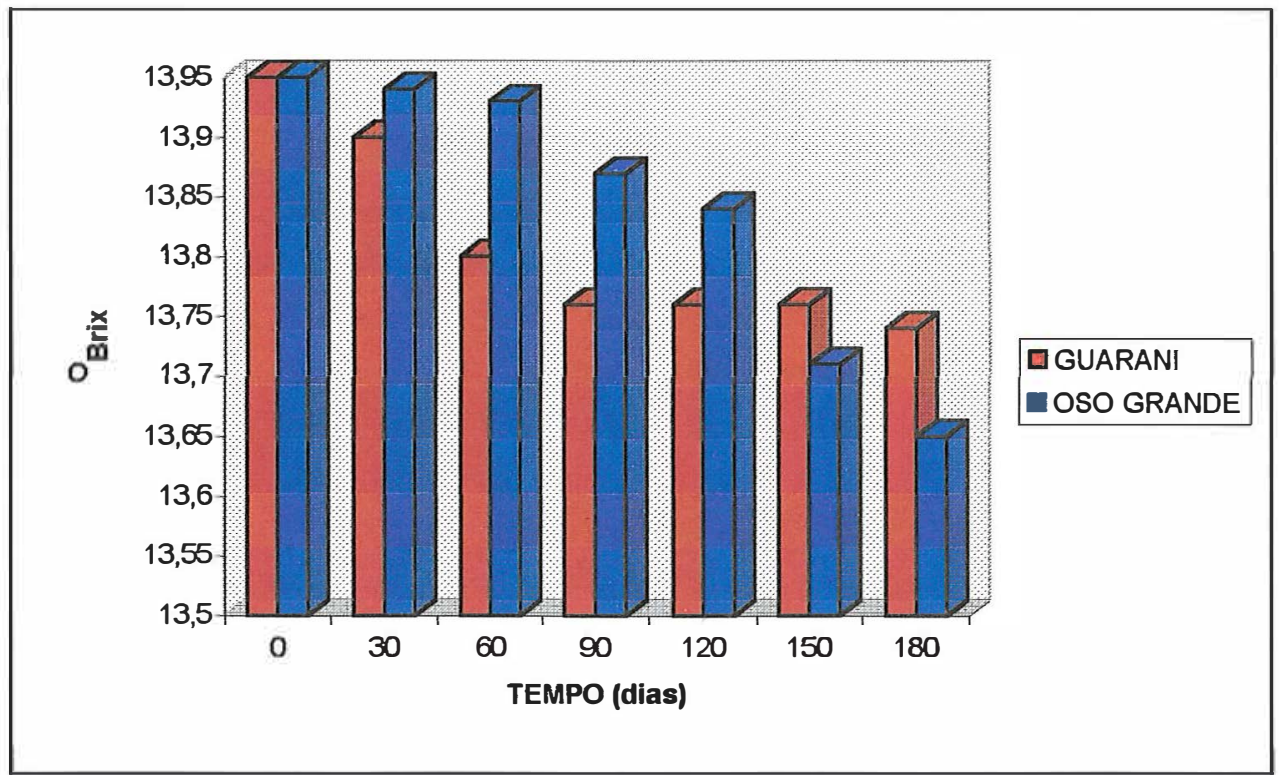

Figura 17 - Teores de sólidos solúveis totais dos néctares comuns de morango, em função do tempo de armazenamento

\subsection{3 - Análise sensorial}

A avaliação subjetiva da cor dos néctares das duas variedades (Tabela 10), mostrou que a menor média foi apresentada pelos tratamentos nos quais houve adição de ácido ascórbico (T4), e que este diferiu significativamente dos demais tratamentos (médias das notas: 6,62 e 4,83, respectivamente para as variedades Guarani e Oso Grande). Isto vem confirmar os estudos feitos por Askar et al. (1994), Bakker et al. (1992), Bakker \& Bridle (1992) e Cash \& Sistrunk (1970), nos quais estes autores também observaram que a descoloração das antocianinas foi acelerada pela presença daquele ácido. 
Para o néctar da variedade Oso Grande (Tabela 10), constatou-se que o Tratamento 3, o qual recebeu adição de ácido cítrico, apresentou notas médias superiores $(6,38=$ cor regular a boa) em relação aos demais tratamentos. A perda da coloração dos néctares da variedade Guarani foi significativa a partir dos noventa dias de armazenamento (Tabela 11), enquanto que para a variedade Oso Grande, após sessenta dias já foi observada diferença estatística ao nível de $5 \%$ de significância. Dentre as variedades, os néctares da Guarani apresentaram valores médios superiores aos da variedade Oso Grande, já que a matéria-prima da variedade Guarani apresentava coloração vermelha mais intensa (Figura 18).

Hudson et al. (1975), Spayd \& Morris (1982) e Spayd et al. (1982) também observaram que o ácido cítrico melhorou a estabilidade da cor em produtos de morango.

Tabela 10 - Valores médios das análises sensoriais dos néctares comuns de morango, em função dos tratamentos

VARIEDADES

GUARANI OSO GRANDE

\begin{tabular}{c|ccc|ccc}
\hline TRATAMENTOS & COR & CONSIST. & SABOR & COR & CONSIST. & SABOR \\
\hline T1 & $6,67^{\mathrm{A}}$ & $7,25^{\mathrm{A}}$ & $6,67^{\mathrm{A}}$ & $5,46^{\mathrm{B}}$ & $6,54^{\mathrm{A}}$ & $6,58^{\mathrm{A}}$ \\
T2 & $7,42^{\mathrm{A}}$ & $7,04^{\mathrm{A}}$ & $7,00^{\mathrm{A}}$ & $5,67^{\mathrm{B}}$ & $6,88^{\mathrm{A}}$ & $6,13^{\mathrm{AB}}$ \\
T3 & $7,42^{\mathrm{A}}$ & $7,03^{\mathrm{A}}$ & $6,79^{\mathrm{A}}$ & $6,38^{\mathrm{A}}$ & $6,54^{\mathrm{A}}$ & $6,29^{A B}$ \\
T4 & $6,62^{\mathrm{B}}$ & $6,75^{\mathrm{A}}$ & $6,00^{\mathrm{B}}$ & $4,83^{\mathrm{C}}$ & $6,54^{\mathrm{A}}$ & $5,71^{\mathrm{B}}$ \\
\hline F(Tratam.) & $9,35^{\star \star}$ & $1,20^{\text {n.s. }}$ & $7,40^{\star \star}$ & $17,61^{\star \star}$ & $1,17^{\text {n.s. }}$ & $4,61^{\star \star}$ \\
\hline F(Variedades) & $151,80^{\star \star}$ & $9,87^{\star \star}$ & $14,13^{\star \star}$ & $151,80^{\star \star}$ & $9,87^{\star \star}$ & $14,13^{\star \star}$
\end{tabular}

n.s. = não significativo

** = significativo ao nivel de $1 \%$

médias com a mesma letra, no sentido vertical, não diferem entre si ao nivel de $5 \%$ de significância 
Tabela 11 - Valores médios das análises sensoriais dos néctares comuns de morango, em função do tempo de armazenamento

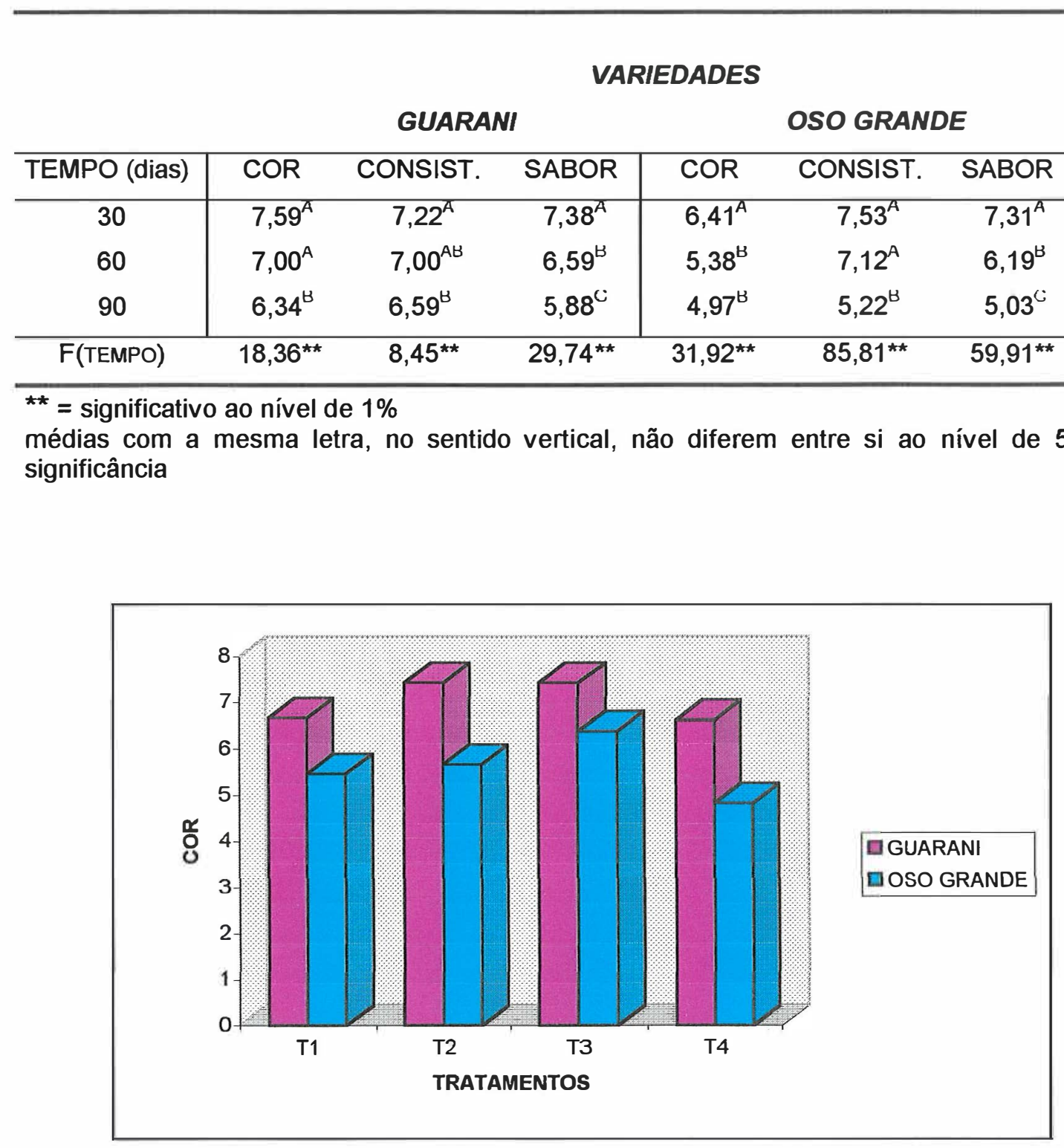

Figura 18 - Valores médios das notas obtidas na avaliação sensorial, quanto à cor dos néctares comuns de morango

Quanto à consistência, observa-se que os tratamentos das duas variedades não diferiram significativamente entre si (Tabela 10). Porém, é 
importante ressaltar, conforme mostra a Tabela 11, que com o passar do tempo de armazenamento as notas médias da consistência diminuíram.

Comparando-se os néctares das duas variedades (Figura 19), verifica-se que a Guarani foi a que resultou em um produto com melhor consistência. Este fato pode estar ligado ao teor de sólidos solúveis, pois como a variedade Guarani apresentou néctares com menores teores de sólidos em relação aos néctares da Oso Grande, conseqüentemente proporcionou uma consistência mais fluida, e portanto, um néctar mais agradável.

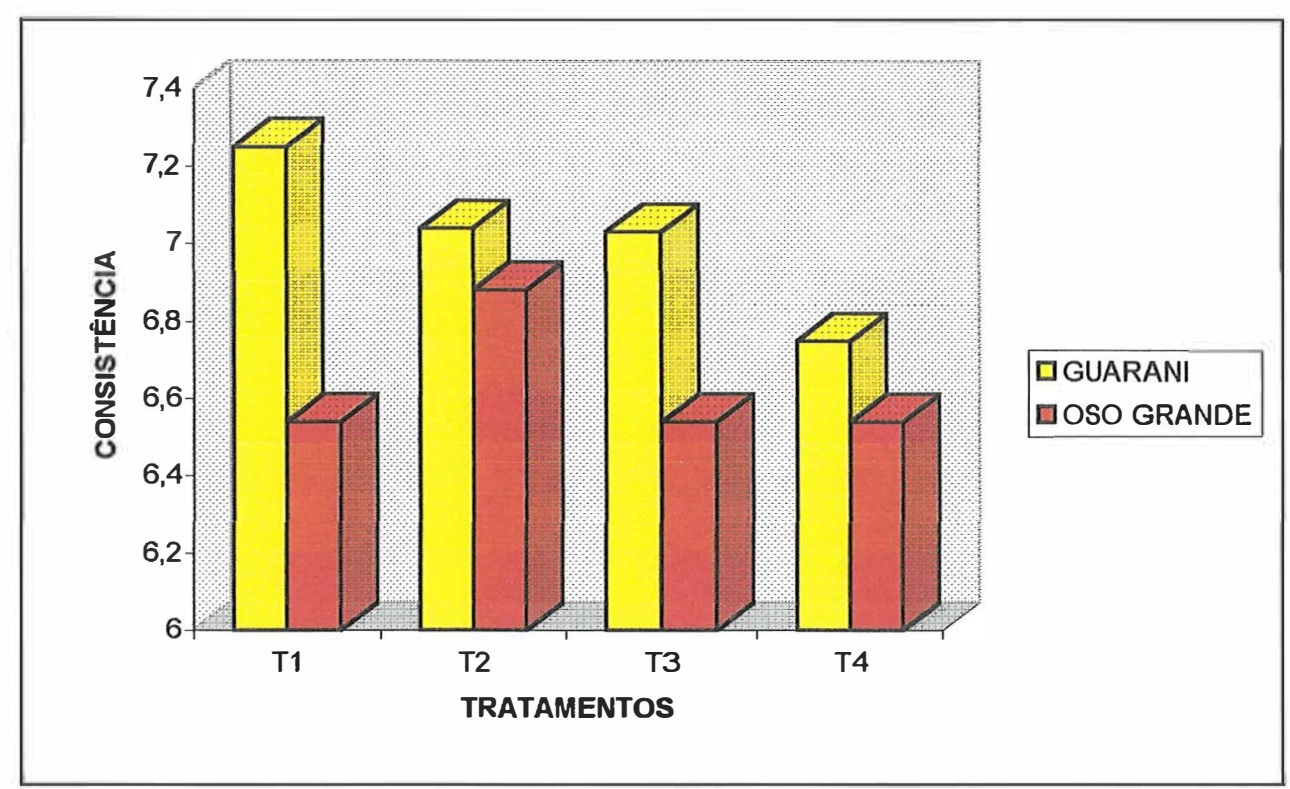

Figura 19 - Valores médios das notas obtidas na avaliação sensorial, quanto à consistência dos néctares comuns de morango

Para os néctares da variedade Guarani, observa-se pela Tabela 10 que o tratamento 4, que recebeu adição de ácido ascórbico apresentou, quanto ao sabor, nota inferior ( $6=$ regular) em relação aos demais tratamentos. Isto 
demonstra que a preferência em relação ao sabor é para os néctares menos ácidos. Para os néctares da variedade Oso Grande, observou-se diferença significativa entre os tratamentos 1 (nota 6,58 = regular a bom) e 4 (nota 5,71 $=$ regular $)$.

O sabor dos néctares das duas variedades também diminuiu com o período de armazenamento, sendo que os da variedade Guarani apresentaram notas médias superiores aos da variedade Oso Grande (Figura 20), caracterizando assim um néctar de morango mais saboroso.

De um modo geral, conforme ilustra a Figura 21, pode-se dizer que os néctares da variedade Guarani foram superiores aos da Oso Grande em relação à cor, consistência e sabor, durante os seis meses de armazenamento.

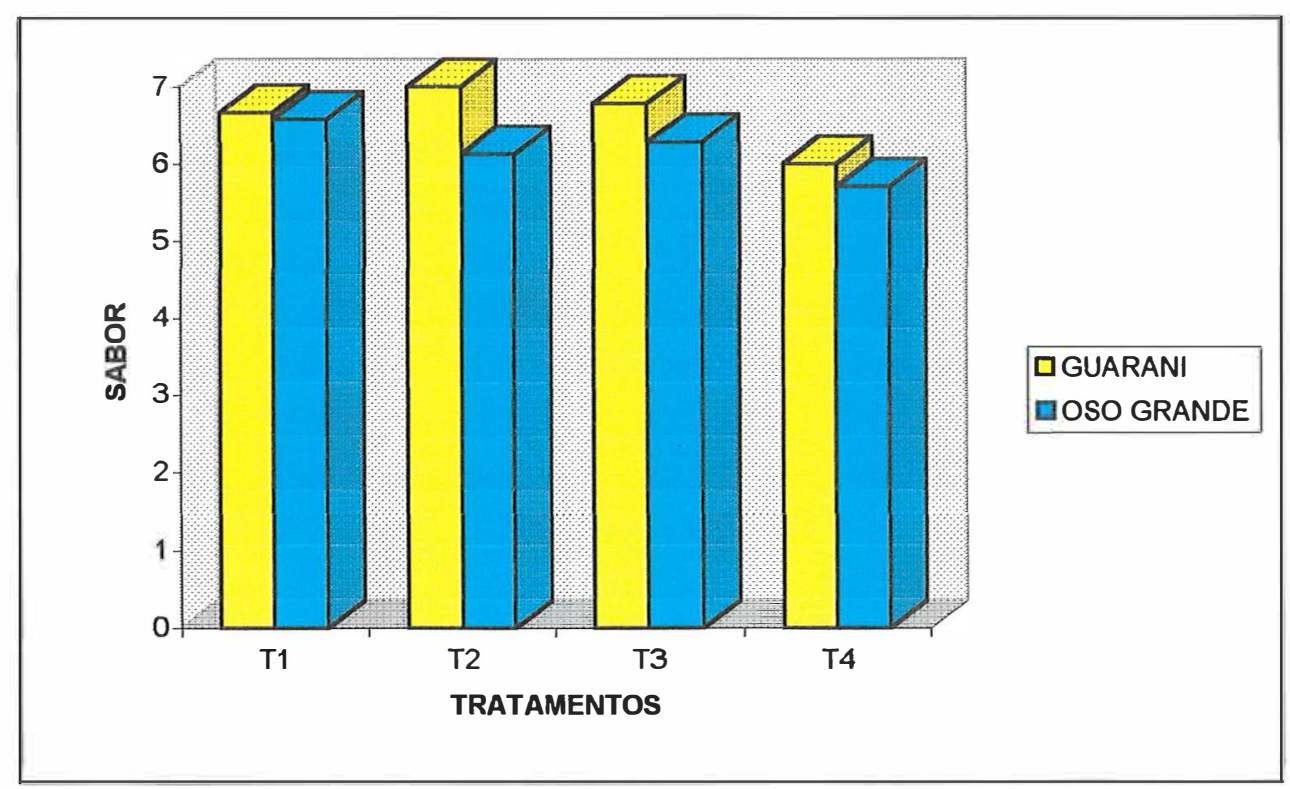

Figura 20 - Valores médios das notas obtidas na avaliação sensorial, quanto ao sabor dos néctares comuns de morango 


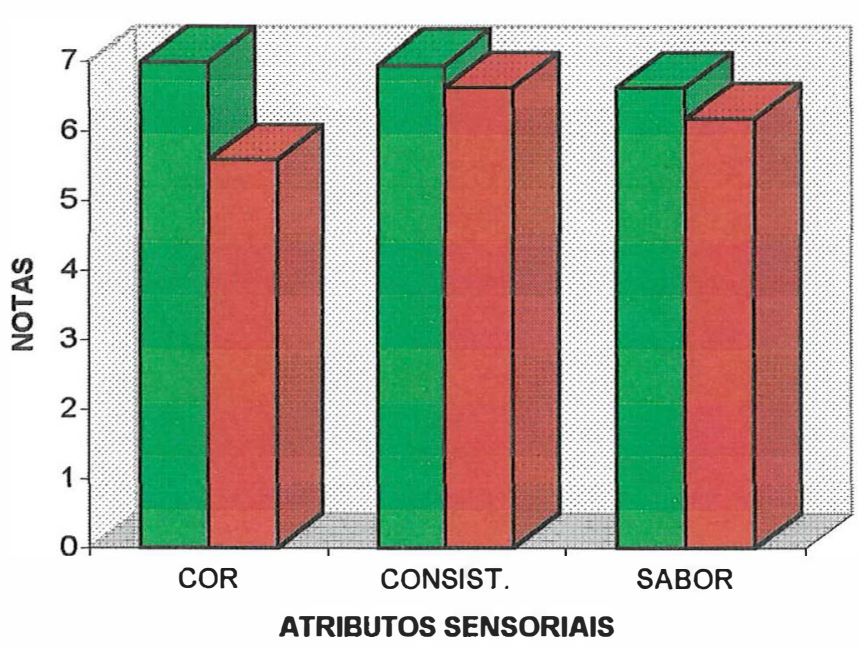

Figura 21 - Valores médios das notas obtidas na avaliação sensorial, quanto aos atributos de qualidade dos néctares comuns de morango

\section{3 - Caracterização do néctar dietético}

\subsection{1 - Análises físicas}

Na Tabela 12 são apresentados os resultados dos valores médios de vácuo das latas dos néctares dietéticos das variedades Guarani e Oso Grande. Por esta determinação, é possivel observar que tanto para a variedade Guarani, como para a Oso Grande, os valores médios de vácuo estão dentro da faixa adequada (entre 8 e 15 pol. $\mathrm{Hg}$ ), conforme indicado por Martin (1965/66) , e que também, como no caso dos néctares comuns, não houve variações significativas neste parâmetro, o que é altamente desejável, conforme já explicado anteriormente. 
Tabela 12 - Valores médios de vácuo (pol. $\mathrm{Hg}$ ) das latas dos néctares dietéticos de morango, em função do tempo de armazenamento

\begin{tabular}{c|ccc|c|cccc|c}
\hline \multicolumn{1}{c}{ VARIEDADES } \\
\multicolumn{1}{c}{ GUARANI } \\
\hline Tempo(dias) & T1 & T2 & T3 & MÉDIAS & T1 & T2 & T3 & T4 & MÉDIAS \\
\hline 0 & 11,75 & 11,50 & 11,50 & $11,58^{\mathrm{A}}$ & 12,75 & 12,75 & 12,25 & 12,75 & $13,63^{\mathrm{A}}$ \\
30 & 10,75 & 10,75 & 12,75 & $11,42^{\mathrm{A}}$ & 12,25 & 13,25 & 12,75 & 11,75 & $12,50^{\mathrm{A}}$ \\
60 & 11,75 & 11,75 & 12,50 & $12,00^{\mathrm{A}}$ & 11,75 & 12,25 & 12,75 & 11,75 & $12,13^{\mathrm{A}}$ \\
90 & 12,00 & 10,75 & 12,50 & $11,75^{\mathrm{A}}$ & 12,75 & 12,25 & 12,00 & 12,75 & $12,44^{\mathrm{A}}$ \\
120 & 11,00 & 12,00 & 12,75 & $11,92^{\mathrm{A}}$ & 11,75 & 11,75 & 11,50 & 12,50 & $11,87^{\mathrm{A}}$ \\
150 & 11,50 & 11,25 & 11,50 & $11,42^{\mathrm{A}}$ & 10,75 & 11,75 & 11,25 & 11,75 & $11,37^{\mathrm{A}}$ \\
180 & 11,75 & 12,75 & 10,50 & $11,67^{\mathrm{A}}$ & 12,25 & 12,50 & 12,25 & 12,00 & $12,25^{\mathrm{A}}$ \\
\hline MÉDIAS & $11,50^{\mathrm{A}}$ & $11,54^{\mathrm{A}}$ & $12,00^{\mathrm{A}}$ & - & $12,03^{\mathrm{A}}$ & $12,36^{\mathrm{A}}$ & $12,11^{\mathrm{A}}$ & $12,18^{\mathrm{A}}$ & - \\
\hline F(TRAT.) & \multicolumn{7}{c}{$0,68^{\text {n.S. }}$} \\
\hline F(TEMPO) & $0,84^{\text {n.S. }}$ \\
\hline
\end{tabular}

T1, T2, T3 e T4 = tratamentos

n.s. $=$ não significativo

médias com a mesma letra não diferem entre si ao nível de $5 \%$ de significância

Segundo Alves \& Garcia (1993), a estabilidade dos sucos de frutas, uma vez solucionados os aspectos microbiológico e enzimático, é determinada pela ocorrência de reações químicas, normalmente de natureza oxidativa, que comprometem suas características organolépticas e o seu valor nutricional. Além disso, a embalagem deve também apresentar formato e resistência físicomecânica adequados, de modo a não se deformar devido aos níveis de vácuo após o resfriamento.

Logo, a embalagem, para ser utilizada em processos de pasteurização ou de enchimento a quente, deve apresentar resistência térmica e mecânica para suportar as condições de temperatura do processo.

Askar et al. (1993) e Richards (1996) também observaram que o processo de desaeração e o enchimento das latas a quente, em néctares de 
manga, foram importantes na redução do teor de oxigênio no produto. Dessa forma, é de suma importância que o preenchimento a quente do néctar seja feito de maneira adequada, a fim de se obter um vácuo estável e dentro dos limites exigidos.

Em relação ao pesos bruto e líqüido (Tabelas 13 e 14), das latas dos néctares das duas variedades, também observa-se uma uniformidade nas análises, não constatando diferenças significativas entre os tratamentos, bem como em função do tempo de armazenamento. Como no caso dos néctares comuns, o preenchimento das latas dos néctares dietéticos também foi feito de maneira uniforme, obtendo-se assim um produto final de boa qualidade, do ponto de vista físico.

Tabela 13 - Valores médios do peso bruto $(\mathrm{g})$ das latas dos néctares dietéticos de morango, em função do tempo de armazenamento

\begin{tabular}{|c|c|c|c|c|c|c|c|c|c|}
\hline \multicolumn{10}{|c|}{ VARIEDADES } \\
\hline & \multicolumn{3}{|c|}{ GUARANI } & \multicolumn{6}{|c|}{ OSO GRANDE } \\
\hline Tempo(dias) & T1 & T2 & T3 & MÉDIAS & T1 & T2 & T3 & T4 & MÉDIAS \\
\hline 0 & 405,9 & 408,6 & 407,6 & $407,4^{A}$ & 408,7 & 408,2 & 407,9 & 407,7 & $408,1^{A}$ \\
\hline 30 & 400,1 & 406,3 & 411,2 & $405,9^{A}$ & 408,3 & 408,4 & 407,7 & 408,4 & $408,2^{A}$ \\
\hline 60 & 412,5 & 402,1 & 403,4 & $405,9^{A}$ & 407,5 & 407,5 & 407,8 & 408,3 & $407,8^{A}$ \\
\hline 90 & 404,3 & 411,1 & 402,5 & $406,0^{A}$ & 407,9 & 408,5 & 408,7 & 410,1 & $408,8^{A}$ \\
\hline 120 & 410,2 & 403,6 & 405,6 & $406,5^{A}$ & 407,7 & 408,0 & 408,8 & 409,8 & $408,6^{A}$ \\
\hline 150 & 401,1 & 404,2 & 408,9 & $404,7^{\mathrm{A}}$ & 406,6 & 408,4 & 406,8 & 409,4 & $407,8^{A}$ \\
\hline 180 & 395,6 & 404,6 & 407,6 & $402,6^{A}$ & 408,4 & 408,2 & 407,2 & 410,2 & $408,5^{A}$ \\
\hline MÉDIAS & $404,2^{A}$ & $405,8^{A}$ & $406,7^{A}$ & - & $407,9^{A}$ & $408,1^{A}$ & $407,8^{A}$ & $409,1^{A}$ & - \\
\hline F(TRAT.) & & $0,49^{\text {n.s. }}$ & & - & & $4,95^{\text {n.s. }}$ & & & - \\
\hline F(TEMPO) & & $1,17^{\text {n.s. }}$ & & - & & $0,13^{\text {n.s. }}$ & & & - \\
\hline
\end{tabular}

T1, T2, T3 e T4 = tratamentos

n.s. = não significativo

médias com a mesma letra não diferem entre si ao nivel de $5 \%$ de significância 
Tabela 14 - Valores médios do peso líqüido $(\mathrm{g})$ das latas dos néctares dietéticos de morango, em função do tempo de armazenamento

\begin{tabular}{|c|c|c|c|c|c|c|c|c|c|}
\hline \multicolumn{10}{|c|}{ VARIEDADES } \\
\hline & \multicolumn{3}{|c|}{ GUARANI } & \multicolumn{6}{|c|}{ OSO GRANDE } \\
\hline$\overline{T e m p o(d i a s)}$ & T1 & T2 & $\overline{T 3}$ & MÉDIAS & T1 & T2 & T3 & $\overline{T 4}$ & MÉDIAS \\
\hline 0 & 339,6 & 352,1 & 351.8 & $347,8^{A}$ & 351,5 & 351,7 & 350,2 & 351,9 & $351,3^{A}$ \\
\hline 30 & 343,8 & 349,1 & 354.6 & $349,2^{A}$ & 352,2 & 350,6 & 349,4 & 350,3 & $350,6^{A}$ \\
\hline 60 & 355,4 & 345,2 & 346.2 & $348,9^{A}$ & 351,2 & 352,1 & 351,0 & 351,8 & $351,5^{\mathrm{A}}$ \\
\hline 90 & 347,5 & 354,6 & 344.2 & $348,8^{A}$ & 352,0 & 350,4 & 348,9 & 350,5 & $350,5^{\mathrm{A}}$ \\
\hline 120 & 354,2 & 346,0 & 344.4 & $348,2^{A}$ & 352,4 & 350,6 & 349,9 & 351,9 & $351,2^{A}$ \\
\hline 150 & 348,9 & 345,7 & 345.2 & $346,6^{A}$ & 352,2 & 349,9 & 352,2 & 350,3 & $351,2^{A}$ \\
\hline 180 & 341,3 & 347,3 & 342.3 & $343,6^{A}$ & 351,0 & 350,3 & 352,3 & 349,3 & $350,8^{A}$ \\
\hline MÉDIAS & $347,3^{A}$ & $348,6^{A}$ & $346.9^{A}$ & - & $351,8^{A}$ & $350,8^{A}$ & $350,5^{\mathrm{A}}$ & $350,9^{A}$ & - \\
\hline F(TRAT.) & & $0,17^{\text {n.s }}$ & & - & & $2,03^{\text {n.s. }}$ & & & - \\
\hline$\overline{F(T E M P O)}$ & & $1,84^{\text {n.S. }}$ & & - & & $0,15^{\text {n.s. }}$ & & & - \\
\hline
\end{tabular}

T1, T2, T3 e T4 = tratamentos

n.s. = não significativo

médias com a mesma letra não diferem entre si ao nível de $5 \%$ de significância

\subsection{2 - Análises químicas}

Na Tabela 15 são apresentados os valores de ácido ascórbico dos néctares dietéticos das variedades em estudo. Pela análise dos resultados pode-se dizer que, ao longo do tempo de armazenamento, as perdas de ácido ascórbico foram estatisticamente significativas ao nível de 1\%. Em relação aos tratamentos dos néctares da variedade Guarani, observa-se que o tratamento 3 (que recebeu adição de ácido ascórbico) diferiu dos demais tratamentos, como era de se esperar. A Figura 22 ilustra as perdas de ácido ascórbico dos néctares da variedade Guarani, em função do tempo de armazenamento.

Para a variedade Oso Grande observa-se também que o tratamento que recebeu adição de ácido ascórbico (T4) diferiu dos demais; o tratamento 3 , 
que recebeu adição de ácido cítrico, foi estatisticamente superior aos tratamentos 1 e 2 (Figura 23). Hudson et al. (1975) também observaram que a adição de ácido cítrico em morangos congelados melhorou a retenção de ácido ascórbico nestes produtos. Aggarwal et al., (1992), Aradhita et al., (1995), Askar et al. (1996) e Diéz et al.(1995) também observaram perdas no conteúdo de ácido ascórbico em néctares de pêssego, goiaba, manga e abacaxi, respectivamente, ao longo do período de armazenamento.

Comparando-se os teores de ácido ascórbico, entre os néctares das variedades em estudo (Figura 24), observa-se que, como no caso anterior, a variedade Guarani apresentou maiores teores deste ácido ao longo do período de armazenamento, em relação à Oso Grande.

Tabela 15 - Valores médios dos teores de ácido ascórbico $(\mathrm{mg} / 100 \mathrm{~g})$ dos néctares dietéticos de morango, em função do tempo de armazenamento

\begin{tabular}{|c|c|c|c|c|c|c|c|c|c|}
\hline \multirow[b]{3}{*}{ Tempo(dias) } & \multicolumn{9}{|c|}{ VARIEDADES } \\
\hline & \multicolumn{3}{|c|}{ GUARANI } & \multicolumn{6}{|c|}{ OSO GRANDE } \\
\hline & T1 & T2 & T3 & MÉDIAS & T1 & T2 & T3 & T4 & MEDIAS \\
\hline 0 & 42,85 & 44,10 & 72,71 & $53,22^{A}$ & 34,14 & 39,92 & 40,50 & 69,75 & $46,83^{A}$ \\
\hline 30 & 41,00 & 40,75 & 68,02 & $49,93^{A B}$ & 33,89 & 39,33 & 39,75 & 65,90 & $44,72^{A}$ \\
\hline 60 & 40,14 & 36,24 & 63,33 & $46,57^{\mathrm{BC}}$ & 31,43 & 33,64 & 37,14 & 60,97 & $40,80^{B}$ \\
\hline 90 & 36,25 & 35,75 & 60,51 & $44,17^{\mathrm{CD}}$ & 30,62 & 27,50 & 34,00 & 51,70 & $35,97^{\mathrm{C}}$ \\
\hline 120 & 32,50 & 34,10 & 56,10 & $40,90^{\mathrm{DE}}$ & 26,83 & 27,13 & 31,75 & 49,74 & $33,85^{\mathrm{C}}$ \\
\hline 150 & 27,50 & 31,00 & 52,25 & $36,92^{\mathrm{EF}}$ & 26,19 & 26,75 & 29,50 & 46,40 & $32,21^{\mathrm{CD}}$ \\
\hline 180 & 24,32 & 27,51 & 51,35 & $34,40^{\mathrm{F}}$ & 22,50 & 24,00 & 26,50 & 42,87 & $28,97^{\mathrm{D}}$ \\
\hline MÉDIAS & $34,94^{B}$ & $35,64^{B}$ & $60,61^{A}$ & - & $29,80^{C}$ & $31,18^{C}$ & $34,16^{\mathrm{B}}$ & $55,33^{A}$ & - \\
\hline F(TRAT.) & & $136,96^{\star \star}$ & & - & & $448,49^{\star \star}$ & & & - \\
\hline$\overline{F(T E M P O)}$ & & $60,23^{\star \star}$ & & - & & $40,58^{\text {\#t }}$ & & & - \\
\hline
\end{tabular}

T1, T2, T3 e T4 = tratamentos

** = significativo ao nível de $1 \%$

médias com a mesma letra não diferem entre si ao nível de $5 \%$ de significância 


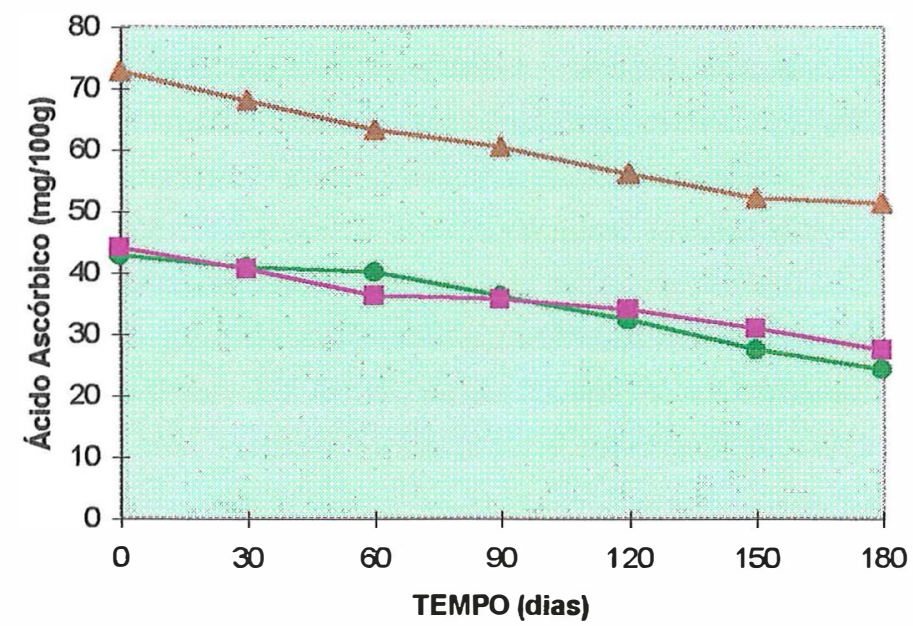

- Tratamento 1

- Tratamento 2

- Tratamento 3

Figura 22 - Teores de ácido ascórbico dos néctares dietéticos de morango da variedade Guarani, em função do tempo de armazenamento
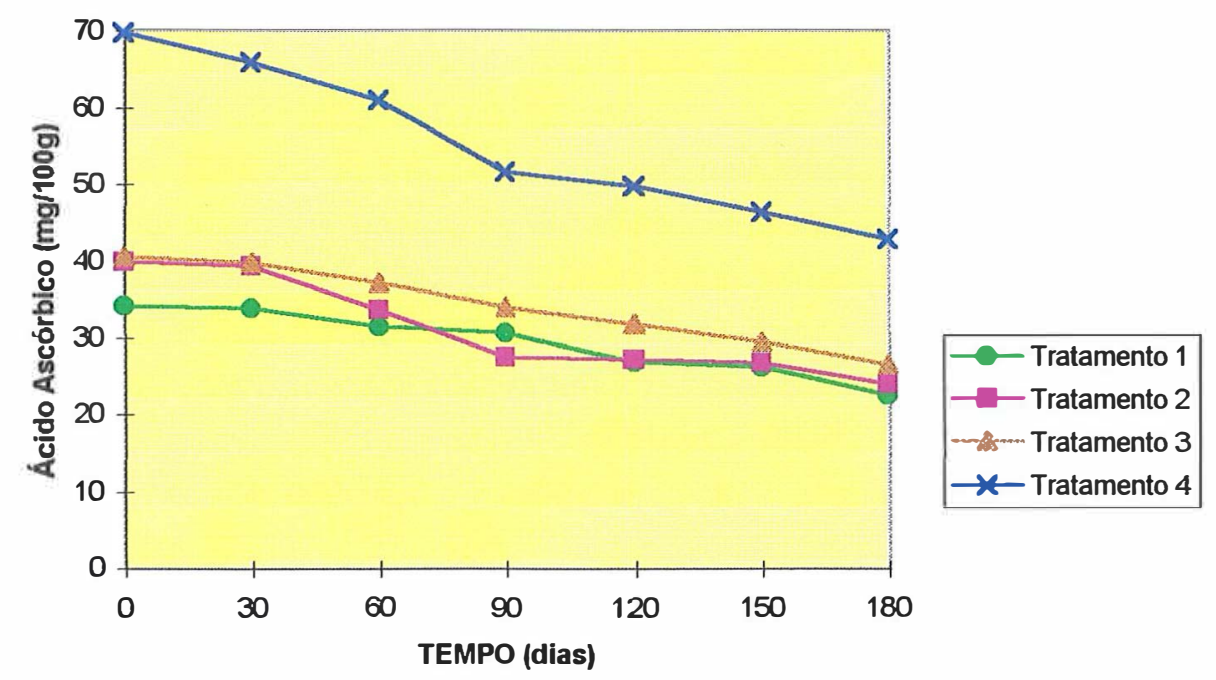

Figura 23 - Teores de ácido ascórbico dos néctares dietéticos de morango da variedade Oso Grande, em função do tempo de armazenamento 


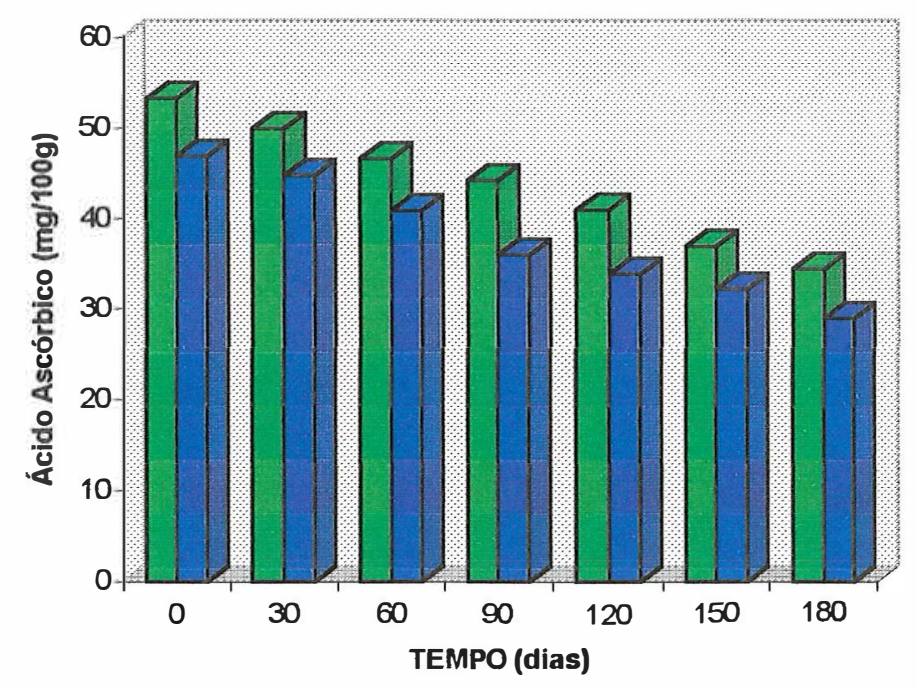

IGUARANI

- OSO GRANDE

Figura 24 - Teores de ácido ascórbico dos néctares dietéticos de morango, em função do tempo de armazenamento

As maiores perdas de ácido ascórbico dos néctares, para ambas as variedades, foram apresentadas pelo tratamento 1, onde não houve emprego de aditivos químicos. Goldoni et al. (1981) também observaram que a presença destes, em suco de morango, foi eficiente na conservação do ácido ascórbico.

Comparando-se as Tabelas 2 e 15, conclui-se que durante o processamento dos morangos e armazenamento dos néctares (T1 e T2), houve perdas de $50,09 \%$ e $55,84 \%$ nos teores de ácido ascórbico para os néctares das variedades Guarani e Oso Grande, respectivamente. Mesmo após seis meses de armazenamento, os néctares que não receberam adição de ácido ascórbico, T1 e T2 para a variedade Guarani e T1, T2 e T3 para a Oso Grande, ainda apresentaram razoáveis teores deste ácido (cerca de $25 \mathrm{mg} / 100 \mathrm{~g}$ ). Diáz et al. (1987) estudaram o teor de vitamina $\mathrm{C}$ em geléias dietéticas de morango e encontraram valores médios ao redor de $25 \mathrm{mg} / 100 \mathrm{~g}$ de amostra. 
Os tratamentos que receberam adição de ácido ascórbico (3 e 4 para as variedades Guarani e Oso Grande, respectivamente), permitiram que os néctares das duas variedades, após 180 dias de armazenamento, apresentassem teores médios finais bem superiores (cerca de $51 \mathrm{mg} / 100 \mathrm{~g}$ para a variedade Guarani e $43 \mathrm{mg} / 100 \mathrm{~g}$ para a Oso Grande) em relação aos demais tratamentos.

A Tabela 16 mostra que os valores médios de acidez total titulável dos néctares das duas variedades diminuiram signficativamente em função do período de armazenamento, como também mostra que houve diferenças entre os tratamentos. Os néctares da variedade Guarani apresentaram acidez mais pronunciada que os da Oso Grande (Figuras 25 e 26).

Tabela 16 - Valores médios de acidez total titulável (g ácido cítrico/100g) dos néctares dietéticos de morango, em função do tempo de armazenamento

VARIEDADES

\begin{tabular}{|c|c|c|c|c|c|c|c|c|c|}
\hline & \multicolumn{3}{|c|}{ GUARANI } & \multicolumn{6}{|c|}{ OSO GRANDE } \\
\hline Tempo(dias) & T1 & T2 & T3 & MÉDIAS & T1 & T2 & T3 & T4 & MEDIAS \\
\hline 0 & 0,295 & 0,310 & 0,355 & $0,320^{A}$ & 0,190 & 0,210 & 0,265 & 0,310 & $0,243^{A}$ \\
\hline 30 & 0,295 & 0,310 & 0,335 & $0,313^{A}$ & 0,175 & 0,205 & 0,255 & 0,305 & $0,235^{A B}$ \\
\hline 60 & 0,275 & 0,305 & 0,315 & $0,298^{A B}$ & 0,165 & 0,185 & 0,245 & 0,295 & $0,222^{B C}$ \\
\hline 90 & 0,255 & 0,275 & 0,300 & $0,276^{B C}$ & 0,165 & 0,175 & 0,245 & 0,285 & $0,217^{C}$ \\
\hline 120 & 0,245 & 0,260 & 0,275 & $0,260^{C D}$ & 0,160 & 0,165 & 0,230 & 0,275 & $0,207^{D}$ \\
\hline 150 & 0,235 & 0,250 & 0,255 & $0,246^{D}$ & 0,155 & 0,165 & 0,215 & 0,270 & $0,201^{D}$ \\
\hline 180 & 0,235 & 0,240 & 0,245 & $0,240^{D}$ & 0,135 & 0,145 & 0,205 & 0,245 & $0,182^{E}$ \\
\hline MÉDIAS & $0,262^{C}$ & $0,278^{B}$ & $0,297^{A}$ & - & $0,163^{D}$ & $0,178^{C}$ & $0,237^{B}$ & $0,283^{A}$ & - \\
\hline \multicolumn{2}{|l|}{$\overline{F(T R A T .)}$} & $851,76^{\star \star \star}$ & & - & & $23,99^{\star \star *}$ & & & 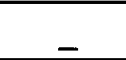 \\
\hline \multicolumn{2}{|l|}{ F(TEMPO) } & $37,63^{\star \star}$ & & - & & $30,35^{\star *}$ & & & \\
\hline
\end{tabular}

$\mathrm{T} 1, \mathrm{~T} 2, \mathrm{~T} 3$ e $\mathrm{T} 4$ = tratamentos

** $=$ significativo ao nível de $1 \%$

médias com a mesma letra não diferem entre si ao nível de $5 \%$ de significância 


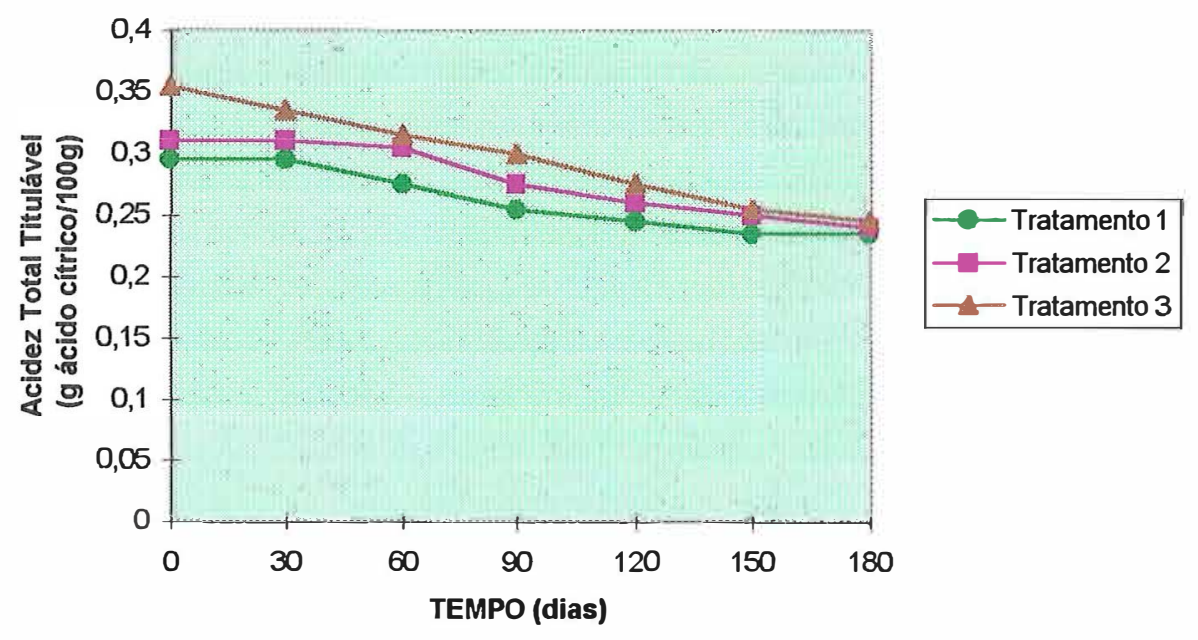

Figura 25 - Teores de acidez total titulável dos néctares dietéticos de morango da variedade Guarani, em função do tempo de armazenamento

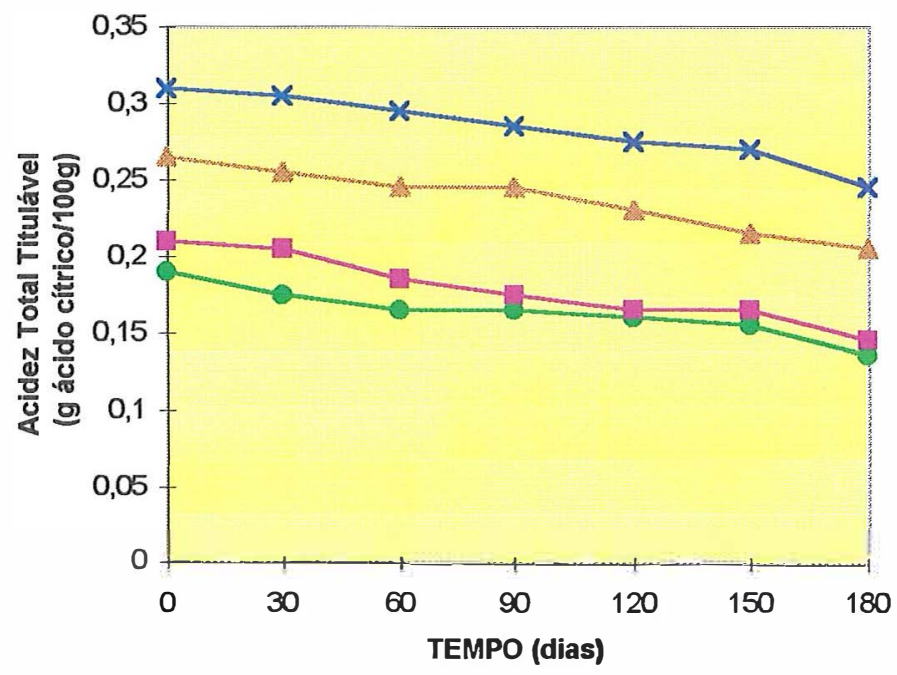

Figura 26 - Teores de acidez total titulável dos néctares dietéticos de morango da variedade Oso Grande, em função do tempo de armazenamento 
De um modo geral, observa-se que os néctares dietéticos da variedade Guarani apresentaram maior acidez do que os da outra variedade (Figura 27). Este fato também ocorreu nos néctares comuns, mostrando novamente que a matéria-prima com maior teor de acidez (Guarani), originou néctares também mais ácidos em relação aos da variedade Oso Grande.

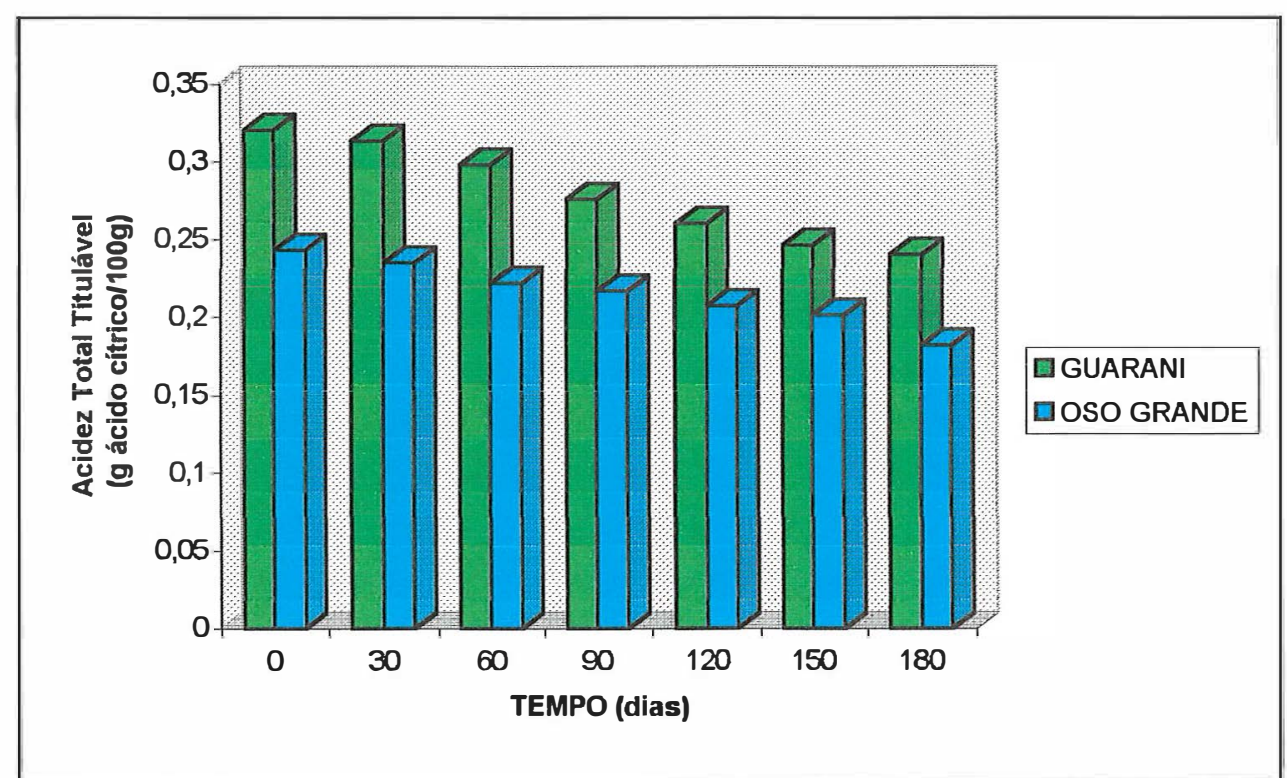

Figura 27 - Teores de acidez total titulável dos néctares dietéticos de morango, em função do tempo de armazenamento

Os resultados dos valores médios de $\mathrm{pH}$ dos néctares dietéticos, mostrados na Tabela 17, indicam que houve variações significativas ao nível de $1 \%$ somente em relação aos tratamentos, porém, os valores de $\mathrm{pH}$ destes não foram estatisticamente influenciados pelo tempo de armazenamento (Figuras 27 e 28). Para os néctares da variedade Guarani, verifica-se que o tratamento 2 apresentou valores médios de $\mathrm{pH}$ significativamente superiores aos dos tratamentos 1 e 3 . No caso da variedade Oso Grande, o tratamento 2 
também mostrou-se mais ácido que os tratamentos 3 e 4, porém, não diferiu estatisticamente do tratamento 1.

Comparando-se as Tabelas 16 e 17, observa-se que, apesar dos valores de acidez total titulável terem diminuído em função do tempo de estocagem dos néctares, o mesmo não aconteceu em relação aos valores de pH, já que estes parâmetros estão relacionados entre si. Este fato explicado por Chitarra \& Chitarra (1990) foi também observado nos néctares comuns deste trabalho.

Pela ilustração da Figura 30 é possível verificar que os néctares da variedade Guarani apresentaram valores médios de $\mathrm{pH}$ mais baixos que os da variedade Oso Grande.

Tabela 17 - Valores médios de pH dos néctares dietéticos de morango, em função do tempo de armazenamento

VARIEDADES

\begin{tabular}{|c|c|c|c|c|c|c|c|c|c|}
\hline & \multicolumn{3}{|c|}{ GUARANI } & \multicolumn{6}{|c|}{ OSO GRANDE } \\
\hline Tempo(dias) & T1 & T2 & T3 & MÉDIAS & T1 & T2 & T3 & T4 & |MEDIAS \\
\hline 0 & 3,53 & 3,61 & 3,38 & $3,52^{A}$ & 3,81 & 3,85 & 3,37 & 3,31 & $359^{A}$ \\
\hline 30 & 3,54 & 3,61 & 3,40 & $3,52^{A}$ & 3,82 & 3,82 & 3,38 & 3,31 & $3,59^{A}$ \\
\hline 60 & 3,53 & 3,59 & 3,39 & $3,51^{A}$ & 3,83 & 3,83 & 3,38 & 3,31 & $3,58^{\mathrm{A}}$ \\
\hline 90 & 3,55 & 3,62 & 3,36 & $3,51^{A}$ & 3,80 & 3,83 & 3,37 & 3,29 & $3,58^{A}$ \\
\hline 120 & 3,55 & 3,60 & 3,39 & $3,51^{\mathrm{A}}$ & 3,82 & 3,83 & 3,39 & 3,30 & $3,58^{\mathrm{A}}$ \\
\hline 150 & 3,53 & 3,60 & 3,38 & $3,50^{\mathrm{A}}$ & 3,80 & 3,84 & 3,40 & 3,29 & $3,58^{\mathrm{A}}$ \\
\hline 180 & 3,57 & 3,58 & 3,37 & $3,50^{\mathrm{A}}$ & 3,82 & 3,81 & 3,41 & 3,30 & $3,57^{\mathrm{A}}$ \\
\hline MEDIAS & 3,54 & $3,60^{A}$ & $3,38^{c}$ & - & $3,81^{A}$ & $3,83^{A}$ & $3,38^{\mathrm{B}}$ & $3,30^{c}$ & \\
\hline F(TRAT.) & & $3,76^{\star \star}$ & & - & & $3,99^{\star \star}$ & & & \\
\hline F(TEMPO) & & $0,46^{\text {n.s }}$ & & - & & $0,71^{\text {n.s }}$ & & & \\
\hline
\end{tabular}

T1, T2, T3 e T4 = tratamentos

n.s. = não significativo

** $=$ significativo ao nivel de $1 \%$

médias com a mesma letra não diferem entre si ao nível de $5 \%$ de significância 


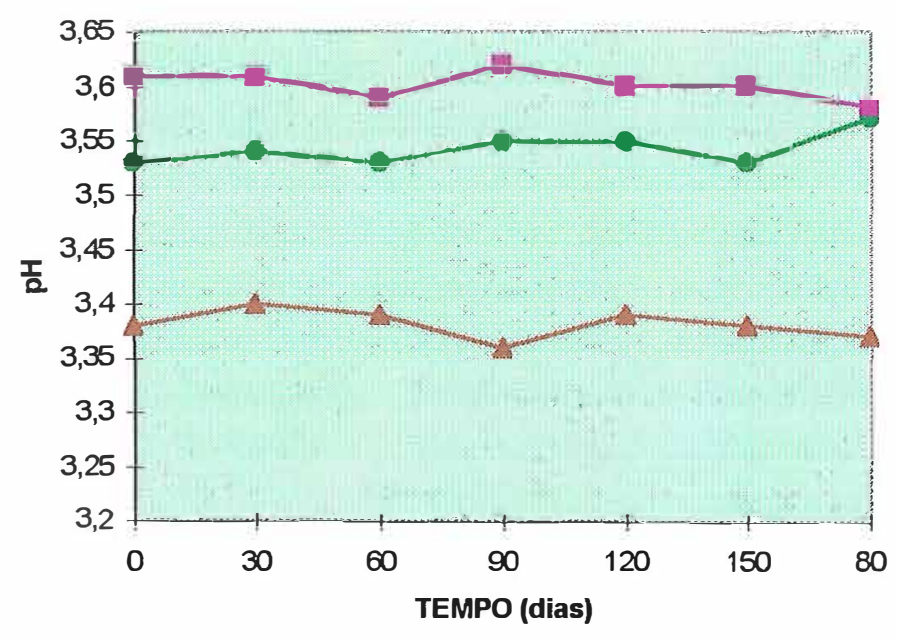

- Tratamento 1

- Tratamento 2

- Tratamento 3

Figura 28 - Valores de $\mathrm{pH}$ dos néctares dietéticos de morango da variedade Guarani, em função do tempo de armazenamento
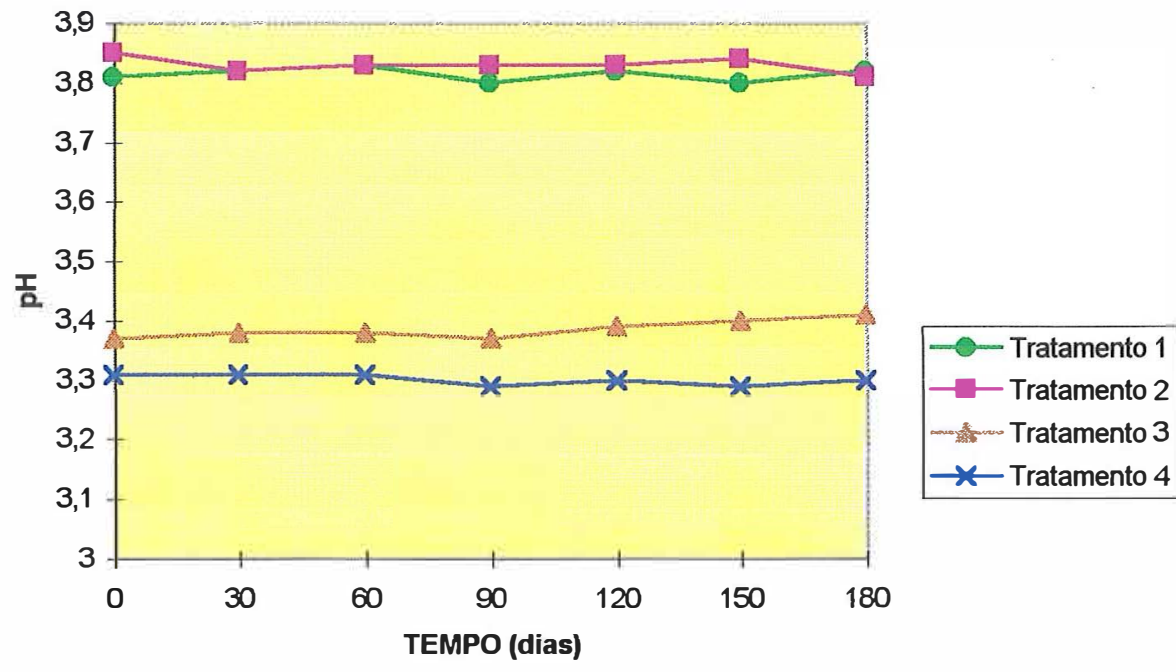

Figura 29 - Valores de $\mathrm{pH}$ dos néctares dietéticos de morango da variedade Oso Grande, em função do tempo de armazenamento 


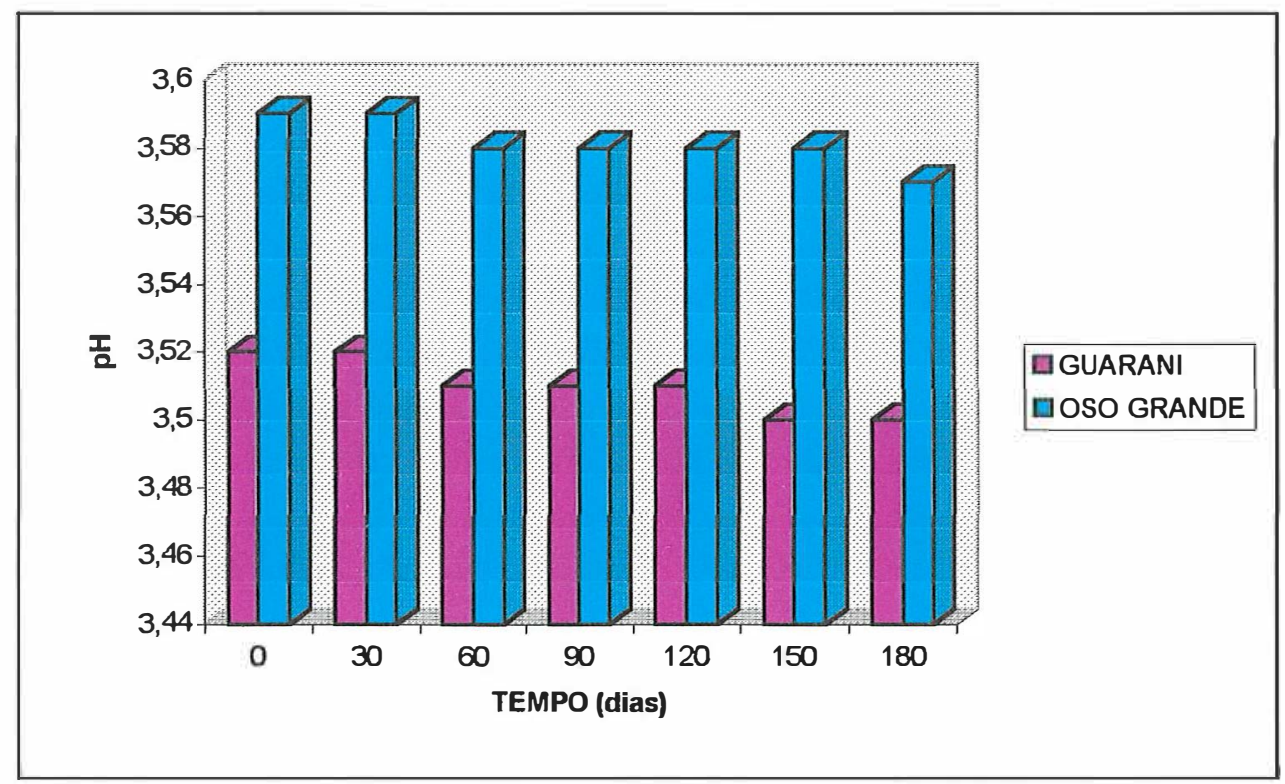

Figura 30 - Valores de pH dos néctares dietéticos de morango, em função do tempo de armazenamento

Quanto aos teores médios de sólidos solúveis totais (Tabela 18), pode-se dizer que os néctares das duas variedades apresentaram tendência de diminuição com o tempo de armazenamento (Figura 31), porém, estas variações não foram estatisticamente significativas. El-Zoghbi \& Siliha (1992) observaram uma acentuada queda nos valores de sólidos solúveis totais em néctares dietéticos de apricot.

\subsection{3 - Análise sensorial}

As Tabelas 19 e 20 mostram a avaliação subjetiva dos atributos sensoriais dos néctares dietéticos das duas variedades. Em relação às notas médias de cor, dadas aos néctares em função dos diferentes tratamentos (Tabela 19), é possivel observar, em ambas as variedades, que as menores médias foram constatadas onde houve adição de ácido ascórbico, tratamentos 
Tabela 18 - Valores médios de sólidos solúveis totais ( $\left.{ }^{\circ} \mathrm{Brix}\right)$ dos néctares dietéticos de morango, em função do tempo de armazenamento

\begin{tabular}{c|ccc|c|ccccc}
\hline \multicolumn{7}{c}{ VARIEDADES } \\
\multicolumn{10}{c}{ OSO GRANDE } \\
\hline Tempo(dias) & T1 & T2 & T3 & MÉDIAS & T1 & T2 & T3 & T4 & MÉDIAS \\
\hline 0 & 13,90 & 14,00 & 14,00 & $13,97^{\mathrm{A}}$ & 13,90 & 14,00 & 14,00 & 14,00 & $13,98^{\mathrm{A}}$ \\
30 & 13,65 & 13,95 & 13,90 & $13,90^{\mathrm{A}}$ & 14,00 & 13,90 & 13,85 & 13,85 & $13,90^{\mathrm{A}}$ \\
60 & 13,95 & 13,85 & 13,65 & $13,83^{\mathrm{A}}$ & 13,75 & 13,75 & 13,90 & 13,85 & $13,85^{\mathrm{A}}$ \\
90 & 13,85 & 13,95 & 13,90 & $13,83^{\mathrm{A}}$ & 13,90 & 13,95 & 13,85 & 13,90 & $13,84^{\mathrm{A}}$ \\
120 & 13,70 & 13,85 & 13,75 & $13,82^{\mathrm{A}}$ & 13,75 & 13,70 & 13,90 & 13,75 & $13,81^{\mathrm{A}}$ \\
150 & 13,55 & 14,20 & 13,75 & $13,77^{\mathrm{A}}$ & 13,90 & 13,90 & 13,70 & 13,70 & $13,77^{\mathrm{A}}$ \\
180 & 13,75 & 13,60 & 13,70 & $13,68^{\mathrm{A}}$ & 13,65 & 13,85 & 13,80 & 13,80 & $13,75^{\mathrm{A}}$ \\
\hline MÉDIAS & $13,76^{\mathrm{A}}$ & $13,91^{\mathrm{A}}$ & $13,80^{\mathrm{A}}$ & - & $13,83^{\mathrm{A}}$ & $13,85^{\mathrm{A}}$ & $13,85^{\mathrm{A}}$ & $13,83^{\mathrm{A}}$ & - \\
\hline F(TRAT.) & \multicolumn{7}{c}{$0,10^{\text {n.S. }}$} \\
\hline F(TEMPO) & $1,85^{\text {n.S. }}$ \\
\hline
\end{tabular}

$\mathrm{T} 1, \mathrm{~T} 2, \mathrm{~T} 3$ e $\mathrm{T} 4$ = tratamentos

n.s. = não significativo

médias com a mesma letra não diferem entre si ao nível de $5 \%$ de significância

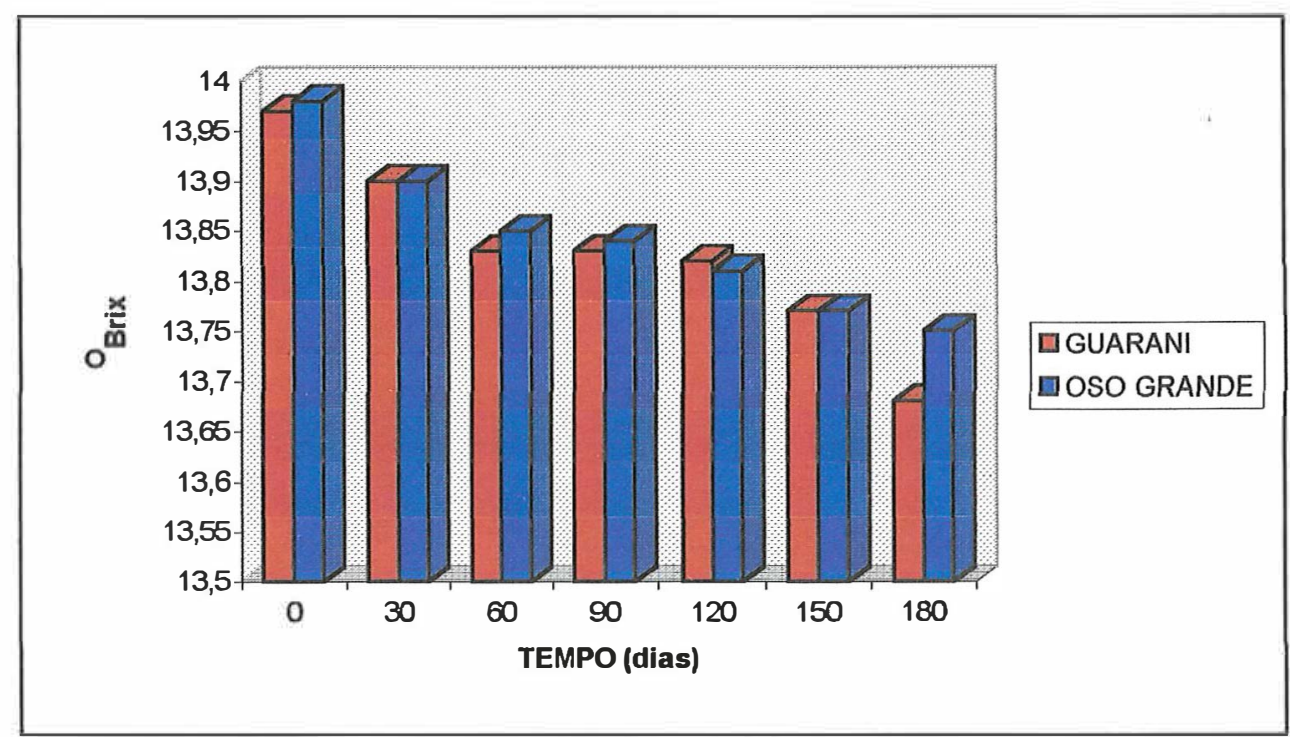

Figura 31 - Teores de sólidos solúveis totais dos néctares dietéticos de morango, em função do tempo de armazenamento 
3 (variedade Guarani) e 4 (variedade Oso Grande). Estes tratamentos, por sua vez, não diferiram estatisticamente dos tratamentos testemunha (T1).

Segundo Alves \& Garcia (1993), a oxidação da vitamina C (ácido ascórbico + ácido dehidroascórbico) também produz compostos com radical carbonila, que por polimerização, produzem pigmentos escuros, os quais são responsáveis pelo escurecimento em sucos que contêm ácido ascórbico. Estes resultados são concordantes com os apresentados pelos néctares comuns e já explicados anteriormente, conforme citação de vários autores.

A perda da coloração dos néctares dietéticos das duas variedades também foi observada ao longo do período de armazenamento (Tabela 20), sendo que até os sessenta dias, a variedade Guarani apresentou néctares com notas médias de coloração regular a boa (nota 6,5 ), enquanto que os néctares da variedade Oso Grande, após os trinta dias de armazenamento, mostraramse com coloração regular (nota 4,44). Pela Figura 32, pode-se dizer, em termos gerais, que a variedade Guarani apresentou néctares com coloração superior aos da Oso Grande.

Os tratamentos 1 e 2, dos néctares da variedade Guarani apresentaram as melhores notas quanto à consistência (Tabela 19). Já para a variedade Oso Grande, o tratamento 3 (que recebeu adição de ácido cítrico) apresentou melhor consistência, não difererindo estatisticamente do tratamento 4. Assim sendo, observa-se que o ácido cítrico foi um agente melhorador de consistência para o néctar da variedade Oso Grande. 
Tabela 19 - Valores médios da análise sensorial dos néctares dietéticos de morango, em função dos tratamentos

\begin{tabular}{c|ccc|ccc}
\hline \multicolumn{7}{c}{ GUARANI } \\
\multicolumn{7}{c}{ CORIEDADES } \\
\hline TRATAMENTOS & COR & CONSIST. & SABOR & COR & CONSIST. & SABOR \\
\hline T1 & $6,13^{\mathrm{B}}$ & $7,58^{\mathrm{A}}$ & $6,13^{\mathrm{B}}$ & $3,75^{\mathrm{B}}$ & $5,92^{\mathrm{B}}$ & $4,63^{\mathrm{C}}$ \\
T2 & $6,88^{\mathrm{A}}$ & $7,42^{\mathrm{A}}$ & $6,83^{\mathrm{A}}$ & $4,96^{\mathrm{A}}$ & $5,88^{\mathrm{B}}$ & $3,83^{\mathrm{D}}$ \\
T3 & $5,88^{\mathrm{B}}$ & $5,79^{\mathrm{B}}$ & $5,79^{\mathrm{B}}$ & $5,58^{\mathrm{A}}$ & $6,71^{\mathrm{A}}$ & $6,79^{\mathrm{A}}$ \\
T4 & - & - & - & $3,25^{\mathrm{B}}$ & $6,21^{\mathrm{AB}}$ & $6,17^{\mathrm{B}}$ \\
\hline F(Tratam.) & $11,03^{\star \star}$ & $5,87^{\star \star}$ & $12,52^{\star \star}$ & $51,47^{\star \star}$ & $6,27^{\star \star}$ & $101,18^{\star \star}$ \\
\hline F(Variedades) & $150,18^{\star \star}$ & $69,06^{\star \star}$ & $97,84^{\star \star}$ & $150,18^{\star \star}$ & $69,06^{\star \star}$ & $97,84^{\star \star}$ \\
\hline
\end{tabular}

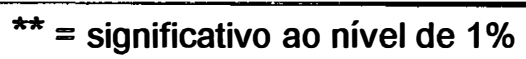

médias com a mesma letra, no sentido vertical, não diferem entre si ao nível de $5 \%$ de significância

Tabela 20 - Valores médios da análise sensorial dos néctares dietéticos de morango, em função do tempo de armazenamento

\section{VARIEDADES}

\begin{tabular}{c|ccc|crc}
\multicolumn{3}{c}{ GUARANI } & \multicolumn{3}{c}{ OSO GRANDE } \\
\hline TEMPO (dias) & COR & CONSIST. & SABOR & COR & CONSIST. & SABOR \\
\hline 30 & $6,91^{\mathrm{A}}$ & $7,87^{\mathrm{A}}$ & $6,88^{\mathrm{A}}$ & $5,50^{\mathrm{A}}$ & $6,91^{\mathrm{A}}$ & $6,16^{\mathrm{A}}$ \\
60 & $6,50^{\mathrm{A}}$ & $7,13^{\mathrm{AB}}$ & $6,29^{\mathrm{A}}$ & $4,44^{\mathrm{B}}$ & $6,15^{\mathrm{B}}$ & $5,25^{\mathrm{B}}$ \\
90 & $5,46^{\mathrm{B}}$ & $6,79^{\mathrm{B}}$ & $5,54^{\mathrm{B}}$ & $3,22^{\mathrm{C}}$ & $5,47^{\mathrm{C}}$ & $4,59^{\mathrm{C}}$ \\
\hline F(TEMPO) & $22,98^{\star \star}$ & $10,37^{\star \star}$ & $19,37^{\star \star}$ & $77,62^{\star \star}$ & $29,33^{\star \star}$ & $44,44^{\star \star}$ \\
\hline
\end{tabular}

** = significativo ao nivel de $1 \%$

médias com a mesma letra, no sentido vertical, não diferem entre si ao nível de $5 \%$ de significância 


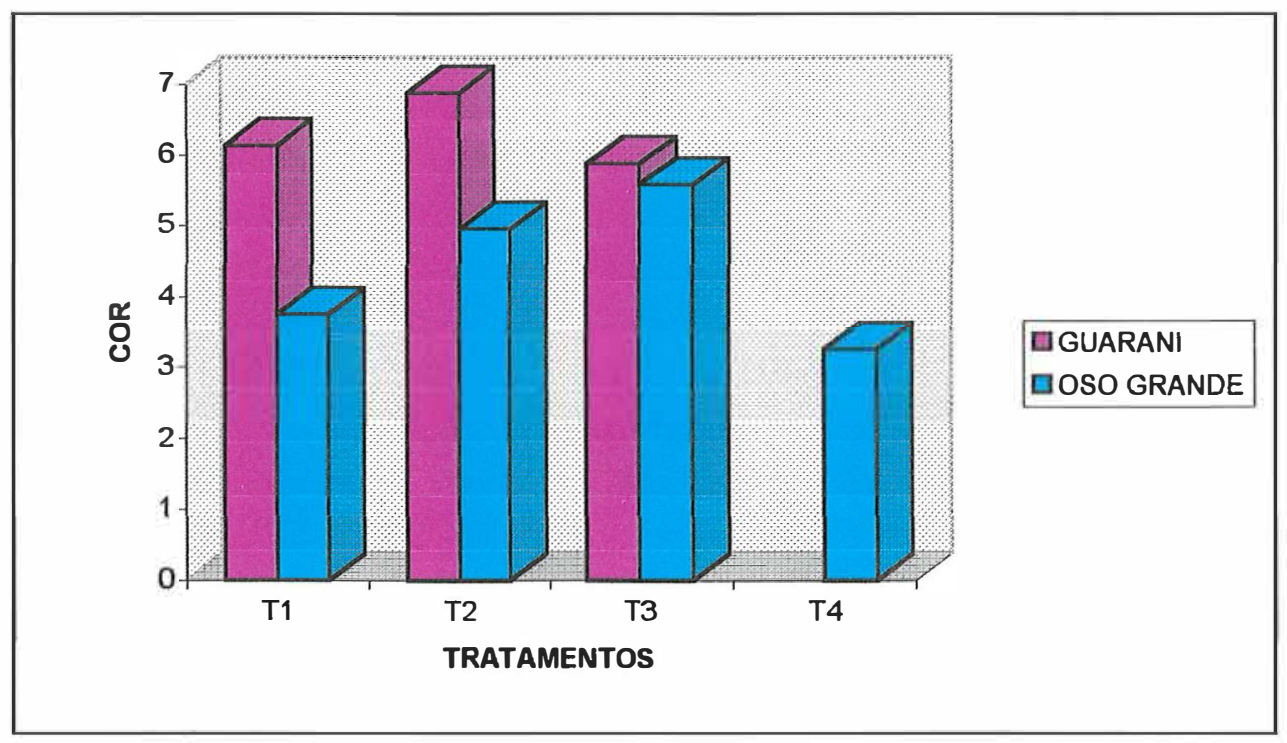

Figura 32 - Valores médios das notas obtidas na avaliação sensorial, quanto à cor dos néctares dietéticos de morango

As notas médias de consistência dos néctares das duas variedades diminuiram em função do tempo de armazenamento (Tabela 20), ou seja, o produto apresentou tendência de tornar-se mais viscoso. Este fato também foi observado por Pilando et al. (1985), que estudaram a composição do suco de morango obtido por frutos amadurecidos, super amadurecidos e contaminados por fungos. Conforme ilustra a Figura 33, observa-se que a variedade Guarani apresentou néctares (T1 e T2) com notas médias de consistência maiores do que a outra variedade.

Observando-se a Tabela 19 e Figura 34, pode-se observar que, para a variedade Guarani, os néctares que apresentaram menores médias de sabor foram aqueles que receberam a adição de ácido ascórbico (T3), conferindo um gosto ácido ao produto. Isso demonstra que a preferência de gosto para a equipe de provadores é de produtos de baixa acidez. Comparando-se com os 
néctares comuns, pode-se observar que os edulcorantes não apresentam o poder de "mascarar" o gosto ácido, como ocorre com a sacarose, já que naqueles produtos foi possível a aplicação do tratamento com adição de ácido cítrico.

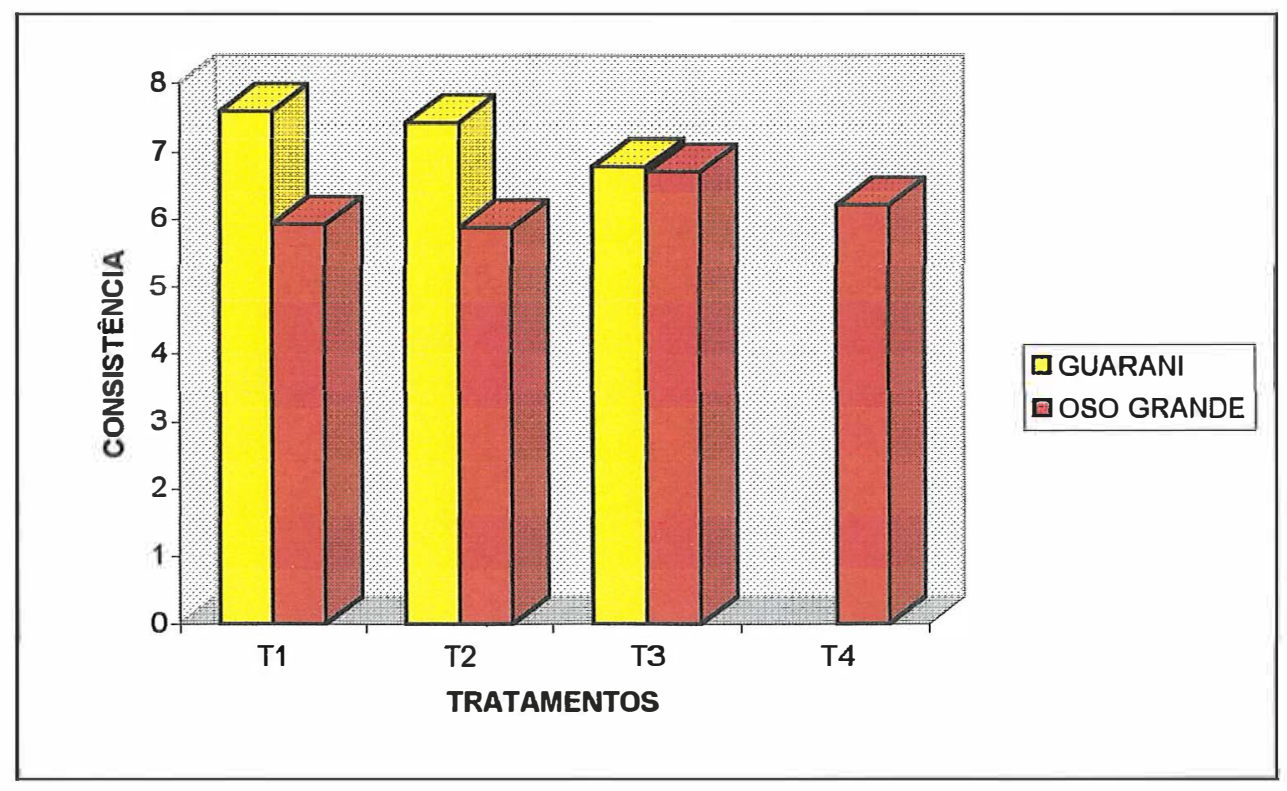

Figura 33 - Valores médios das notas obtidas na avaliação sensorial, quanto à consistência dos néctares dietéticos de morango

Os néctares da variedade Oso Grande com melhores sabores foram aqueles submetidos ao tratamento 3 (Figura 34), diferindo estatisticamente dos demais tratamentos (Tabela 19). O ácido cítrico adicionado ao tratamento 3 conferiu um leve gosto ácido, porém, desejável, já que a matéria-prima da Oso Grande apresentou menores valores de acidez.

Conforme mostra a Tabela 20 , os valores médios das notas para o sabor dos néctares das duas variedades tendem a diminuir com o tempo de 
armazenamento, porém, aos 90 dias, os néctares ainda se mostravam com sabor característico de morango, atestando as boas condições em que se encontravam.

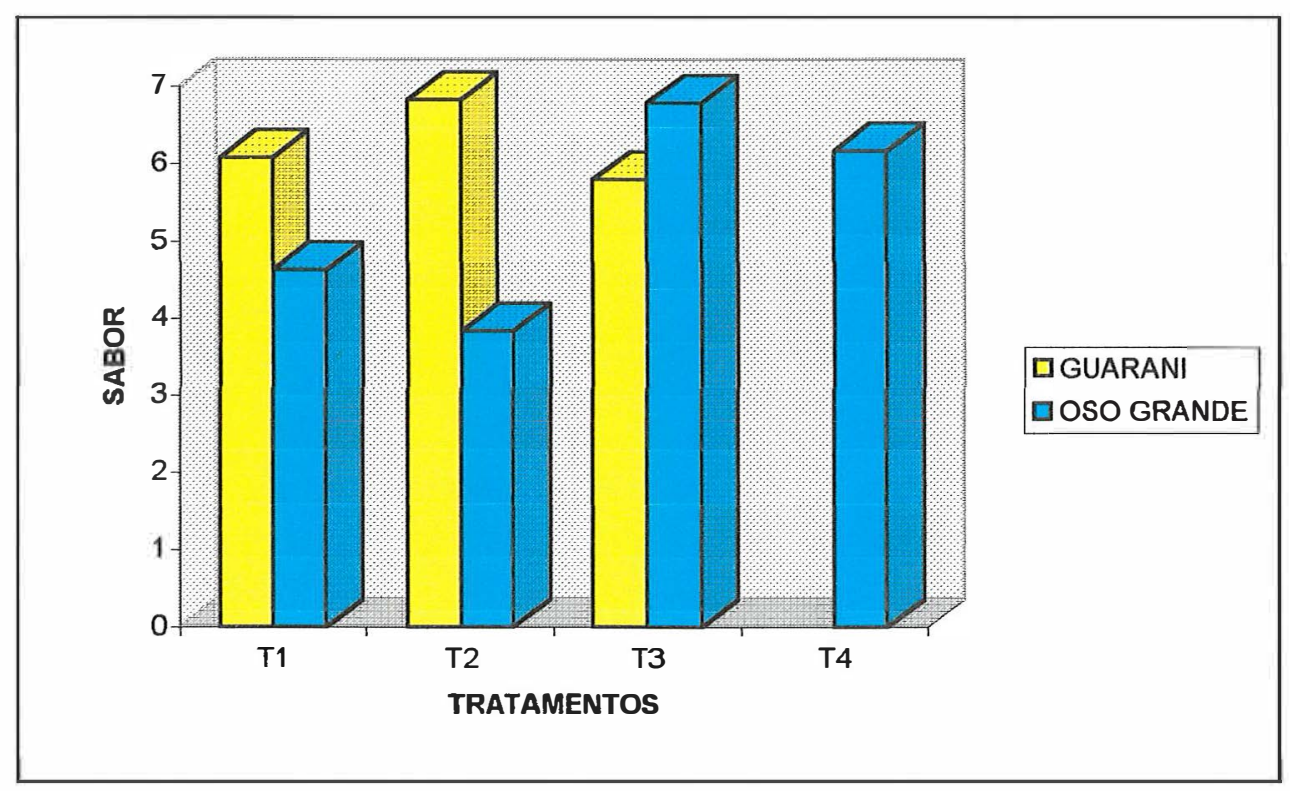

Figura 34 - Valores médios das notas obtidas na avaliação sensorial, quanto ao sabor dos néctares dietéticos de morango

Também é importante ressaltar que a mistura de edulcorantes (esteviosídeo + sorbitol) não apresentou gosto residual nos néctares das duas variedades, bem como ao longo do período de armazenamento, mostrando assim a sua estabilidade e excelente potencial de uso em néctares dietéticos de morango.

Pela observação das Tabelas 19, 20 e Figura 35, pode-se afirmar que a variedade Guarani obteve néctares com notas médias superiores quanto à 
cor, consistência e sabor, quando comparada com os da variedade Oso Grande.

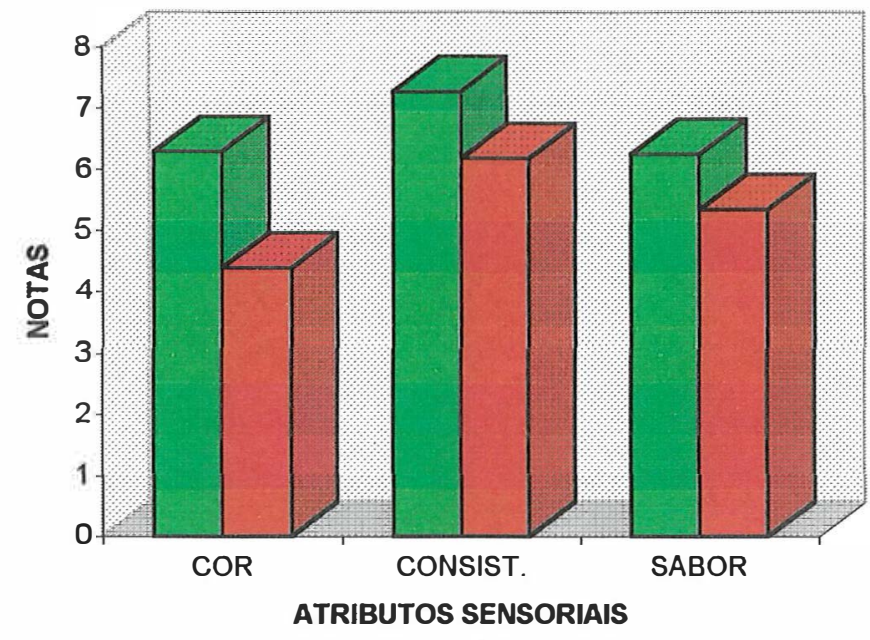

GGUARANI DOSO GRANDE

Figura 35 - Valores médios das notas obtidas na avaliação sensorial, quanto aos atributos de qualidade dos néctares dietéticos de morango 


\section{6 - CONCLUSÕES}

Dentro das condições experimentais em que foi realizado este trabalho, as seguintes conclusões podem ser apresentadas:

- É possível elaborar néctares comum e dietético de morango com as variedades estudadas

- Os néctares comum e dietético de morango das variedades Guarani e Oso Grande apresentaram boa qualidade, sob os pontos de vista químico e organoléptico

- Os néctares comum e dietético de morango da variedade Guarani apresentaram melhor cor, consistência e sabor, em relação à Oso Grande.

- A adição de ácido ascórbico não é um tratamento a ser recomendado para a qualidade dos néctares comum e dietético das duas variedades, especialmente quanto à cor dos produtos.

- A adição de ácido cítrico foi eficaz na preservação da coloração vermelha do néctar comum das duas variedades, bem como para o néctar 
consistência e sabor do néctar dietético da variedade Oso Grande, sendo considerado o melhor tratamento.

- A adição de ácido ascórbico foi efetiva para revitaminação dos néctares.

- As perdas de ácido ascórbico dos néctares comum e dietético das duas variedades, aumentaram com o período de estocagem.

- Mesmo após seis meses de armazenamento, os néctares comum e dietético de morango das duas variedades, que não receberam adição de ácido ascórbico, ainda apresentaram razoáveis teores desta vitamina (cerca de $25 \mathrm{mg} / 100 \mathrm{~g}$ ).

- Os edulcorantes naturais sorbitol e esteviosídeo foram considerados como adoçantes adequados no preparo do néctar dietético.

- Aos noventa dias de armazenamento, os néctares comum e dietético das duas variedades ainda apresentavam sabor característico de morango.

- Finalmente, pode-se dizer que a variedade de morango Guarani é a que apresentou características químicas e organolépticas mais adequadas para o preparo dos néctares comum e dietético. 


\section{REFERÊNCIAS BIBLIOGRÁFICAS}

ABERS, J.E.; WROLSTAD, R.E. Causative factors of colour deterioration in strawberry preserves during processing and storage. Journal of Food Science, v.44, n.1, p.75-81, 1979.

ABREU, R. W. Produto "diet" engorda, diz Instituto. Folha de São Paulo. Cotidiano. São Paulo, 23 maio. 1995.

ABOU-ZAID, M.A.; EL-SAIED, A.A.; ASKAR, A. Technological studies on low calorie apricot nectar. Fruit Processing, v.1, n.4, p.50-51, 1991.

AGGARWAL, P.; BAJAJ, M.; MINHAS, K. S.; SIDHU, J.S. Comparative studies on the suitability of Shane Punjab and Flordarun peach varieties for processing. Journal of Plant Science Research. v.8, n1/4, p.77-80, 1992.

AGUIAR, E.; MORAES, I.R.; LIMA. M.F. Estudos sobre o esteviosideo. Boletim da Sociedade Brasileira de Ciência e Tecnologia de Alimentos, v.21, n.2, p.121-123, 1987.

ALMEIDA, P. G. de. Edulcorantes: a opção diet. Engarrafador Moderno, v.7, n.46. p.57-63, jul./ago. 1996a. 
ALMEIDA, P.G.de $\mathrm{O}$ uso de acidulantes e conservantes em bebidas. Engarrafador Moderno, v.7, n.47, p.41-48, set./out. 1996b.

ALVES, R.M.V.; GARCIA, E.E.C. Embalagem para sucos de frutas. Coletânea do Instituto de Tecnologia de Alimentos, v.23, n.2, p.105122, jul./dez. 1993.

AMOEDO, C. Menos calorias - mais sabor. Saúde, n.166, p.24-36, jul. 1997.

ANDRADE, M.O. de; CAMARGO, R.de. Tecnologia de alimentos e nutrição. In: CAMARGO et al. Tecnologia dos produtos agropecuários. Alimentos. São Paulo: Nobel, 1989. cap.2, p. 9-32.

ARADHITA, A.; GRUPTA, O.P.; DHAWAN, S.S. Evaluation of guava (Psidium guajava) hybrids for making nectar. Haryana Journal of Horticultural Science, v.24, n.2, p.102-109, 1995.

ARAÚJO, J.M.A. Conservadores químicos em alimentos. Boletim da Sociedade Brasileira de Ciência e Tecnologia de Alimentos, v. 24, n.3/4, p.192-210, jul/dez. 1990.

ARÊAS, F. A era diet. Alimentos e Tecnologia, v.7, n.38, p.34-35, 1991.

ASKAR, A.; EL-ASHWAH, F. A.; OMRAN, H.T.; LABIB, A. A. S. Colour stability of tropical nectars and a simple method of its determination. Fruit Processing, v.4, n.1, p.14-20, 1994. 
ASKAR, A.; EL-SAMAHY, S.; IBRAHIM, S.; EL EMARY, Z.H. Reduction of heavy metal content and improving quality of canned mango nectar. Fruit Processing, v.3, n.3, p.84-92, 1993.

ASKAR, A; GHONAIM, S.M. ; ABDEL-FADEEL, M.G.; ALI, A M; ABD-ELGAIED, I.O. Quality assurance of peach pulp and nectar. Fruit Processing, v.6, n.4, p.151-155, 1996.

BAKKER, J.; BRIDLE, P. Strawberry juice color: the effect of sulphur dioxide and EDTA on the stability of anthocyanins. Journal of the Science of Food and Agriculture, v.60, n.5, p.477-481, 1992.

BAKKER, J.; BRIDLE, P.; KOOPMAN, A. Strawberry juice color: the effect of some processing variables on the stability of anthocyanins. Journal of the Science of Food and Agriculture, v.60, n.4, p.471-476, 1992.

BELO, V. Diet e light: a discussão continua. CRN Notícias. n.41, p.4-5, jul./ago./set. 1995.

BENEKE, E. ; FABIAN, F. W. Sorbic acid as a fungistatic agent at different $\mathrm{pH}$ leves for molds isolated from strawberries and tomatoes. Food Technology, v.9, p.486-488, Oct. 1955.

BERBARI, S. A. G.; NOGUEIRA, J. N.; PASSOS, F. Determinações das características químicas e organolépticas de novas variedades de morango para congelamento. Boletim da Sociedade Brasileira de Ciência e Tecnologia de Alimentos, v.28, n.1, p.18-24, jan./jun., 1994. 
BLEINTOTH, E.W.; SALOMÓN, E. A.G.; KATO, K.; SILVA, S.D. da; MORI, E.E.M.; Formulações de néctares de frutas tropicais. Boletim do Instituto de Tecnologia de Alimentos, n.50, p.103-121, mar./abr. 1977.

BOBBIO, F. O.; BOBBIO, P. A. Introdução à química de alimentos. 2.ed. São Paulo: Varela, 1989. 223 p.

BRASIL. Ministério da Agricultura. Complementação de padrões de identidade e qualidade para suco, refresco, néctar e refrigerante de fruta. Brasília, 1974. 33 p.

BRASIL. Ministério da Saúde. Conselho Nacional da Saúde. Resolução $n^{\circ} 4$ de 24 de novembro de 1988. Diário Oficial, Brasília, Seção I, 19/12/88a. p.24.716 -24.723 .

BRASIL. Ministério da Saúde. Comissão Nacional de Normas e Padrões para Alimentos. Resolução $n^{\circ}$ 04/88 do Decreto Lei $n^{\circ} 55.871 / 65$. In: ASSOCIAÇÃO BRASILEIRA DAS INDÚSTRIAS DE ALIMENTOS. Compêndio da Legislação de Alimentos. rev. 4 São Paulo: ABIA, 1988b. v.1A, p. 3.50 .

CARVALHO, P.R.N. Enriquecimento de alimentos: o uso de vitaminas e sais minerais para aumentar o valor nutritivo dos alimentos. Engarrafador Moderno, v.6, n.39, p.54-59, maio/jun. 1995.

CASH, J.N.; SISTRUNK, W.A. The effect of certain chemicals on the color and polysaccharides of strawberry puree. Food Technology, v.24, n.4, p.169-173, 1970. 
CASTELLANE, P.D. Cultura do morangueiro. Jaboticabal: UNESP/FCAVJ, 1990. $14 p$.

CHEFTEL,J.C.;CHEFTEL,H.; BESANÇON, P. Introduccion a la bioquimica y tecnologia de los alimentos. Zaragoza: Acribia, 1987. 404p.

CHITARRA, M.I.F.; CHITARRA, A. B. Pós-colheita de frutos e hortaliças: fisiologia e manuseio. Lavras: Faepe, 1990. 293p.

CLYDESDALE, F.M. Color as a factor in food choice. Critical Reviews in food Science and Nutrition, v.33, n.1, p.83-101, 1993.

COSTA, H.M.da. Os dietéticos e suas propriedades. Nutrição em Pauta, v.3, n.2, p.15, mar./abr. 1995.

DAWSON, R.H. Sensory texting guide for panel evaluation of food and beverages. Food Technology, v.8, n.18, p.25-31, 1964.

DAYRELL, I. Q.; MOURA COSTA, G. C.; BRITO, M. F. Determinação de ácido benzóico em sucos de frutas. Boletim da Sociedade Brasileira de Ciência e Tecnologia de Alimentos, v.26, n.2, p.67-70, jul./dez. 1992.

DIÁZ, M. A.; MATALLANA, G. M. C.; ORZÁEZ, V. M.T. Vitamina C en productos dietéticos. II. Mermeladas. Alimentaria, p.23-26, Abril, 1987. 
DÍEZ, C.; TORIJA, M. E.; CÁMARA, M. M. Influencia del sistema de envasado en la composicion de nectares de piña. Alimentaria, v.33, n.261, p.65-67, Abril, 1995.

DONALD, E. California harvest tour highlights strawberries and their many uses. Food Technology, v.48, n.9, p.128-130, 1994.

DWIVEDI, B. K. Sorbitol and manitol. In: NABORS, L. B.; GELARDI, R. C. Alternative sweeteners. 2.ed. New York : Marcel Dekker, 1986. p.333-348.

DOVILLARD, C.; GUICHARD, E. Comparison by multidimensional analysis of concentrations of volatile compounds in fourteen frozen strawberries varieties. Sciences des Aliments, v.9, n.1, p.53-76, 1989. /Resumo 34 em Food Science Technology Abstracts, v.21, n.9, 1989. p.106/

EL ZOGHBI, M.; SILIHA, H. The effect s of low caloric sweeteners on chemical and physical properties of apricot nectar. Fruit Processing, v.2, n.2, p.19-21, 1992.

EMODI, A. Polyols : chemistry and application. In: LINEBACK, D. R.; INGLETT, G.E. Food carbohydrates. Chicago: AVI Westport, 1982. p.49-61.

ESKIN, M.N.A. Quality and preservation of fruits. Boca Raton: CRC Press, 1991. p.196- 205. 
FERREIRA, V. L. P. Colorimetria em alimentos. Campinas: Instituto de Tecnologia de Alimentos, 1991. 43p.

FILGUEIRA, F. A. R. Manual de olericultura: cultura e comercialização de hortaliças. 2. ed. São Paulo: Ceres, 1982. v.2. 325 p.

FONSECA, H.; NOGUEIRA, J.N. Processamento e conservação de alimentos de origem vegetal - frutas. In: CAMARGO, R. et al. Tecnologia dos produtos agropecuários. Alimentos. São Paulo: Nobel, 1989. cap.7, p.113-124.

FREITAS, N. O avanço dos dietéticos. Alimentos e Tecnologia, v.3, n.16, p.10-14, fev./mar. 1988.

GAVA, A.J. Princípios de tecnologia de alimentos. São Paulo: Nobel, 1978. 284p.

GAVA, A.J. Controvérsia sobre aditivos em alimentos. Alimentos e Tecnologia, v.13, p.28-30, jan./fev. 1987.

GIRARDOT, N. F.; PERYAM, D. R.; SHARPIRO, L. Selection of sensory testing panels. Food Technology, v.4, n6, p.140-143, 1952.

GOFUR, M. A.; SHAFIQUE, M. Z; HELALI, O. H.; IBRAHIM, M.; RAHMAN, M. M.; HAKIM, A. Studies on the formulations and preservation of ripe mango nectar. Journal of Scientific and Industrial Research, v.29, n.3, p.151-162, 1994. 
GOLDONI, J.S.; CEREDA, M.P.; CACLIARI, A.M.; Variação do teor de ácido ascórbico em suco integral durante armazenamento pelo frio. I. Morango (Fragaria sp). Associação Brasileira das Indústrias da Alimentação, n.55, p.24-30, ago. 1981.

HUDSON, M. A.; HOLGATE, M. E. ; GREGORY, M. E.; PICKFORD, E. Home fronzen strawberries. II. Influence of additives in syrup on sensory assessments and texture measurements. Journal of Food Technology, v.10, n.6, p.689-698, 1975.

HUDSON, M. A.; RICKETTS, V. A.; HOLGATE, M. E. Home frozen strawberries. III. Factors affecting sensory assesment. Journal of Food Technology, v.12, n.4, p.421-426, 1977.

Instituto de Economia Agrícola. São Paulo, 1997 (Comunicação Pessoal).

JOHNSON, L.E. Food technology of the antioxand nutrients. Critical Reviews in Food Science and Nutrition, v.35, n.1/2, p.149-159, 1995.

KANESIRO, M.A.B.; FALEIROS, R.R.S.; SARTORI, J.L.; MELO, W.J.; PIZAURO JR. J.M.; BANZATTO, D.A. Efeito de níveis de $\mathbf{N}$ e $P$ sobre algumas características químicas de frutos do tomateiro colhidos em diferentes estágios de maturação. Científica, v.10, n.2, p.233, 1982. 
KANTOR, T. S.; ULYANOVA, T. N.; GOREN'KOVVA, A. N.; VLASOVA,N.V.; POPOVA.; MILAKOVA, E. S. Quality of strawberry hybrids and their processing products. onservnaya i Ovoshchesushil'naya Promyshlennost' n.5, p.25-26, 1984. /Resumo 128 em Food Science Technology Abstracts, v.18, n.10, p.90, 1986/

KWASNIEWSKA, I.; HOSER, A.; BARYLKO -PIKIELNA, N.; ZAWADSKA, L.; SZCZECINSKA, A. Quality of polish domestic fruit juices and nectars. Physical, chemical and sensory caracteristics. Przemysl Fermentacyjny i Owocowo-Warzywny, v.29, n.4, p.21-26, 1985. /Resumo $116 \mathrm{em}$ Food Science Technology Abstracts, v.18, n.8, p.54, 1986/

KHURDIYA, D.S. Composition and quality of nectar prepared from blended pulps of Amrapali and Totapuri mangoes. Journal of Food Science and Technology, v.30, n.2, p.139-140, 1993.

KINGHORN, A. D.; SOERJATO, D. D. Stevioside. In: NABORS , L.B.; GELARDI, R. C. Alternative sweeteners. 2.ed. New York: Marcel Dekker, 1986. p.157- 171.

LEITÃO, M.; DELAZARI, I.; UBOLDI EIROA, M.N.; ARIMA, H.K. Avaliação de sucos, refrigerantes, refrescos, néctares e xaropes em face dos padrões microbiológicos brasileiros. Boletim do Instituto de Tecnologia de Alimentos, n.49, p.75-91, jan./fev. 1977.

LITTLE, A.C. Colorimetry of anthocyanin pigmented products: changes in pigment composition with time. Journal of Food Science, v. 42, n.6, p. 1570-1574, 1977. 
LUKTON, A.; CHINCHESTER, C. O.; MACKINNEY, G. Food Technology, v.10, p.427-432, 1956.

LUNDAHL, D.S.; MC DANIEL, M.R.; WROLSTAD, R.E. Flavor, aroma and compositional changes in strawberry juice concentrate stored at $20^{\circ} \mathrm{C}$. Journal of Food Science, v.54, n.5, p.1255-1258, 1989.

MARKAKIS, P. Stability of anthocyanins in foods. In: MARKAKIS, P. Anthocyanins as food colors. New York: Academic Press, 1982. p.163179.

MARTIN, Z. de; SGARBIERI, V. C.; MENEZES, T. B.; LEITÃO, M. G.; GARRUTI, R. S. Produção de purê de banana acidificado e néctar de banana. Coletânea do Instituto de Tecnologia de Alimentos, v.1, p.273$298,1965 / 66$.

MARTIN, S.L. Selection and training of sensory judges. Food Technology, v.11, n.27, p.22-26, 1973.

MATÉRIAS -primas e aditivos para fabricação de bebidas. Engarrafador Moderno, v.5, n.36, p.20-21, nov./dez. 1994.

MC CANCE, R. A.; WIDDOWSON'S, E. M. The compositions of foods. 5.ed. Cambridge: The Royal Society of Chemistry, 1994. p.308-311.

MENEZES, S.; VIEGAS, S. Dietéticos em alta. Alimentos e Tecnologia, v.6, n..32, p.22-25, fev./mar. 1990. 
MENEZES, S.A. Os naturais do verão. Alimentos e Tecnologia, v.3, n.21, p. 58-59, fev./mar. 1988.

MORAES, M. A.C. Métodos para avaliação sensorial dos alimentos, Campinas: Ed. Unicamp, 1985. 85p.

MORRIS, J.R.; SISTUNK, W. A.; SIMS, C. A.; MAIN, G. L.; WEHUNT, E. J. Cultivar and storage effects on strawberry processing quality. Arkansas Farm Research, v.34, n.5, p.5, 1985. IResumo 29 em Food Science Technology Abstracts, v.19, n.2, p.68, 1987I

MURADIAN, L. B. de A.; PENTEADO, M. de V. C. Edulcorantes em alimentos - uma revisão. Boletim da Sociedade Brasileira de Ciência e Tecnologia de alimentos, v.24, n.1/2, p.1-11, jan.jun. 1990.

MURAYAMA, S. Horticultura. 2. ed. Campinas: Instituto Campineiro de Esnsino Agrícola, 1983. 318p.

NAZÁRIO, G. Aditivos: pior sem eles. Alimentos e Tecnologia. v.3, n.18, p.31-32, fev./mar. 1988.

NOVAES, L.C.C. Conservação pós-colheita do morango através do uso de embalagens plásticas associadas à atmosfera modificada e refrigeração. Jaboticabal. UNESPI Faculdade de Ciências Agrárias e Veterinárias, 1993. 71p. (Monografia) 
OTTO, K. Minimum shelf life of fruit juices. Flüssiges Obst., v.51, n. 11 p. $570 ; 574-80 ; 612-4,1984$. /Resumo 73 em Food Science Technology Technology Abstracts, v.18, n.6, p.56, 1986. p.22-26, 1973/

PADOVANI, M.I. Morango: o delicado e saboroso fruto da integração dos povos. São Paulo: Ícone, 1991. 68p.

PASCHOALINO, J.E.; ZUCCHINI, A.G.; BERNHARDT. S.W.; SILVA, S.D. da; FERREIRA, V.L.P. Estudos sobre avaliação de diferentes variedades locais de morango em relação à sua adequabilidade para congelamento. Coletânea do Instituto de Tecnologia de Alimentos, v.5, p.365-376, $1973 / 74$.

PASCHOALINO, J.E. Congelamento de hortaliças. In: PASCHOALINO, J.E. Processamento de hortaliças. Campinas: ITAL, 1989. p.48-49.

PASSOS, F. A. Caracterização de clones nacionais e introduzidos de morangueiro (Fragaria $x$ ananassa Duch), visando o uso imediato na horticultura e o melhoramento genético. Piracicaba, 1982.116 p. Tese (Mestrado) - Escola Superior de Agricultura "Luiz de Queiroz", Universidade de São Paulo.

PASTOR, M.V.; COSTELL, E.; IZQUIERDO, L.; DURÁN, L. Optimizing acceptability of a high fruit low gum. Journal of Food Science, v.61, n.4, p.852-855, 1996. 
PAVANELLO, J. F. O uso de aditivos em alimentos. Alimentos e Bebidas, v.1, n.7, p.22-24, mar. 1990.

PILANDO, L.S.; WROLSTAD, R.E.; HEATHERBELL, D.A. Influence of fruit composition, maturity and mold contamination on the color and appearance of strawberry wine. Journal of Food Science, v.50, n.4, p.1121-1125, 1985. /Resumo $143 \mathrm{em}$ Food Science Technology Abstracts, v.17, n.12, p.91, 1985/

PRADO, M.E.T. Vida de prateleira e perda de vitamina C durante o armazenamento de um alimento de umidade intermediária obtido da mistura suco-polpa de manga (Mangífera indica L.) - desenvolvimento de modelos matemáticos. Lavras, 1994, 76p. Tese (Mestrado). Escola Superior de Agricultura de Lavras.

RANDI, A.M.; FELIPE, G.M. Detecção de esteviosídeo e substâncias giberelínicas em aquênios de Stevia rebaudiana e efeitos de esteviosídeo em germinação. Ciência e Cultura, v.33, n.4, p.404-410, 1980.

RANGANNA, S. Manual of analysis of fruit and vegetable products. New York: Mc Graw-Hill, 1977. 634p.

RICHARDS, N. S.P. dos S. Avaliação da qualidade das variedades Chandler e Reiko para a obtenção de morango em calda. Piracicaba, 1996. 90 p. Tese (Mestrado) - Escola Superior de Agricultura "Luiz de Queiroz" , Universidade de São Paulo. 
ROCCO, C.S.; SIMON, M.; WEINSCHUTZ, R.; NOGOCEKE, E.; MOREIRA, L.G.; MASSON, M.L.; KOEHLER, H. Avaliação da preferência entre adoçantes comerciais. Boletim da Sociedade Brasileira de Ciência e Tecnolgia de Alimentos, v.25, n.2, p.85-86, jul/dez. 1991.

RODRIGUES, C. Diet e light. Alimentos e Tecnologia, v. 9, n.58, p.55-58, fev./mar. 1995.

RWABAHIZI, S.; WROLSTAD, R.E. Effects of mold contamination and ultrafiltration on the color stability of stawberry juice and concentrate. Journal of Food Science, v.53, n.3. p.857-861, 1988.

SAKAGUCHI, M.; KAN, T. As pesquisas japonesas com Stevia rebaudiana (Bert.) e o esteviosídeo. Ciência e Cultura, v.43, n.2, p.236 -248, fev.1982.

SALOMÓN, E. A. G.; MARTIN, Z. J. de; KATO, K.; SILVA, S.D. da ; MORI, E.E.M.; BLEINROTH, E.W. Formulação de néctares de frutas tropicais. Boletim do Instituto de Tecnologia de Alimentos, n.50, p.103-121, mar./abr.1977.

SALUNKHE, D.K. Sorbic acid as a preservtive for apple juice. Food Technology, v.9, p.590, Nov. 1955.

SHENSHINA, S. V.; ONTILOVA, A. E.; LEVITSKAYA, E. S. Biochemical composition of strawberries, blackcurrants and raspberries. Sadovodstvo Vinogradarstvo i Vinodelie Moldavie, v.38, n.2, p.56-57, 1993. /Resumo 73 em Food Science Technology Abstracts, v.17, n.7, p.91, 1995/ 
SHIROSE, I. Estatística aplicada à experimentação organoléptica, Campinas: Instituto de Tecnologia de Alimentos, 1985. p. 96-111.

SKREDE, G.; WROLSTAD, R.E.; LEA, P.; ENERSEN, G. Color stability of strawberry and blackcurrant syrups. Journal of Food Science, v.57, n.1, p.172-177, 1992.

SOLER,M. P. Industrialização de geléias. Campinas: Instituto de Tecnologia de Alimentos, 1991 (Manual Técnico).

SPAYD, S.E.; MORRIS, J.R. Immature fruits do not affect color stability of strawberry puree. Arkansas Farm Research, v.31, n.3, p.2, May/Jun. 1982.

SPAYD, S.E.; MORRIS, J.R.; ROBERT, C.L. Influence of peroxidase and polyphenol oxidase on the color of puree from machine-harvested strawberries. Journal American Society Horticultural Science, v.10, n.7, p.1070-1073, 1982.

SOUZA, A. F. Absorção de nutrientes por quatro cultivares de morangueiro (Fragaria spp.). Piracicaba, 1976. 144 p. Tese (Doutorado) - Escola Superior de Agricultura "Luiz de Queiroz", Universidade de São Paulo.

SPEERS, R. A.; TUNG, M. A.; JACKMAN, R. L. Prediction of colour deterioration in strawberry juice. Canadian Institute of Food Science and Technology Journal, v.20, n.1, p.1508, 1987. /Resumo $48 \mathrm{em}$ Food Science Technology Abstracts, v.19, n.9, p.84, 1987। 
STANLEY; R. The suitability of soft fruits varieties for processing. Technical Memorandum, Campden food \& Drink Research Association, n. 494, 32p. 1988. /Resumo 19 em Food Science Technology Abstracts, v.21, n.3, p.85, 1989/

STRINGUETTO, K. Dietético ou não, o importante é ser doce. Alimentação e Nutrição, v.11, n.48. p.24-30, mar. 1991.

SUCOS de frutas - um mercado em desenvolvimento. Alimentos e Bebidas, v.1, n.5, p. 48-50, ag./set. 1989.

SZILAGY, K.; MARTON, D. New strawberry varieties "Kortes" and "Hakra's Romata" Kertgazdasag, v.87, n.4. p.49-54, 1987. IResumo 31 em Food Science Technology Abstracts, v.21, n.2, p.73, 1989/

TESSARIOLI NETO, J.T. Influência de cobertura permeável e impermeável sobre o solo e planta na produção do morangueiro (Fragaria $x$ ananassa Duch.). Piracicaba, 1993. 112 p. Tese (Doutorado) - Escola Superior de Agricultura "Luiz de Queiroz", Universidade de São Paulo.

TOLEDO, M.C.de F. Considerações sobre avaliação toxicológica de aditivos para alimentos. Alimentos e Tecnologia, v.2, n.12, p.62-63, nov./dez. 1986.

TRESSLER, D.K.; JOSLYN, M.A. Fruits and vegetable juice processing technology. Chicago: AVI. Westport, 1961. 1028 p. 
UBOLDI EIROA, M.N. Microrganismos deteriorantes de sucos de frutas e medidas de controle. Boletim da Sociedade Brasileira de Ciência e Tecnologia de Alimentos, v.23, n.3/4, p.141-160, jul./dez. 1989.

UYGUN, U.; ACAR, J. Effect of $\mathrm{pH}$, metalic ions and storage temperature on colour and pigment content of cornelian cherry nectar. Fruit Processing, v.5, n.12, p.398-400, 1995.

VOLPI, L. Aditivos alimentares. Alimentação e Nutrição, v.6, n.23. p.40-44, set. 1985 .

VON SHELHORN, M. Efficacy and specificity of chemical food preservatives. Food Technology, v.7, p.97-101, 1953.

WESHE- EBELING, P.; MONTGOMERY,M.W. Strawberry polyphenoloxidase its role in anthocyanin degradation. Journal of Food Science, v.55, n.3, p.731-745, 1990.

WROLSTAD, R.E.; SKREDE, G.; LEA, P.; ENERSEN, G. Influence of sugar on anthocyanin pigment stability in frozen strawberries. Journal of Food Science, v.55, n.4, p.1064-1065; 1072, 1990. 